\title{
New species and new records of terrestrial isopods (Crustacea, Isopoda, Oniscidea) from Brazil
}

\author{
Ivanklin Soares Campos-Filho', Giuseppe Montesanto², Paula Beatriz Araujo ${ }^{3} \&$ Stefano Taiti $^{4}$
}

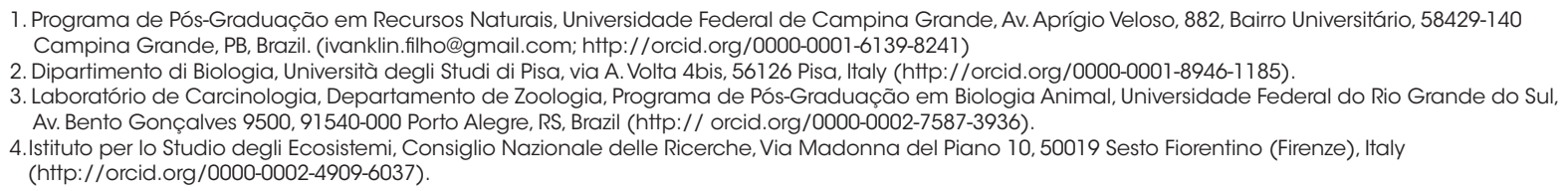

Received 20 January 2017

Accepted 14 July 2017

DOI: $10.1590 / 1678-4766 e 2017034$

\begin{abstract}
A large collection of terrestrial isopods from different Brazilian regions was examined. Two new species of Amazoniscus Lemos de Castro, 1967 (Scleropactidae) are described: A. zimmeri Campos-Filho, Montesanto \& Araujo sp. nov. from the state of Pará and A. schmidti Campos-Filho, Montesanto \& Taiti sp. nov. from the state of Minas Gerais. Pseudotyphloscia alba (Dollfus, 1898) (Philosciidae) is firstly recorded from Brazil. The systematic position of Venezillo tuberosus (Budde-Lund, 1904) is discussed and transferred to Ctenorillo Verhoeff, 1942. Androdeloscia lejeunei (Lemos de Castro \& Souza, 1986) and Diploexochus echinatus Brandt, 1833 from the state of Pará, are redescribed.
\end{abstract}

KEYWORDS. Neotropic, Amazonian tropical rainforest, Atlantic forest.

RESUMO. Novas espécies e novos registros de isópodes terrestres (Crustacea, Isopoda, Oniscidea) do Brasil. Uma grande coleção de isópodes terrestres de diferentes regiões brasileiras foi examinada. Duas novas espécies de Amazoniscus Lemos de Castro, 1967 (Scleropactidae) são descritas: A. zimmeri Campos-Filho, Montesanto \& Araujo sp. proveniente do Estado do Pará e A. schmidti Campos-Filho, Montesanto \& Taiti sp. nov. o Estado de Minas Gerais. Pseudotyphloscia alba (Dollfus, 1898) (Philosciidae) tem o seu primeiro registro para o Brasil. A posição sistemática de Venezillo tuberosus (Budde-Lund, 1904) é discutida e transferida para Ctenorillo Verhoeff, 1942. Androdeloscia lejeunei (Lemos de Castro \& Souza, 1986) e Diploexochus echinatus Brandt, 1833 do Estado do Pará, são redescritas.

PALAVRAS-CHAVE. Neotrópico, Floresta Tropical Amazônica, Mata Atlântica.

To date, ca. 170 species of terrestrial isopods (Oniscidea), distributed in 54 genera and 20 families, are known from Brazil (SOUZA-KuRY, 1998; SCHMALFuss, 2003; ARAujo \& QuADros, 2005; SouZa et al., 2006, 2010, 2011, 2015; Araujo \& Taiti, 2007; Sokolowicz et al., 2008; Magrini et al., 2010; CAmpos-Filho \& Araujo, 2011a,b; CAMPOS-FilHo et al., 2012, 2013a,b, 2014, 2015a,b, 2016; LisBOA et al., 2013; COSTA et al., 2014; CARDOSO et al., 2016).

Recently, many surveys have been conducted through several Brazilian regions, including cave environments, and many specimens have been collected. Some of these species are waiting for identification and/or formal descriptions, in case of new taxa (e.g. MAGRINI et al., 2010; GALlão \& Bichuette, 2015; Silva \& Ferreira, 2015; Fernandes et al., 2016).

A large collection of terrestrial isopods from different Brazilian regions, including Atlantic forest and Amazon rainforest, have been examined and two new species belonging to the family Scleropactidae are recognized. In addition, the examination of specimens of Venezillo tuberosus (Budde-Lund, 1904) from the state of Ceará, allowed us to allocate this species into the genus Ctenorillo Verhoeff, 1942. Also, Androdeloscia lejeunei (Lemos de Castro \& Souza, 1986) and Diploexochus echinatus Brandt, 1833 from the state of Pará, are redescribed.

\section{MATERIAL AND METHODS}

Specimens were stored in $75 \%$ ethanol and identifications were based on morphological characters. The species were illustrated with the aid of a camera lucida mounted on Wild M5 and M20 microscopes. The final illustrations were prepared as in Montesanto (2015, 2016). The SEM micrographs were taken at Centro de Miscroscopia Eletrônica (UFRGS) using a JSM 6060 Scanning Electron Microscope. The coordinates of the noduli laterales were obtained and figured as in VANDEL (1962). The respiratory structures were classified as in FERRARA et al. (1994) and PAOLI et al. (2002). 
The material examined is deposited in the Natural History Museum, Section Zoology 'La Specola', Florence, Italy (MZUF); in the Museu de Zoologia, Universidade de São Paulo, São Paulo, Brazil (MZUSP); and in the Coleção de Crustáceos do Departamento de Zoologia, Universidade Federal do Rio Grande do Sul, Porto Alegre, Brazil (UFRGS).

Abbreviations: APA, Área de Proteção Ambiental (Area of Environmental Protection); CEPLAC, Comissão Executiva de Planejamento de Lavoura Cacaueira (Executive Committee of Cocoa Farming Planning); EE, Estação Ecológica (Ecological Station); FLONA, Floresta Nacional (National Forest); FZBRS: Fundação Zoobotânica do Rio Grande do Sul, Porto Alegre, Brazil; ICZN, International Code of Zoological Nomenclature; MNRJ, Museu Nacional, Universidade Federal do Rio de Janeiro, Rio de Janeiro, Brazil; MPEG, Museu Paraense Emílio Goeldi, Belém, Brazil; UESC, Universidade Estadual de Santa Cruz, Ilhéus, Bahia, Brazil; UFSM, Universidade Federal de Santa Maria, Santa Maria, Brazil; PARNA, Parque Nacional (National Park); PARNAT, Parque Natural (Natural Park); PE: Parque Estadual (State Park); REBIO, Reserva Biológica (Biological Reserve); RPPN, Reserva Particular do Patrimônio Natural (Private Natural Heritage Reserve).

\section{RESULTS}

Trichoniscidae

Miktoniscus Kesselyák, 1930

Miktoniscus medcofi (Van Name, 1940)

Trichoniscus (Miktoniscus) medcofi VAN NAME, 1940: 111, fig. 2.

Trichoniscus (Miktoniscus) humus; MulaIK \& MulaIK, 1942:5, pl. 5, pl. 4, figs 42-52; VAN NAme, 1942:302, fig. 3; Schultz, 1962:47; VANDEL, 1965:375.

Trichoniscus veracrucensis MulaIK, 1960:128, pl. 4, figs 65-70, pl. 5, figs 71-73.

Miktoniscus medcofi; Muchmore, 1957:79; Lemos de Castro, 1953:529, fig. I; 1971:10, fig. 3; VANDEL, 1960:349; SCHULTZ, 1962:47, 1976:36, figs 40-45; Souza-Kury, 1998:668; Araujo \& Bueno, 1998:186; Leistikow \& WÄGELE, 1999:7; SCHMALFuss, 2003:166; CAMPOS-FILHO et al., 2014:363, figs 1-4, 2015b:117.

Miktoniscus alabamensis MuchmoRe, 1964:56; VANDEL, 1965:379, figs 12, 14a-b, 17a-b, 18a-c, 19a-d, 20; PECK, 1970:203.

Miktoniscus ohioensis Muchmore, 1964:51, figs 1-5; Vandel, 1965:373. nec Miktoniscus medcofi; VANDEL, 1965:375, figs 13a-b, 14a-b.

Material examined. BRAZIL, Pará: đ̂, Belém (Campus MPEG), 01²7’09”S, 48²8’35”W, 19.IX.2014, J. T. Lisboa col. (UFRGS 6009).

Previous Brazilian records. Amapá: Serra do Navio (Lemos de CASTro, 1971). Pará: Park of MPEG (Lemos DE CAstro, 1971); Canaã dos Carajás (CAmpos-Filho et al., 2014). Rio de Janeiro: Furnas de Tijuca, Tijuca and Três Rios Road (Freguezia) (Lemos DE CASTRo, 1953); Ilha de Paquetá, Jacarepaguá and Tijuca (Lemos DE CASTRO, 1971). São Paulo: Itanhaém, S. Vicente, Santos and São Paulo (Lemos de CASTro, 1971). Paraná: Água Boa cave, Almirante Tramandaré (CAMPOS-Filho et al., 2015b). Rio Grande do Sul: Porto Alegre (Morro Santana) (Araujo \& BUENO, 1998).
Distribution. Southern and central USA, Mexico and Brazil where it is probably introduced (CAMPOS-FILHO et al., 2014).

\section{Styloniscidae Styloniscus Dana, 1852 Styloniscus spinosus (Patience, 1907)}

(Figs 1-5)

Trichoniscus spinosus PATIEnce, 1907:85, pl. III.

Cordioniscus spinosus: VANDEL, 1933:44.

Styloniscus spinosus; VANDEL, 1952:52, figs 45-47; BARNARD, 1958: 74; ArCangeli, 1961:344; Strouhal, 1961:194; Barnard, 1964:51; Ferrara \& TAITI, 1979:99; TAITI \& Ferrara, 1983:200; Harding \& Sutton, 1985:15; TAITI \& HowARTH, 1996:60; MAGRINI et al., 2010: 216, 2011: 65.

Material examined. BRAZIL, Paraná: 5 ㅇ, Matinhos, São João da Graciosa, Serra da Graciosa, Graciosa road, $25^{\circ} 21^{\prime} 35^{\prime}$ 'S $48^{\circ} 53^{\prime} 01^{\prime \prime} \mathrm{W}, 10 . \mathrm{VIII} .2012$, P. B. Araujo \& B. L. Zimmermann col., not impacted area (UFRGS 5561); $13 \overbrace{}^{\lambda}$, 6 , Matinhos, PARNAT Saint-Hilaire Lang, PR 508 road, 2538'39”'S 48 36'04”'W, 10.VIII.2012, P. B. Araujo \& B. L. Zimmermann col., not impacted area, in leaf litter, in woods (UFRGS 5559). Santa Catarina: $5 \AA$, $5 \circ$, Rancho Queimado,

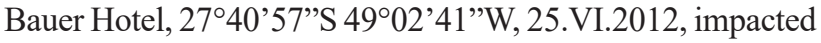
area, in woods and kitchen garden (UFRGS 5570).

Previous Brazilian records. São Paulo: Núcleo Santa Vírginia, Parque das Neblinas and REBIO Paranapiacaba (MAGRINI et al., 2010).

Distribution. Mauritius, Réunion, Madagascar, Hawaii, Brazil (São Paulo, Santa Catarina and Paraná) and greenhouses in Great Britain.

\section{Philosciidae \\ Androdeloscia Leistikow, 1999}

Remarks. To date, Androdeloscia includes 25 Neotropical species recorded from Bolivia, Brazil (Amazonian region), Colombia, Guatemala, Mexico, Peru and Venezuela (Schmalfuss, 2003; Schmidt \& LeISTIKow, 2005; Grangeiro \& Souza, 2006; GrangeIro \& ChristofFERSEN, 2010; López-Orosco et al., 2016). The genus is mainly defined by the reduced body length, antennula with many aesthetascs inserted in one lateral set plus apical pair, antennal flagellum of three articles with apical organ as long as distal article of flagellum, noduli laterales with $\mathrm{d} / \mathrm{c}$ coordinates showing a peak on pereonite 4 , male pleopod 1 exopod rounded and endopod stout bearing a complex distal structure, male pleopod 2 endopod extremely elongated, and male pleopod 5 exopod grooved on medial margin with pectinate scales to accommodate pleopod 2 endopod (LeISTIKow, 1999, 2001; SCHMidT \& LeISTIKow, 2005).

\section{Androdeloscia lejeunei (Lemos de Castro \& Souza, 1986)}

(Figs 6-27)

Prosekia lejeunei Lemos de Castro \& Souza, 1986:432, figs 13-26; SouZA-Kury, 1998:662; LeISTIKOW \& WÄGELE, 1999:22; SCHMALFuSS, 2003:216.

Androdeloscia lejeunei; LeISTIKow, 2001:6. 

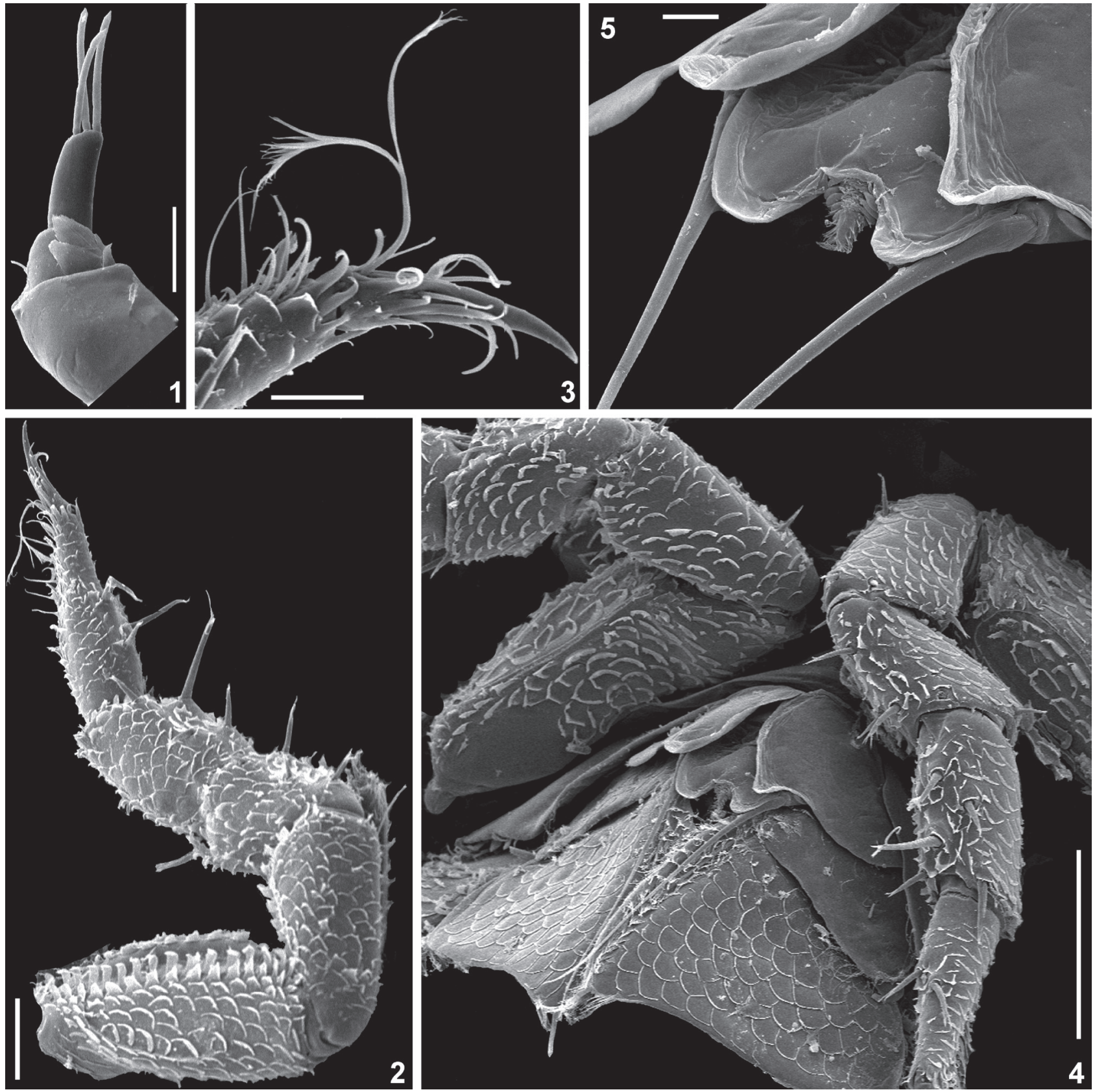

Figs 1-5. Styloniscus spinosus (Patience, 1907), 3: 1, antennula; 2, pereopod 7; 3, pereopod 7 dactylus; 4, pleopods 1-3; 5, genital papilla, distal portion. Scale bars: 1, 3: $20 \mu \mathrm{m} ; 2: 50 \mu \mathrm{m} ; 4: 100 \mu \mathrm{m} ; 5: 10 \mu \mathrm{m}$.

Material examined. BRAZIL, Pará: $2 \widehat{\jmath}, 2+$, Belém, Campus MPEG, 30.IV.2014, J. T. Lisboa col. (MZUF 9645); many $\widehat{O}$ and + , Belém, Campus MPEG, 19.IX.2014, J. T. Lisboa col. (MZUF 9646).

Previous Brazilian records. Pará: Belém, Park of MPEG (Lemos de Castro \& Souza, 1986).

Redescription. Maximum body length: $\widehat{\delta} 2.5 \mathrm{~mm}$; o $3.5 \mathrm{~mm}$. Color light brown; pereon with unpigmented spots on paramedian region, epimera more pigmented; pleon pigmented with some unpigmented spots on pleonites 1-3. Body elongated (Fig. 6), pereonites 1-4 with posterior corners right-angled and posterior margins straight, 5-7 gradually more actue and concave; pleon narrower than pereon with epimera reduced (Fig. 12); dorsum covered with triangular scale-setae (Fig. 7). Noduli laterales very long (Fig. 11), $\mathrm{b} / \mathrm{c}$ and $\mathrm{d} / \mathrm{c}$ coordinates as in Fig. 8. Cephalon (Figs 9, 10) with lateral lobes slightly developed, without frontal line, suprantennal line almost straight; eyes with eight ommatidia. Telson (Fig. 12) triangular, lateral sides almost straight, apex obtuse. Antennula (Fig. 13) of three articles, distal article slightly longer than wide, one set of many aesthetascs inserted subapically plus apical pair. Antenna (Fig. 14) with flagellum of three articles subequal in length, medial and distal articles bearing lateral aesthetascs; apical organ as long as distal flagellar article with two small free sensilla. Mandible (Figs 15, 16) with molar penicil dichotomized, 


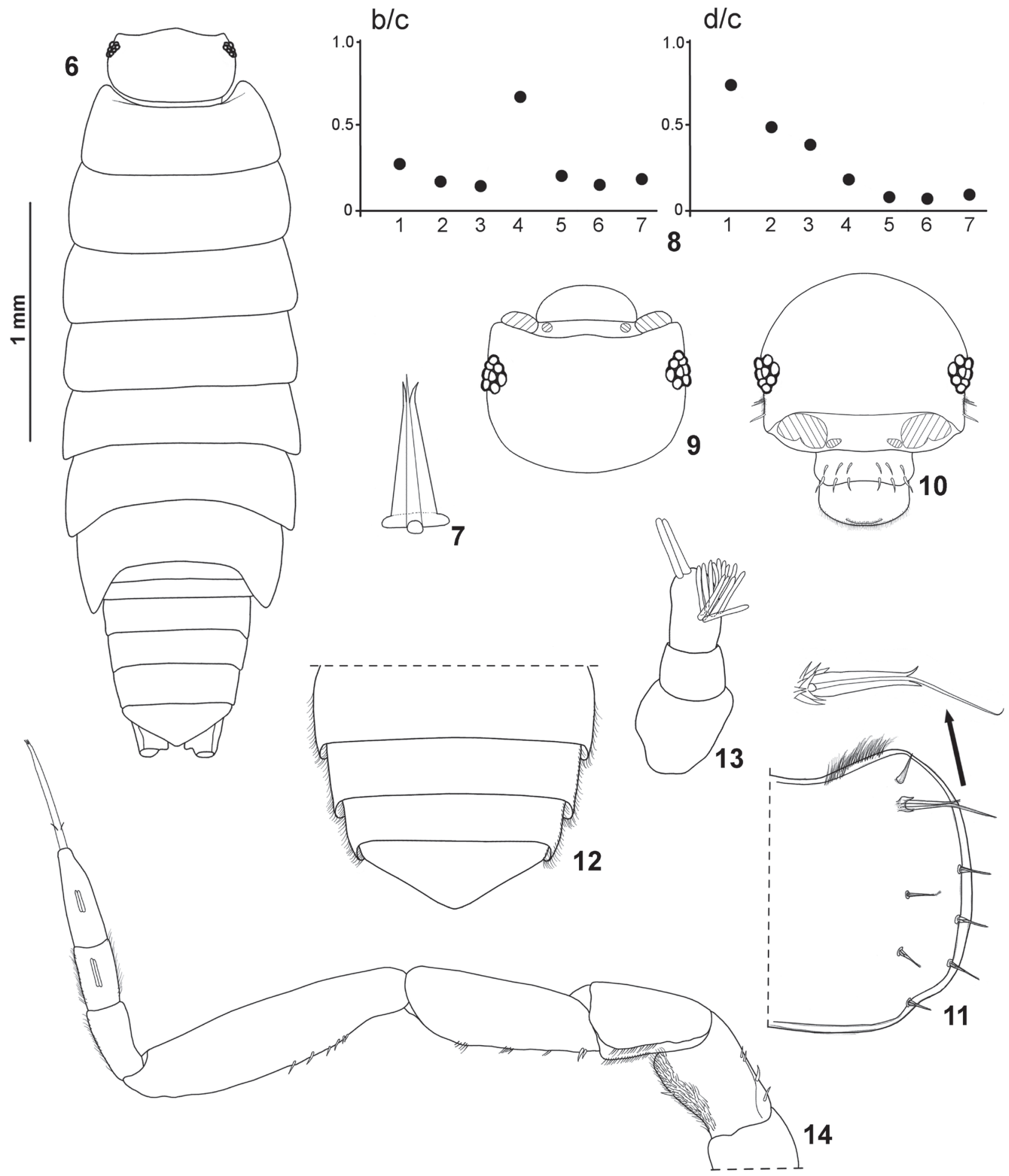

Figs 6-14. Androdeloscia lejeunei (Lemos de Castro \& Souza, 1986), đ: 6, adult specimen, dorsal view; 7, dorsal scale-seta; 8, b/c and d/c coordinates of noduli laterales; cephalon: 9, dorsal view; 10, frontal view; 11, right epimeron of pereonite 1; 12, pleonites 3-5 and telson; 13, antennula; 14, antenna.

consisting of six or seven setae, left mandible with $2+1$ penicils, right with 1+1. Maxillula (Fig. 17) inner endite with two long penicils; outer endite with $4+6$ teeth (four apically cleft) plus accessory tooth. Maxilla (Fig. 18) outer lobe about twice as wide as inner lobe. Maxilliped (Fig. 19) endite with two triangular setae on distal margin, and short penicil near medial corner. Pereopod 1 carpus with antennal grooming brush slightly transverse, distal seta with doubleserrate apex; carpus 1-7 with distal fringe of scales. Pleopod exopods without respiratory areas. Uropod (Fig. 20) grooved on outer margin bearing glandular pores, exopod longer than endopod, endopod inserted proximally. 


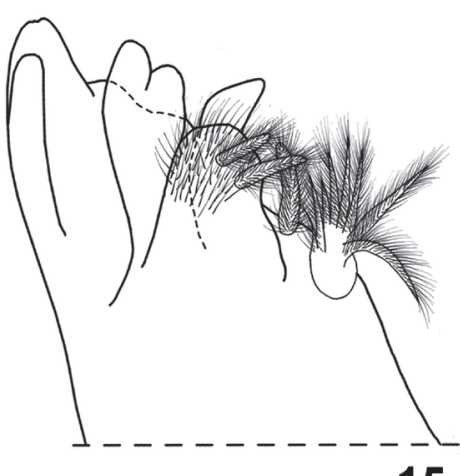

15
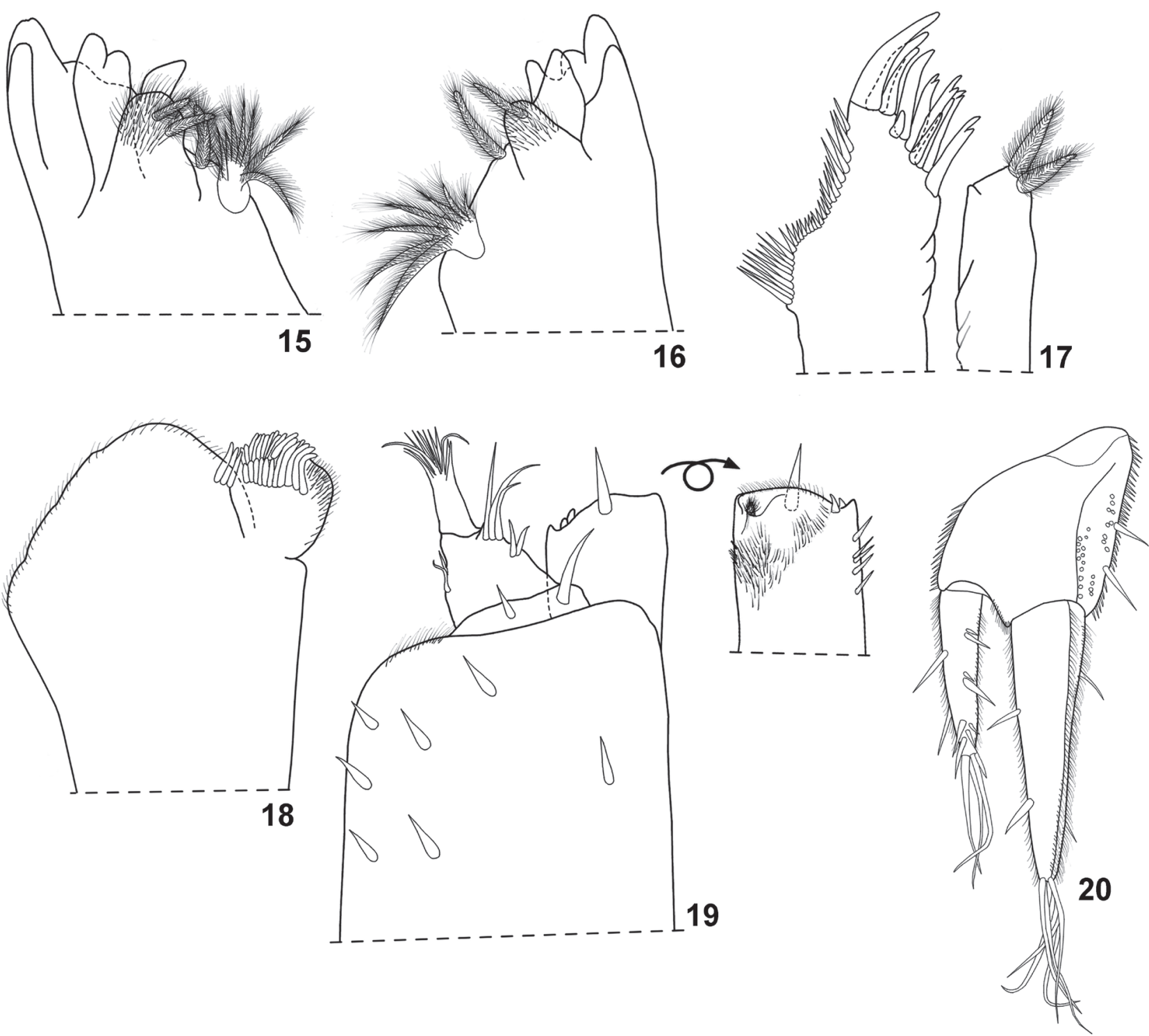

Figs 15-20. Androdeloscia lejeunei (Lemos de Castro \& Souza, 1986), ô: 15, left mandible; 16, right mandible; 17, maxillula; 18, maxilla; 19, maxilliped; 20 , uropod.

Male: pereopods with no sexual modifications (Figs 21, 22). Pleopod 1 (Fig. 23) exopod rounded with outer distal margin slightly concave; endopod with distal part bent outwards with two apical points, inner margin bearing small setae, outer margin bearing strong and short setae. Pleopod 2 (Fig. 24) exopod triangular, outer margin almost straight bearing one subapical seta, distal part slightly bent outwards; endopod flagelliform, about twice as long as exopod. Pleopod 3 and 4 exopods as in Figs 25, 26. Pleopod 5 exopod (Fig. $27)$ triangular, outer margin with subapical seta.

Remarks. Androdeloscia lejeunei is easily distinguished from their congeners by the shape of the male pleopod 1 endopod with a double pointed apex.

Distribution. Androdeloscia lejeunei is recorded from the states of Pará and Tocantins, Brazil.
Atlantoscia Ferrara \& Taiti, 1981 Atlantoscia floridana (Van Name, 1940)

Philoscia floridana VAn Name, 1940:113, fig. 4.

Philoscia sp.; Schultz, 1961:170, 1963:439; DufFey, 1964:249.

Chaetophiloscia paulensis; VANDEL, 1963:74, figs 7, 8, 1968:68, 1977:388; Lemos de Castro, 1971:11.

Philoscia bonita; SCHULTz, 1964:156, figs 1-27.

Atlantoscia alceui; Ferrara \& TAITI, 1981:190, figs 1-4; Lemos de CASTro, 1985:418, figs 1-16.

Ocelloscia floridana; Schultz \& Johnson, 1984:161, figs 4, 5 and 11; JoHNSON, 1986:123, figs 2 and 3.

Atlantoscia floridana; TAITI \& Ferrara, 1991:902, figs 1-15; Araujo et al., 1996:115, figs 11-14 and 64; SouZA-KuRY, 1998:658; LeISTIKOW \& WÄGele, 1999:13; Araujo \& LeistiKow, 1999:117, figs 6-10; Leistikow, 2001:6; Leistikow \& Araujo, 2001:330, fig. 1, plate 1a,b; SChmalfuss, 2003:49; Araujo \& Bond-BucKup, 2004:1, figs 2-6, tables 1-3; Araujo et al., 2004a:952, figs 1-46, tables 1 and 2, 


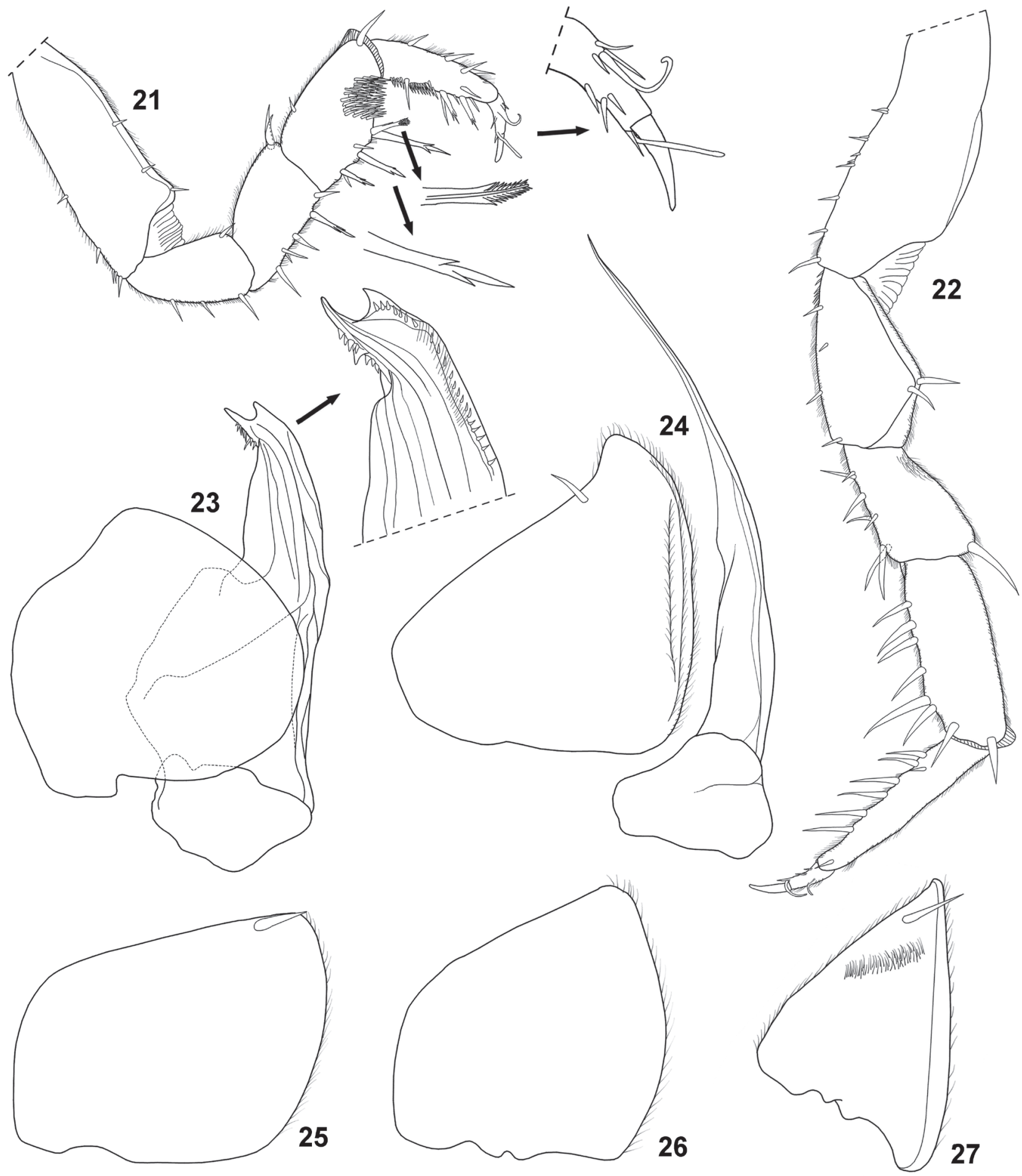

Figs 21-27. Androdeloscia lejeunei (Lemos de Castro \& Souza, 1986), 3 : 21, pereopod 1; 22, pereopod 7; 23, pleopod 1; 24, pleopod 2; 25, pleopod 3 exopod; 26, pleopod 4 exopod; 27, pleopod 5 exopod.

2004b:222, figs 2-30, tables 1-3; AraUjo \& BOND-BUCKUP, 2005:290, figs 3-11, tables 1-5; Lopes et al., 2005:101, table 1; ALMERÃo et al., 2006:474, fig. 4; Quadros \& Araujo, 2007:242, figs 1-3, tables 1,2; 2008:59, figs 1,2, tables 1-5; QuADros et al., 2009:244, figs 1,3, tables 1, 2; QuAdros, 2010:573, fig. 1; ZimMERMANN et al., 2012:712, fig. 1 , table $1 ; 2015 \mathrm{a}: 702$, figs 5,6 , tables $1-3 ; 2015$ b:3, fig. 2, tables 1,2 ; CAMPOS-FilHo et al., 2013a:464, fig. 12a; Wood et al., 2017:4, figs 4-7. nec Philoscia paulensis; Moreira, 1927:194, figs 1-3; MoreIra, 1931:426, fig. 1; Lemos de Castro, 1958a:7; Lemos de Castro, 1976:391.
Material examined. BRAZIL, Bahia: ${ }^{1}$, Barra do Jacuípe, 15.IX.2013, I. S. Campos-Filho \& P. B. Araujo col. (UFRGS 5833); 20, 3 + , Mata de São João, near to Police station, 15.IX.2013, I. S. Campos-Filho \& J. T.

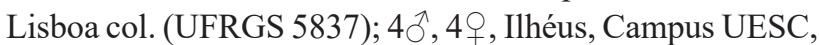
1447’56”'S, 39¹0’20”W, 09.VII.2012, J. T. Lisboa col., in woods, near of bus stop (UFRGS 5694); 2 , , Ilhéus, 
Campus UESC, 30.VII.2012, J. T. Lisboa col., in Theobroma cacao, in Bryophytes (UFRGS 5705); many ổ and + , Itapé, $14^{\circ} 55^{\prime} 08^{\prime}$ 'S, 39²7'43”W, 17.IX.2013, I. S. Campos-Filho \& J. T. Lisboa col. (UFRGS 5829); many ô and + , ItajúItapé, 1501'58'S, 39॰36'15’W, 17.IX.2013, I. S. CamposFilho \& J. T. Lisboa col. (UFRGS 5828). Espírito Santo: many $\delta^{\top}$ and $\odot$, São Mateus, $18^{\circ} 44^{\prime} 53^{\prime \prime}$ S, 39 $9^{\circ} 51^{\prime} 53^{\prime \prime} \mathrm{W}$, 11.III.2014, G. M. Cardoso col. (UFRGS 5899); many ô and $\circ$, Linhares, $19^{\circ} 25^{\prime} 45^{\prime} \mathrm{S}, 40^{\circ} 05^{\prime} 12^{\prime \prime} \mathrm{W}, 11 . \mathrm{III} .2014$, G. M. Cardoso col. (UFRGS 5902); $\hat{\jmath}, 3$ 옹, Santa Tereza, 1956'29”'S, 40³4'56”'W, 12.III.2014, G. M. Cardoso col. (UFRGS 5903); ’’, Santa Tereza, 1956'29”S, 40³4'56”'W, 12.III.2014, G. M. Cardoso col. (UFRGS 5913); many o and 9 , Cariacica, $20^{\circ} 14^{\prime} 29^{\prime \prime} \mathrm{S}, 40^{\circ} 25^{\prime} 02^{\prime \prime} \mathrm{W}, 13 . \mathrm{III} .2014$, G. M. Cardoso col. (UFRGS 5901); ${ }^{2}$, Domingos Martins, 2022'32”S, 40³5'33”'W, 13.III.2014, G. M. Cardoso col. (UFRGS 5918). Minas Gerais: $2 \hat{\jmath}, 5 \circ$, Haras Pousada Raíz Mineira, 12.VI.2013, I. S. Campos-Filho \& G. M.

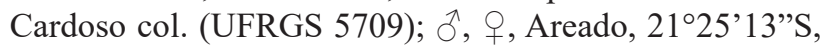
4609'43”'W, 11.VI.2013, I. S. Campos-Filho \& G. M. Cardoso col., in coffee monoculture, near of Furnas dike (UFRGS 5706); 30^, 69, 1 manca, Campanha, 2149'52”S, $45^{\circ} 35^{\prime} 32^{\prime \prime}$ W, 07.VI.2013, at 932 meters, I. S. CamposFilho \& G. M. Cardoso col., in bromeliads (UFRGS 5608); ․ Heliodora, 21 ${ }^{\circ} 52^{\prime} 52^{\prime \prime} \mathrm{S}, 45^{\circ} 33^{\prime} 10^{\prime \prime} \mathrm{W}, 07 . \mathrm{VI} .2013$, I. S. Campos-Filho \& G. M. Cardoso col. (UFRGS 5681); many $\widehat{O}$ and 9 , Heliodora, 07.VI.2013, I. S. Campos-Filho \& G. M. Cardoso col. (UFRGS 5742); ㅇ, Pedralva, 22 ${ }^{\circ} 12^{\prime} 03^{\prime \prime}$, 45'25'17'W, 07.VI.2013, I. S. Campos-Filho \& G. M. Cardoso col. (UFRGS 5682); ㅇ, Itamonte, $22^{\circ} 20^{\prime} 44^{\prime \prime}$, 4448'52”W, 07.III.2014, G. M. Cardoso col. (UFRGS 5906). Rio de Janeiro: ${ }^{\wedge}, 4+$, PARNA Itatiaia, $22^{\circ} 27^{\prime} 45^{\prime \prime}$, $44^{\circ} 35^{\prime} 32^{\prime \prime} \mathrm{W}$, at 568 meters, 09.VI.2013, I. S. CamposFilho \& G. M. Cardoso col., in woods (UFRGS 5698); many ${ }^{\lambda}$ and ㅇ, Buzios, Praia João Fernandez, 22 ${ }^{\circ} 44^{\prime} 21^{\prime \prime}$, 4152'29”'W, 08.III.2014, G. M. Cardoso col. (UFRGS 5895); $5{ }^{\wedge}, 3$ 우, Buzios, Praia da Tartaruga, $22^{\circ} 45^{\prime} 20^{\prime}$ 'S, 41 $54^{\prime}$ '05”'W, 08.III.2013, G. M. Cardoso col. (UFRGS 5896); many ơ and $\odot$, Buzios, Praia do Peró, $22^{\circ} 52^{\prime} 01^{\prime \prime}$ S, 41 ${ }^{\circ} 59^{\prime} 06$ ”'W, 08.III.2013, G. M. Cardoso col. (UFRGS 5897); many ${ }^{\lambda}$ and $\odot$, Cabo Frio, Praia das Conchas, 22 $2^{\circ} 52^{\prime} 20^{\prime \prime}$, 41 ${ }^{\circ} 58^{\prime} 59$ 'W, 08.III.2013, G. M. Cardoso col. (UFRGS 5900); o, 79 , PARNA Itatiaia, $22^{\circ} 45^{\prime} 43^{\prime \prime} \mathrm{S}, 44^{\circ} 37^{\prime} 11^{\prime \prime} \mathrm{W}$, at 1158 meters, 09.VI.2013, I. S. Campos-Filho \& G. M. Cardoso col., in Atlantic forest (UFRGS 5698); 3 \% , Saquarema, 22 ${ }^{\circ} 55^{\prime} 28^{\prime}$ 'S, 42 26'24”W, 08.III.2014, G. M. Cardoso col. (UFRGS 5898). São Paulo: $3{ }^{\lambda}, 4+1$, 1 juvenile, Mongaguá, 2405'04'S, 46³6'37'W, 03.XII.2013, G. M. Cardoso col.

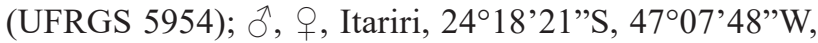
03.XII.2013, I. S. Campos-Filho col. (UFRGS 5955); 50, 6우, Iguape, $24^{\circ} 34^{\prime} 10^{\prime}$ 'S $4^{\circ} 7^{\circ} 32^{\prime} 55^{\prime}$ 'W, 03.XII.2013, I. S. Campos-Filho col. (UFRGS 5960); ${ }^{\lambda}$,,,+ 1 juvenile, Iguape, $24^{\circ} 42^{\prime} 48^{\prime}$ 'S, 47 47'09”'W, 02.XII.2013, I. S. Campos-Filho col. (UFRGS 5956); 今^, 2 ㅇ, 1 juvenile, Iguape, $24^{\circ} 45^{\prime} 48^{\prime \prime}$, 47³2'47'W, 03.XII.2013, I. S. Campos-Filho col. (UFRGS 5958); $0^{\Uparrow}, 2$, 4 juveniles, Itapoá, $25^{\circ} 08^{\prime} 58^{\prime \prime} \mathrm{S}, 48^{\circ} 38^{\prime} 20^{\prime \prime} \mathrm{W}$, 01.XII.2013, I. S. Campos-Filho col. (UFRGS 5961); $3 \hat{0}$,
4ㅇ, 4 juveniles, Guaraqueçaba, $25^{\circ} 16^{\prime} 46^{\prime \prime} \mathrm{S}, 48^{\circ} 43^{\prime} 41^{\prime \prime} \mathrm{W}$, 02.XII.2013, I. S. Campos-Filho col. (UFRGS 5952); 2 , , 3 juveniles, Guaraqueçaba, 02.XII.2013, I. S. Campos-Filho col. (UFRGS 5963); many $\hat{O}$,,+ Imbituba, Morro Mirim, $28^{\circ} 14^{\prime} 40^{\prime \prime S}, 48^{\circ} 41^{\prime} 53^{\prime \prime}$ W, 30.VI.2013, I. S. Campos-Filho col. (UFRGS 5953). Mato Grosso do Sul: $7 \delta^{\lambda}, 6$ 어, Jardim, RPPN Rio da Prata, $21^{\circ} 27^{\prime} 41^{\prime \prime}$ S, 56 $26^{\circ} 23^{\prime \prime} \mathrm{W}, 13 . X I .2014$, G. M. Cardoso col. (UFRGS 6010). Paraná: $2 \hat{\jmath}, 2$, 2 juveniles, Morretes, $25^{\circ} 22^{\prime} \mathrm{S}, 48^{\circ} 51^{\prime} 15^{\prime}$ 'W, 02.XII.2013, I. S. Campos-Filho col. (UFRGS 5951); 2 , , Morretes, $25^{\circ} 26^{\prime} 46^{\prime}$ 'S $48^{\circ} 46^{\prime} 05^{\prime \prime} \mathrm{W}, 10 . \mathrm{VIII} / .012$, P. B. Araujo \& B. L. Zimmermann col., in bulding, near to the road (UFRGS 5536); many ${ }^{\wedge}$ and $\circ$, Morretes, $25^{\circ} 31^{\prime} 35^{\prime \prime} \mathrm{S}, 48^{\circ} 47^{\prime} 16^{\prime \prime} \mathrm{W}$, 01.XII.2013, I. S. Campos-Filho col. (UFRGS 5959); $\partial^{\lambda}, 2$, Matinhos, PARNAT Saint-Hilaire, PR 508 road, 2538'39"S, 4836'04'W, 10.VIII.2012, P. B. Araujo \& B. L. Zimmermann col., in leaf litter and woods (UFRGS 5558); 60, 10우, 1

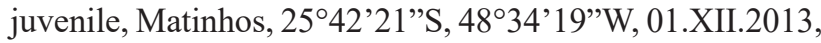
I. S. Campos-Filho col. (UFRGS 5957); $\widehat{A}$, Lapa, PE do Monge, 2546'55”S, 4941'49"W, 11.VIII.2012, P. B. Araujo \& B. L. Zimmermann col., area with restaurants, in woods

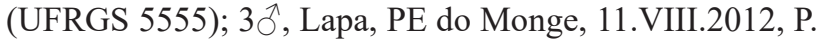
B. Araujo \& B. L. Zimmermann col. (UFRGS 5619); 우, Curitiba, $26^{\circ} 26^{\prime} \mathrm{S} 49^{\circ} 14^{\prime} \mathrm{W}, 13$.VIII.2012, P. B. Araujo \& B. L. Zimmermann col. (UFRGS 5558). Santa Catarina:

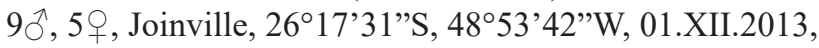
I. S. Campos-Filho col. (UFRGS 5962); 6ðึ, 5ㅇ, Corupá, $26^{\circ} 25^{\prime} 23^{\prime \prime} \mathrm{S}, 49^{\circ} 14^{\prime} 46^{\prime}$ 'W, 27.VI.2012, P. B. Araujo \& B. L. Zimmermann col., under Palm tree leaves (UFRGS 5366); 5 , Blumenau, Parque das Nascentes, $27^{\circ} 03^{\prime} 27^{\prime \prime} \mathrm{S}$, $49^{\circ} 05^{\prime} 10^{\prime}$ 'W, 27.VI.2012, P. B. Araujo \& B. L. Zimmermann col., open vegetation cover, in bromeliads (UFRGS 5588); 9 $\widehat{\jmath}, 11$, , Blumenau, Parque das Nascentes, 27.VI.2012, P. B. Araujo \& B. L. Zimmermann col. (UFRGS 5618); , Rancho Queimado, Bauer Hotel, 2740'57'S, 49 $02^{\prime} 41^{\prime \prime} \mathrm{W}$, 25.VI.2012, P. B. Araujo \& B. L. Zimmermann col., site with many roots, in bromeliads (UFRGS 5574); $\lambda$,, , Rancho Queimado, Bauer Hotel, 25.VI.2012, P. B. Araujo \& B. L. Zimmermann col. (UFRGS 5616); $\hat{\jmath}$,, , Santa Rosa de Lima, 2759'17'S, 4906'45'W, 25.VI.2012, P. B. Araujo $\&$ B. L. Zimmermann col., near of pasture, in woods, dense vegetation cover, many roots (UFRGS 5579); 2 , Santa Rosa de Lima, 2759'33”'S, 4906'48”W, 25.VI.2012, P. B. Araujo \& B. L. Zimmermann col. (UFRGS 5613); $2 \widehat{\text {, }}$ 2+, Santa Rosa de Lima, 25.VI.2012, P. B. Araujo \& B. L. Zimmermann col. (UFRGS 5679); $2 \hat{\jmath}, 3 \circ$, Orleans, Real Nob Hotel, $28^{\circ} 21^{\prime} 17^{\prime}$ 'S, 49¹6'29”'W, 24.VI.2012, P. B. Araujo \& B. L. Zimmermann col., litter with many roots, in bromeliads (UFRGS 5563). Rio Grande do Sul: many $\delta$ and $q$, Rio da Várzea, abandoned house, 26.VII.2013, G. M. Cardoso col. (UFRGS 5733).

Previous Brazilian records. Pará: Park of MPEG (Lemos de Castro, 1985). Rio Grande do Norte: Macaíba (Lemos de Castro, 1985). Paraíba: João Pessoa (Lemos de Castro, 1985). Pernambuco: Moreno (Lemos de Castro, 1985). Sergipe: Santo Amaro das Brotas (CAMPos-Filho et al., 2013a). Bahia: Abrolhos Archipelagous and Salvador 
(Lemos de Castro, 1985); REBIO de Una (CAmpos-Filho et al., 2013a). Minas Gerais: Lagoa Santa and Leopoldina (Lemos de Castro, 1985); Barão de Cocais, Lagoa Santa, Manhuaçu and Santana do Riacho (CAMPos-FilHo et al., 2013a); Varginha (Zimmermann et al., 2015b). Espírito Santo: Santa Cruz and Santa Tereza (Lemos De CASTRo, 1985); Guarapari (PE Paulo César Vinha), Ibitirama, Meaípe and Santa Leopoldina (CAMPos-FilHo et al., 2013a). Rio de Janeiro: Restinga de Jacarepaguá and Petrópolis (VANDEL, 1963); Maringá, Ilha de Itacuruçá, PARNA Serra dos Órgãos, Planalto do Itatiaia and REBIO de Jacarepaguá (Lemos DE CASTRo, 1985). São Paulo: Baruerí, Jacareí and Ubatuba (Lemos DE CASTRO, 1985); Campinas (PE Emílio José Salim), Iguape, Ilha do Cardoso, Microbacia do Rio Quilombo, Miracatu, Peruíbe (EE Juréia Itatins), PE Cantareira, PE Jacupiranga and São Paulo (CAmpos-Filho et al., 2013a). Paraná: Paranaguá (Lemos de Castro, 1985); Curitiba, Morretes (PE Pau Oco) and Toledo (CAmpos-Filho et al., 2013a); Curitiba and Foz do Iguaçu (Zimmermann et al., 2015b). Santa Catarina: Florianópolis, Itajaí and Seara (CAMPos-FiLho et al., 2013a); Blumenau, Corupá, Orleans, Rio Fortuna and São João Batista (Zimmermann et al., 2015b). Rio Grande do Sul: Guaíba (Lemos de CASTRo, 1985); REBIO Lami, Porto Alegre (ARAujo \& Bond, 2004); Barra do Ouro and Rincão dos Kroeff (LoPEs et al., 2005); PE Itapuã, Porto Alegre (Almerão et al., 2006; Quadros \& Araujo, 2007, 2008; Quadros et al., 2009); Morro Santana and Belém Novo, Porto Alegre (Zimmermann et al., 2012, 2015a); Arroio do Sal, Arroio Teixeira, Barra do Ouro, Dom Pedro de Alcântra, Itapeva (Torres), Maquiné, Morrinhos do Sul, Morro Azul, Porto Alegre (REBIO Lami), Rincão dos Kroeff, Rondinha, São Francisco de Paula, Terra de Areia and Três Passos (CAmpos-Filho et al., 2013a); Arroio do Sal, Barra do Ribeiro, Mariana Pimentel, Mostardas and Torres (ZimMERMANn et al., 2015b).

Distribution. Coastal regions of Florida, Brazil, Argentina, Ascension and St. Helena Island (Schmalfuss 2003).

\section{Atlantoscia ituberasensis Campos-Filho, Lisboa \& Araujo, 2013}

Atlantoscia ituberasensis CAMPos-FILHO et al., 2013a:466, figs 1-5, 12c; ZimMERMANN et al., 2015a:702, figs 5, 6, tables 1-3.

Material examined. BRAZIL, Bahia: †, Camacã, BR-101 road, 15²8’01'S, 39²6’33”W, 20.IX.2013, I. S. Campos-Filho \& J. T. Lisboa col. (UFRGS 5834).

Previous Brazilian records. Bahia: Ituberá (CAMPOSFiLho et al., 2013a); Ituberá and Santa Cruz da Vitória (ZimMERMANN et al., 2015a).

Distribution. This species is recorded only from the state of Bahia, Brazil.

\section{Atlantoscia rubromarginata Araujo \& Leistikow, 1999}

Atlantoscia rubromarginata Araujo \& Leistikow, 1999:110, figs 1-5; Leistikow, 2001:6; Schmalfuss, 2003:49; CAmpos-Filho et al., 2013a:466, fig. 12b; LisboA et al., 2013:394, fig. 1b; Zimmermann et al., 2015a:702, figs 5, 6, tables 1-3; 2015b:3, table 1 .

Material examined. BRAZIL, Pará: many $\widehat{\partial}$ and

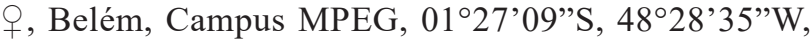
19.IX.2014, J. T. Lisboa col. (UFRGS 6007). Bahia: 3 , Travessão, APA Camamu, 1408'31'S, 39¹7'29”W, 18.IX.2013, I. S. Campos-Filho \& J. T. Lisboa col. (UFRGS

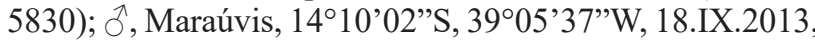
I. S. Campos-Filho \& J. T. Lisboa col. (UFRGS 5826); $\widehat{O}$, , +, Itabuna, BR-101 road, 1452'52”S, 39¹6'57’W, 20.IX.2013, I. S. Campos-Filho \& J. T. Lisboa col. (UFRGS 5836); many $\sigma^{\top}$ and + , Una, Ilha do Desejo, $15^{\circ} 05^{\prime} 02^{\prime}$ 'S, 38 $59^{\circ} 57^{\prime \prime} \mathrm{W}$, 19.IX.2013, I. S. Campos-Filho \& J. T. Lisboa col. (UFRGS

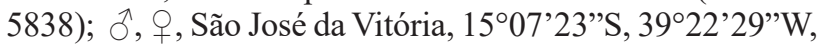
20.IX.2013, I. S. Campos-Filho \& J. T. Lisboa col. (UFRGS 5832); $\widehat{\partial}$, o , Una, REBIO Una, $15^{\circ} 10^{\prime} 08^{\prime \prime} \mathrm{S}, 39^{\circ} 00^{\prime} 03^{\prime \prime} \mathrm{W}$, 19.IX.2013, I. S. Campos-Filho \& J. T. Lisboa col. (UFRGS 5835); Oे, Canavieiras, $15^{\circ} 29^{\prime} 01^{\prime \prime} \mathrm{S}, 38^{\circ} 59^{\prime} 48^{\prime \prime} \mathrm{W}, 19 . \mathrm{IX} .2013$, I. S. Campos-Filho \& J. T. Lisboa col. (UFRGS 5831).

Previous Brazilian records. Alagoas: REBIO Pedra Talhada, Quebrangulo (CAMPos-FilHo et al., 2013a). Sergipe: Areia Branca (PARNA Serra Itabaiana) and Santa Luzia do Itanhy (CAMPos-FiLho et al., 2013a). Bahia: Camacan (RPPN Serra Bonita), Canavieiras, Ibicaraí, Ilhéus (CEPLAC), Ituberá, Porto Seguro (PARNA Pau Brasil), Salvador and Una (CAmpos-Filho et al., 2013a); Ilhéus and Santa Cruz da Vitória (ZimMERMANN et al., 2015a, 2015b).

Distribution. States of Alagoas, Sergipe, Pará and Bahia, northeastern Brazil.

\section{Benthana Budde-Lund, 1908 Benthana longipenis Lemos de Castro, 1958}

Benthana longipenis LEMOS DE CASTRO, 1958b:109, figs 69-77; SOUZA-KuRY, 1998:659; Leistikow \& WäGele, 1999:14; Schmalfuss, 2003:53; CAMPos-FilHo et al., 2015a:32, figs 19, 20, 25b.

Material examined. BRAZIL, Minas Gerais: many $\widehat{\delta}$ and $\bigcirc$, Eloi Mendes, G. M. Cardoso col. (MZUF 9647).

Previous Brazilian records. São Paulo: Lageado, Serra da Bocaina (Lemos DE CASTRO, 1958b). Minas Gerais: Caeté (Gruta AP-65 cave), Itamonte, Liberdade, Lima Duarte (PE do Ibitipoca) (CAmpos-Filho et al., 2015a). Rio de Janeiro: Petrópolis and Planalto do Itatiaia (Agulhas Negras, Macieiras, Pedra da Tartaruga, Repouso Itatiaia) (CAMPosFilho et al., 2015a). São Paulo: Lajeado (Serra da Bocaina), São Bento do Sapucaí, São José do Barreiro (PARNA Serra da Bocaina), and Wenceslau Braz (CAMPos-FilHo et al., 2015a). Rio Grande do Sul: Erechim (CAMPos-FiLHo et al., 2015a). Distribution. States of Minas Gerais, Rio de Janeiro, São Paulo and Rio Grande do Sul, Brazil.

\section{Benthana tupinamba Campos-Filho, Taiti \& Araujo, 2015}

Benthana tupinamba CAMPos-FilHo et al., 2015a:61, figs 39, 40, 43.

Material examined. BRAZIL, Bahia: 7ð, 2 , Ilhéus, UESC, 144ㄱ'45”S, 39¹0’14”W, 25.VII.2013, J. T. Lisboa col. (MZUF 9648). 
Previous Brazilian records. Bahia: Ilhéus (CAMPosFILHO et al., 2015a)

Distribution. This species is known only from the type locality: Ilhéus, Bahia, Brazil.

\section{Pseudotyphloscia Verhoeff, 1928 Pseudotyphloscia alba (Dollfus, 1898)}

Philoscia alba Dollfus, 1898:381, figs 29a-b, pl. 15, fig. 29; Herold, 1931:308.

Pseudotyphloscia pallida VerHOEFF, 1928:223, figs 26-30.

Pseudotyphloscia alba: GReEn et al., 1990:420, figs 2, 3; TAITI et al., 1992:790; KwON \& TAITI, 1993:14; Gregory, 2014:7, fig. 2.

Material examined. BRAZIL, Paraná: many ô and + , Antonina, near of Nunes river, road to Guaraqueçaba, $25^{\circ} 20^{\prime} 48^{\prime} \mathrm{S}, 48^{\circ} 46^{\prime} 05^{\prime \prime} \mathrm{W}$, camping area, 10.VIII.2012, P. B. Araujo \& B. L. Zimmermann col. (MZUSP 35108); $3{ }^{\lambda}, 3$ 우, same data as previous (MZUF 9644). Minas Gerais: many

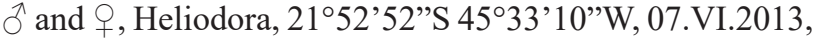
G. M. Cardoso \& I. S. Campos-Filho col. (MZUSP 35109); $3 \hat{\jmath}, 39$, same data as previous (MZUF 9643).

Remarks. Pseudotyphloscia was proposed by VerhoEFF (1928) to include P. pallida from Formosa. GreEN et al. (1990) redefined the genus based on the type material of $P$. pallida and specimens from West Java and Krakatau Islands. The authors concluded that $P$. pallida is a junior synonym of Philoscia alba Dolfuss, 1898 from Celebes described by DoLfuss (1898) and transferred the species to Pseudotyphloscia. To date, Pseudotyphloscia includes only $P$. alba. The specimens from Brazil here examined indeed correspond to the description provided by GREEN et al. (1990).

Distribution. Brazil, Southern China, glasshouses in England, Indonesia (Sulawesi, Java, Krakatau Is, Bali), Philippines, and Taiwan (KwON \& TAITI, 1993; GregorY, 2014)

\section{Balloniscidae \\ Balloniscus Budde-Lund, 1908 Balloniscus glaber Araujo \& Zardo, 1995}

Balloniscus glaber Araujo \& Zardo, 1995:785, figs 1-17; Araujo, 1999:250, fig. 18; LoPES et al., 2005:101, table 1; AlMERÃo et al., 2006:474, fig 4; MeinhardT et al., 2007:1108, figs 1, 2, tables 1, 2; Quadros \& Araujo, 2007:242, figs 1-3, tables 1, 2; 2008:59, figs 1, 2, tables 1-4; QuAdros et al., 2009:244, figs 2, 3, tables 1, 2; QuADros, 2010:573; APPEL et al., 2011:125, table 1; AlMERÃo et al., 2012:981, fig. 2, tables 1, 2; ZiMMERMANN et al., 2012:712; ZiMMERMANN et al., 2015b:3, tables 1, 2; Kenne \& Araujo, 2015:430, figs 1-7, tables 1, 2; Wood et al., 2017:4, figs 1-3, 7.

Material examined. BRAZIL, Santa Catarina: 옹 Florianópolis, Praia dos Ingleses, $27^{\circ} 26^{\prime} \mathrm{S}$, $48^{\circ} 23^{\prime}$ W, 23.X.2004, M. P. Almerão (4096). Rio Grande do Sul: many $\delta$ and + , Porto Alegre, Campus do Vale, $30^{\circ} 04$ '35”S, 51 ${ }^{\circ} 07^{\prime} 28^{\prime \prime} \mathrm{W}, 10 . X .2011$, B. L. Zimmermann col. (UFRGS 5150).

Previous Brazilian records. Rio Grande do Sul: Rio Grande and Sapucaia do Sul (Araujo \& Zardo, 1995);
Rincão dos Kroeff and Barra do Ouro (Lopes et al., 2005); PE Itapuã, Porto Alegre (Almerão et al., 2006; Quadros \& Araujo, 2007, 2008; Quadros et al., 2009); Águas Belas, Barra do Ribeiro, Cassino, Caxias do Sul, Cidreira, Colônia, Glorinha, Morro Santana, Mostardas, Palmeiras do Sul, Pelotas, Porto Alegre, São Lourenço do Sul, Tapes and Tavares, all municipalities located in Patos Lagoon region (Almerão et al., 2012; KenNe \& Araujo, 2015); Mariana Pimentel, Mostardas and Porto Alegre (Zimmermann et al., 2015b).

Remarks. In Brazil, Balloniscus is represented by two species, B. glaber and B. sellowii (Brandt, 1833). B. glaber differs from $B$. sellowii in the color aspects (three longitudinal pigmented rows, one centrally and one in each lateral margin in $B$. sellowii), telson with apical portion surpassing the distal margin of uropod protopod (not surpassing in B. sellowii), and shape of male pleopod 1 exopod with distal margin straight (rounded in B. sellowii) (ARAUJo \& ZARDO, 1995).

Distribution. This species is recorded from the states of Santa Catarina and Rio Grande do Sul, Brazil.

\section{Balloniscus sellowi (Brandt, 1833)}

Philoscia sellowii Brandt, 1833:43; Budde-Lund, 1879:2, 1885:218; Milne-Edwards, 1840:164; STUXBERG, 1875:43.

Philoscia (Balloniscus) sellowii; Budde-Lund, 1908:289, pl. XVI, fig. 3; VAN NAME, 1936:136.

Philoscia paulensis; MoreIra, 1927:194, figs 1-3; 1931:426, figs 1-8.

Balloniscus sellowii; LEMOS DE CASTRO, 1972:357; 1976:392, figs 1-13; Araujo et al., 1996:120, figs 22-27, 65; SouZa-KurY, 1998:654; Araujo, 1999:249, fig. 17; Leistikow \& WäGele, 1999:31; SCHMALFuss, 2003:51; Lopes et al., 2005:101, table 1; AlMERÃo et al., 2012:981, fig. 2, tables 1, 2; WooD et al., 2012:234, fig. 2; ZimMERMANN et al., 2015b:703, fig. 2, tables 1, 2.

Material examined. BRAZIL, Minas Gerais: many $\sigma^{\lambda}$ and 9 , Itamonte, $20^{\circ} 20^{\prime} 44^{\prime \prime}$ S, 44 48'52”W, 07.III.2014, G. M. Cardoso col. (UFRGS 5911). Paraná: $9 \hat{\jmath}$,,+1 manca,

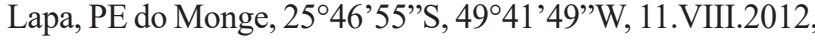
P. B. Araujo \& B. L. Zimmermann col., impacted area, near of restaurants, in woods (UFRGS 5539). Santa Catarina: $2{ }^{\lambda}, 2$, 2 , Santa Rosa de Lima, $27^{\circ} 59^{\prime} 17^{\prime \prime}$ S, $49^{\circ} 06^{\prime} 45^{\prime \prime} \mathrm{W}$, at 229 meters, 25.VI.2012, P. B. Araujo col., in pasture woods, litter with many roots (UFRGS 5578); $2 \hat{\gamma}$, + , Orleans, near of the fire department, $28^{\circ} 21^{\prime} 17^{\prime \prime} \mathrm{S}, 49^{\circ} 16^{\prime} 26^{\prime \prime} \mathrm{W}, 24$.VI.2012, P. B. Araujo \& B. L. Zimmermann col., dense vegetation cover, litter with many roots, primary forest (UFRGS 5601).

Previous Brazilian records. Brazil (BUDDE-Lund, 1908). Minas Gerais: Jacutinga (Lemos de CASTRo, 1976). Rio de Janeiro: Araruana, Barra de São João, Barra de Maricá, Cabo Frio, Rio de Janeiro and São João da Barra (Lemos DE CASTRO, 1976). Espírito Santo: Amparo (Monte Alegre and Ibiti) and Barra de Itabapoana (Lemos DE CASTRO, 1976). São Paulo: São Paulo (MoreIRA, 1927, 1931); Carapicuiba, Estrada Cabreuva-Pirapora, Itanhaem, Parque da Luz, Santo André and São Paulo (Lemos de CAStro, 1976). Paraná: Bituruna and União da Vitória (Lemos DE CASTRO 1976); Lapa (Zimmermann et al., 2015b). Santa Catarina: Anchieta, Bom 
Jardim da Serra, Bom Retiro, Campo Erê, Campos Novos, Catanduvas, Chapecó, Faxinal do Guedes, Florianópolis, Irani, Itá, Lages, Laguna, Papanduva, Ponte Serrada, Praia Grande, Santa Cecília, São Lourenço d'Oeste, São Joaquim, São Miguel d'Oeste, Sombrio, Ubirici and Xanxerê (Araujo et al., 1996); Bocaína do Sul (ZimMERMANN et al., 2015b). Rio Grande do Sul: Bento Gonçalves and Porto Alegre (LEMos DE Castro, 1976); Agudo, Alegrete, Arroio Grande, Bagé, Bom Jesus, Caçapava do Sul, Camaquã, Capão da Canoa, Capivari, Casca, Coronel Bicaco, Cidreira, Eldorado do Sul, Encruzilhada do Sul, Erechim, Estrela, Flores da Cunha, Fontoura Xavier, Garibaldi, Itaqui, Palmeira das Missões, Pelotas, Pinheiro Machado, Porto Alegre, Rio Grande (E. E. Taim), Rio Pardo, Rosário do Sul, Santiago, Santa Cruz do Sul, Santa Isabel do Sul, Santa Maria, Santana do Livramento, Santo Ângelo, Sarandi, São Gabriel, São Lourenço do Sul, São Luiz Gonzaga, São Vicente do Sul, Tapes, Taquara, Três Passos, Tramandaí, Triunfo, Veranópolis and Viamão (Araujo et al., 1996); Rincão dos Kroeff and Barra do Ouro (Lopes et al., 2005); Águas Belas, Barra do Ribeiro, Cassino, Caxias do Sul, Cidreira, Colônia, Glorinha, Morro Santana, Mostardas, Palmeiras do Sul, Pelotas, Porto Alegre, São Lourenço do Sul, Tapes and Tavares, all municipalities located in Patos Lagoon region (ALMERÃo et al., 2012); Porto Alegre (Wood et al., 2012); Arroio do Sal, Barra do Ribeiro, Mostardas, Pelotas, Porto Alegre and Vacaria (ZimMERMANN et al., 2015b).

Distribution. This species is widely distributed in southern Brazil, Uruguay and Argentina.

Scleropactidae

Amazoniscus Lemos de Castro, 1967

Amazoniscus zimmeri Campos-Filho, Montesanto \& Araujo sp. nov.

(Figs 28-50)

http://zoobank.org/urn:lsid:zoobank.org:act:598088777010-42D0-8774-617AF5E05415

Type material. BRAZIL, Pará: Holotype đ̂̃, Belém, MPEG, 19.XI.2012, P. B. Araujo col. (MZUSP 35110). Paratypes: $\widehat{0}, 2$, , same data as holotype (MZUSP 35111).

Description. Maximum body length: ㅈ $5.5 \mathrm{~mm}$, 우 $5 \mathrm{~mm}$. Color brown; cephalon with irregular unpigmented spots; antenna, pereon, pleon and uropods strongly pigmented; pereon with some unpigmented spots on paramedian region, pleonites 1-3 with two small unpigmented spots, and telson with 3 small unpigmented spots. Body convex, exoantennal conglobation (Fig. 28). Dorsum smooth, with some scattered triangular scale-setae (Fig. 29); one line of noduli laterales per side, more or less at same distance from lateral margins and close to posterior margins of pereonites (Figs 28, 32); no visible gland pores. Cephalon (Figs 30, 31) with frontal shield slightly bent backwards over vertex, frontal margin broadly rounded; eyes of 12-13 ommatidia. Pereonite 1
(Fig. 32) with no schisma or ventral lobe; pereonites 1-4 with posterior margin straight, 5-7 gradually more concave; pereonites 1-7 with posterior margin slightly sinuous at sides (Fig. 28). Pleon (Figs 33, 34) with outline continuous with that of pereonite 7, epimera 3-5 well developed, directed backwards with acute apices. Telson (Fig. 33) triangular, slight concave sides, rounded apex. Antennula (Fig. 35) of three articles, proximal article longest, distal article with three rows of two aesthetascs. Antenna (Fig. 36) reaching posterior margin of second pereonite when extended backwards, fifth article of peduncle longer than flagellum, flagellum of two articles subequal in length, distal article with two rows of two aesthetascs each, apical organ as long as second article of flagellum with simple and short free sensilla. Mandibles (Figs 37, 38) with molar penicil dichotomized, consisting of about 10 branches, left mandible with $2+1$ penicils, right with 1+1 penicils. Maxillula (Fig. 39) inner branch bearing two subequal penicils, distal margin rounded; outer branch with $4+6$ teeth (four cleft) plus accessory tooth and slender seta. Maxilla (Fig. 40) outer lobe about twice as broad as medial lobe, distal margin rounded; inner lobe rounded, covered with thick setae. Maxilliped (Fig. 41) basis rectangular bearing sparse scale-setae, distal margin with fringe of thin setae; endite rectangular, distal margin almost straight with one small seta on outer portion, and short penicil; palp with three tufts of setae, proximal article with one long inner seta. Pereopods with short inner claw, ungual seta long and simple, long dactylar seta reaching tip of outer claw (Fig. 43). Pleopods 1 and 2 with respiratory areas. Uropod (Fig. 42) with insertion of endopod and exopod at different levels, protopod flattened and enlarged, endopod twice as long as exopod.

Male: Pereopod 1 (Fig. 43) ischium, merus and carpus with sternal margin covered with short scales. Pereopod 7 (Fig. 44) ischium elongated with almost straight sternal margin; carpus twice as long as merus. Genital papilla as in Fig. 45. Pleopod 1 (Fig. 46) exopod triangular, with convex outer margin; endopod more than twice as long as exopod bearing small setae along inner margin, distal portion tapering. Pleopod 2 (Fig. 47) exopod triangular, outer margin sinuous bearing two small setae; endopod distinctly longer than exopod. Pleopod 3 exopod (Fig. 48) rhomboid, outer margin slightly concave bearing two small setae, inner and outer margins fringed with thin setae. Pleopod 4 exopod (Fig. 49) triangular, outer margin almost straight with three small setae, inner and outer margins fringed with thin setae. Pleopod 5 exopod (Fig. 50) triangular, distal part narrower and acute, outer margin sinuous with one small seta, inner and outer margins fringed with thin setae.

Etymology. The new species is named after Dr. Martin Zimmer for his contribution to the knowledge on the biology of Oniscidea.

Remarks. Amazoniscus Lemos de Castro, 1967 includes three Brazilian species from Amazonian rainforest and Atlantic forest domains: A. arlei Lemos de Castro, 1967 from the states of Amapá, Pará and Tocantins (LEMOS DE 


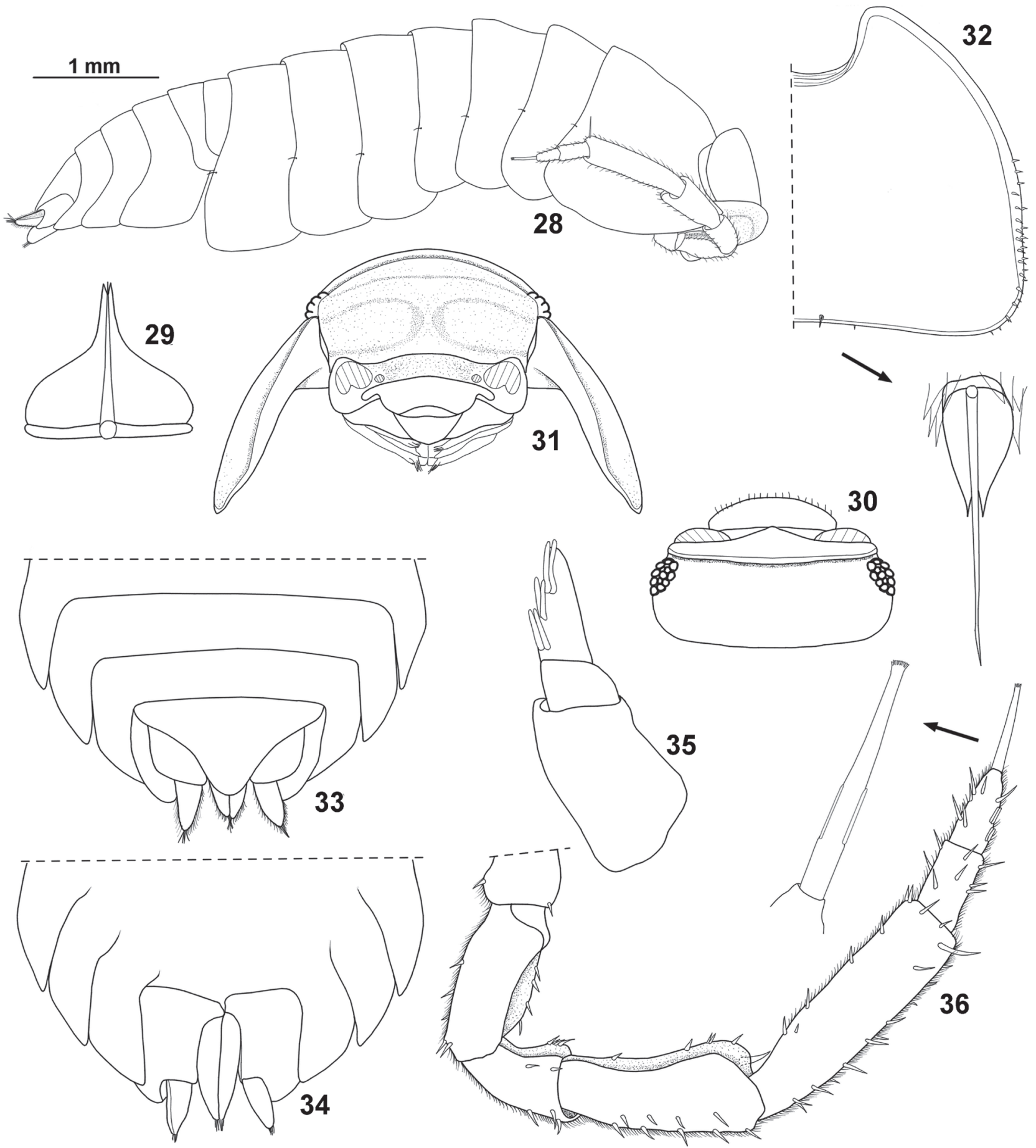

Figs 28-36. Amazoniscus zimmeri Campos-Filho, Montesanto \& Araujo sp. nov., §̋ paratype: 28, adult specimen, lateral view; 29, dorsal scale-seta; 30, cephalon, dorsal view; 31, cephalon, frontal view; 32, pereonite 1 and nodulus lateralis; 33, pleonites 3-5, telson and uropods, dorsal view; 34, pleonites 3-5 and uropods, ventral view; 35, antennula; 36, antenna.

CASTRo, 1967); and two troglobitic species from the state of Pará, A. eleonoare Souza, Bezerra \& Araújo, 2006 and A. leistikowi Campos-Filho, Araujo \& Taiti, 2014.

Amazoniscus zimmeri sp. nov. differs from all the other species in the genus by the shape of the male pleopod
1 exopod, i. e. with convex instead of concave outer margin as in $A$. arlei, longer than wide instead of wider than long as in A. eleonorae and A. leistikowi, it also differs from $A$. leistikowi in having the distal part of the male pleopod 1 endopod almost straight instead of distinctly bent outwards. 


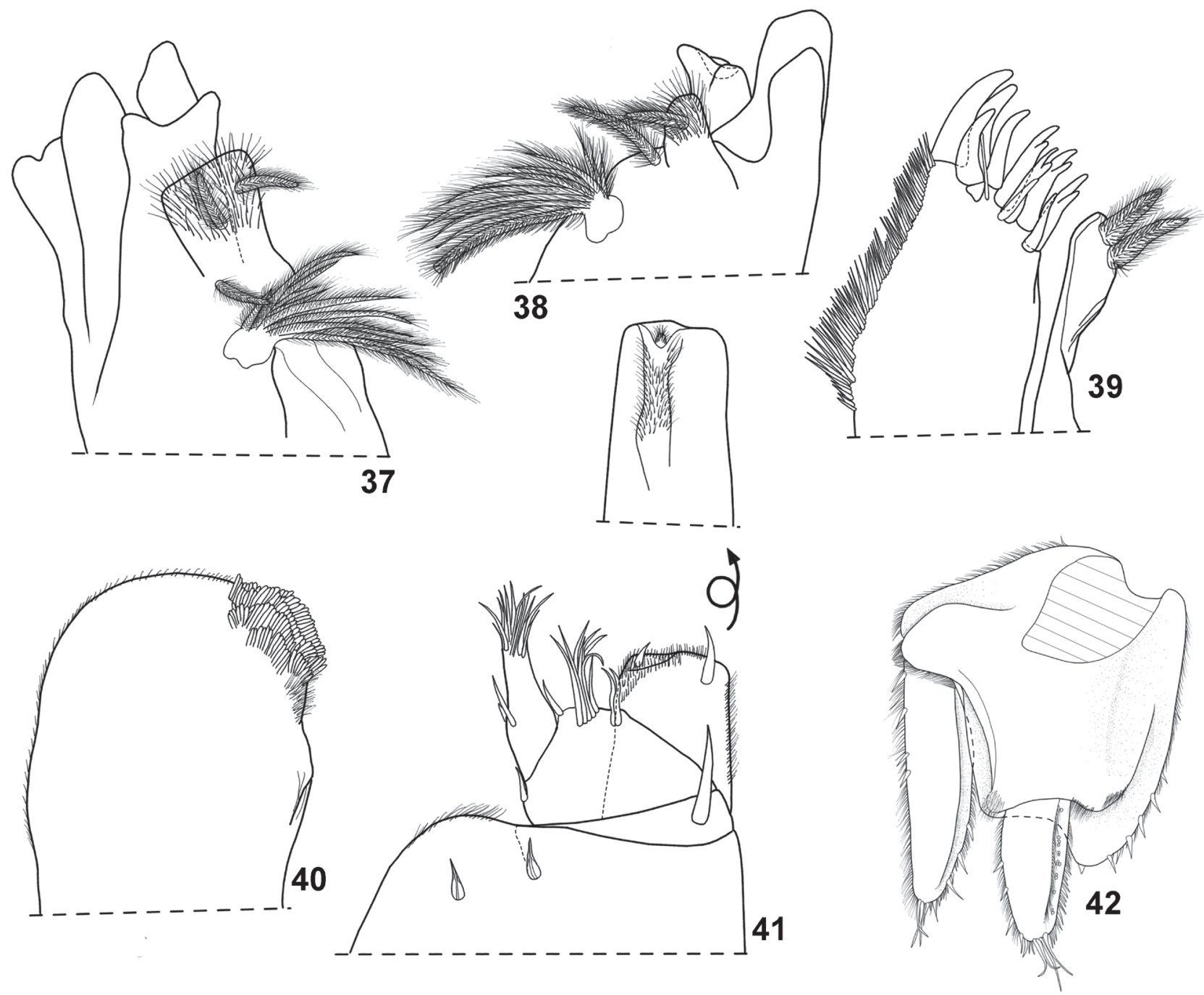

Figs 37-42. Amazoniscus zimmeri Campos-Filho, Montesanto \& Araujo sp. nov., + paratype: 37, left mandible; 38, right mandible; 39, maxillula; 40, maxilla; 41, maxilliped; 42, uropod.

\section{Amazoniscus schmidti Campos-Filho, Montesanto \& Taiti sp. nov.}

(Figs 51-73)

http://zoobank.org/urn:1sid:zoobank.org:act:4BCD8697F127-4546-8084-8E9870AB2EE2

Amazoniscus arlei; ScHмIDT, 2007: 64, figs 192-195 (partim: specimens from Leopoldina, state of Minas Gerais).

Type material. BRAZIL, Minas Gerais: Holotype $\widehat{\partial}$, Belo Horizonte, undated, H. A. Pinto col. (MZUSP 35112). Paratypes: $3+$, same data as holotype (MZUSP 35113 ).

Description. Maximum body length: $\overbrace{}^{\lambda} 8.5 \mathrm{~mm}$, +9.5 $\mathrm{mm}$. Color brown; cephalon with irregular unpigmented spots; antenna unpigmented; pereon more pigmented on median portion and epimera, unpigmented spots on paramedian region; pleon and uropods darker, pleonites 1-3 and telson with two unpigmented spots. Body convex, exoantennal conglobation (Fig. 51). Dorsum smooth with some scattered triangular scale-setae (Fig. 52); one line of noduli laterales per side, more or less at same distance from lateral margins and close to posterior margins of pereonites (Fig. 51); no visible gland pores. Cephalon (Figs 53-55) with frontal shield bent backwards over vertex, frontal margin broadly rounded; eyes of 13-15 ommatidia. Pereonite 1 without schisma or ventral lobes; pereonites 1-4 with posterior margin straight, 5-7 gradually more concave (Figs 51, 55). Pleon (Figs 56, 57) continuous with pereon, epimera $3-5$ well developed, directed backwards with acute apex. Telson (Fig. 56) triangular, short, twice as broad as long, with slightly concave sides, rounded apex. Antennula (Fig. 58) of three articles, third article about three times as long as second, bearing five rows of two aesthetascs each and apically pointed. Antenna (Fig. 59) reaching posterior margin of second pereonite when extended back, fifth article of peduncle twice as long as flagellum, flagellum with two articles subequal in length, distal article with two rows of two aesthetascs each, apical organ as long as second article of flagellum with simple and short free sensilla. Mandible (Figs 60,61) with molar penicil 


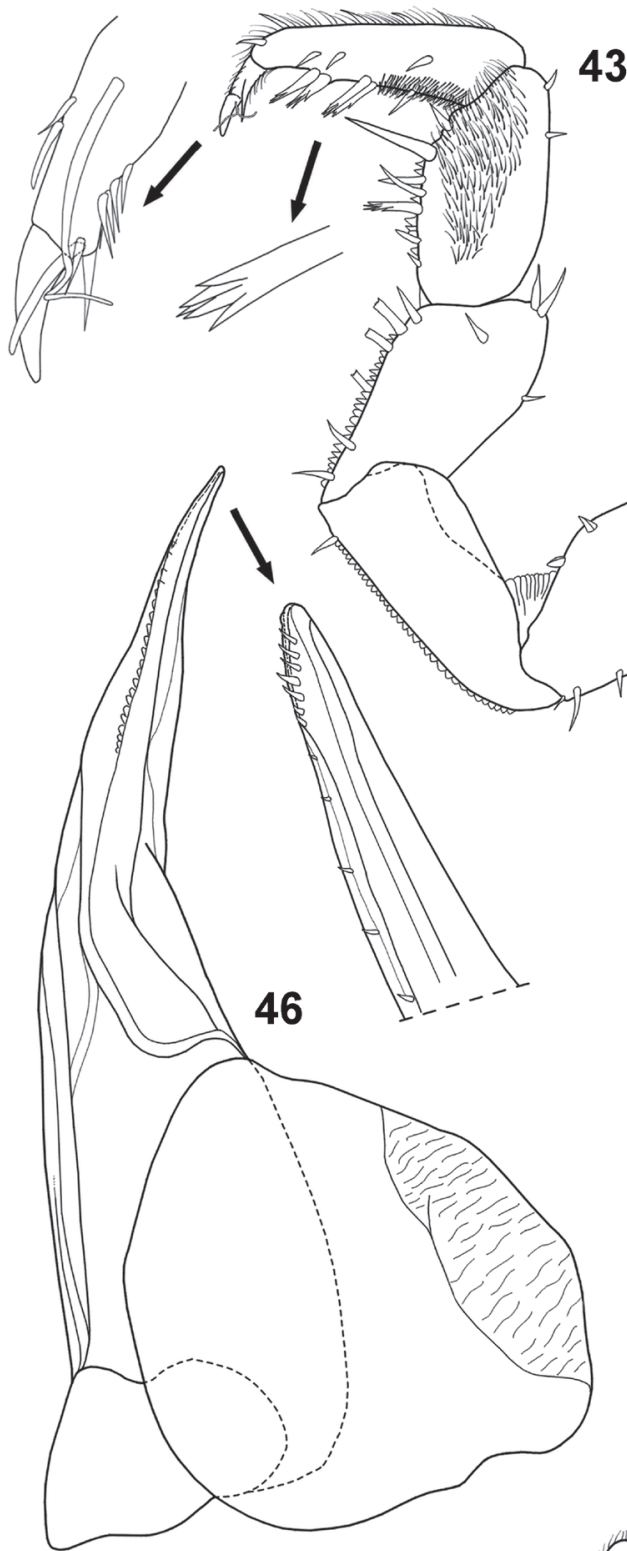

43
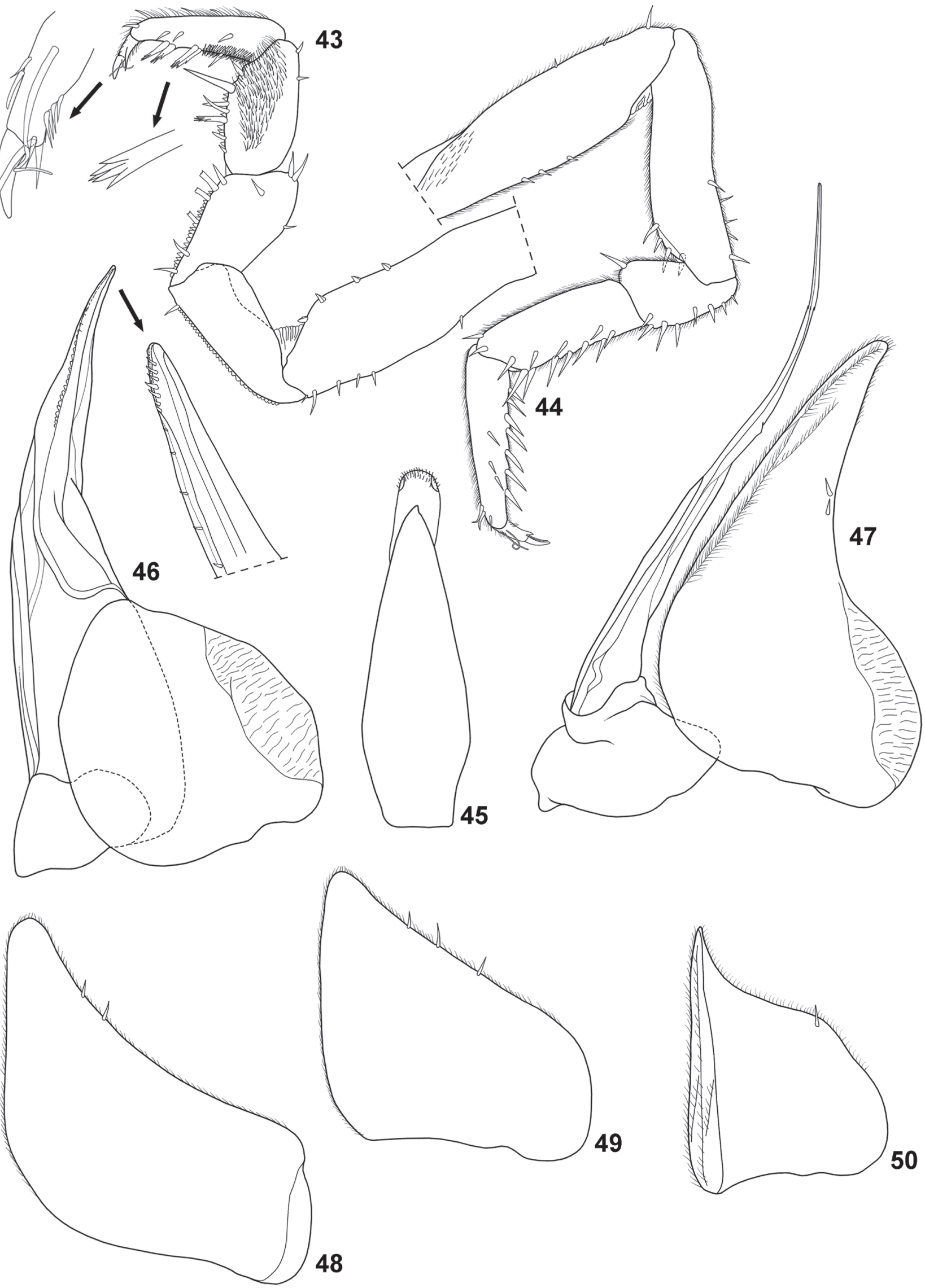

49

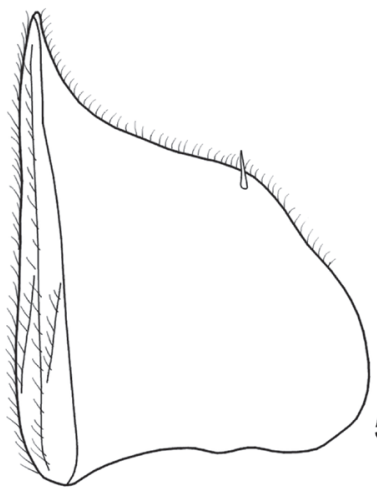

50

Figs 43-50. Amazoniscus zimmeri Campos-Filho, Montesanto \& Araujo sp. nov., ô paratype: 43, pereopod 1; 44, pereopod 7; 45, genital papilla; 46, pleopod 1; 47, pleopod 2; 48, pleopod 3 exopod; 49, pleopod 4 exopod; 50, pleopod 5 exopod. 


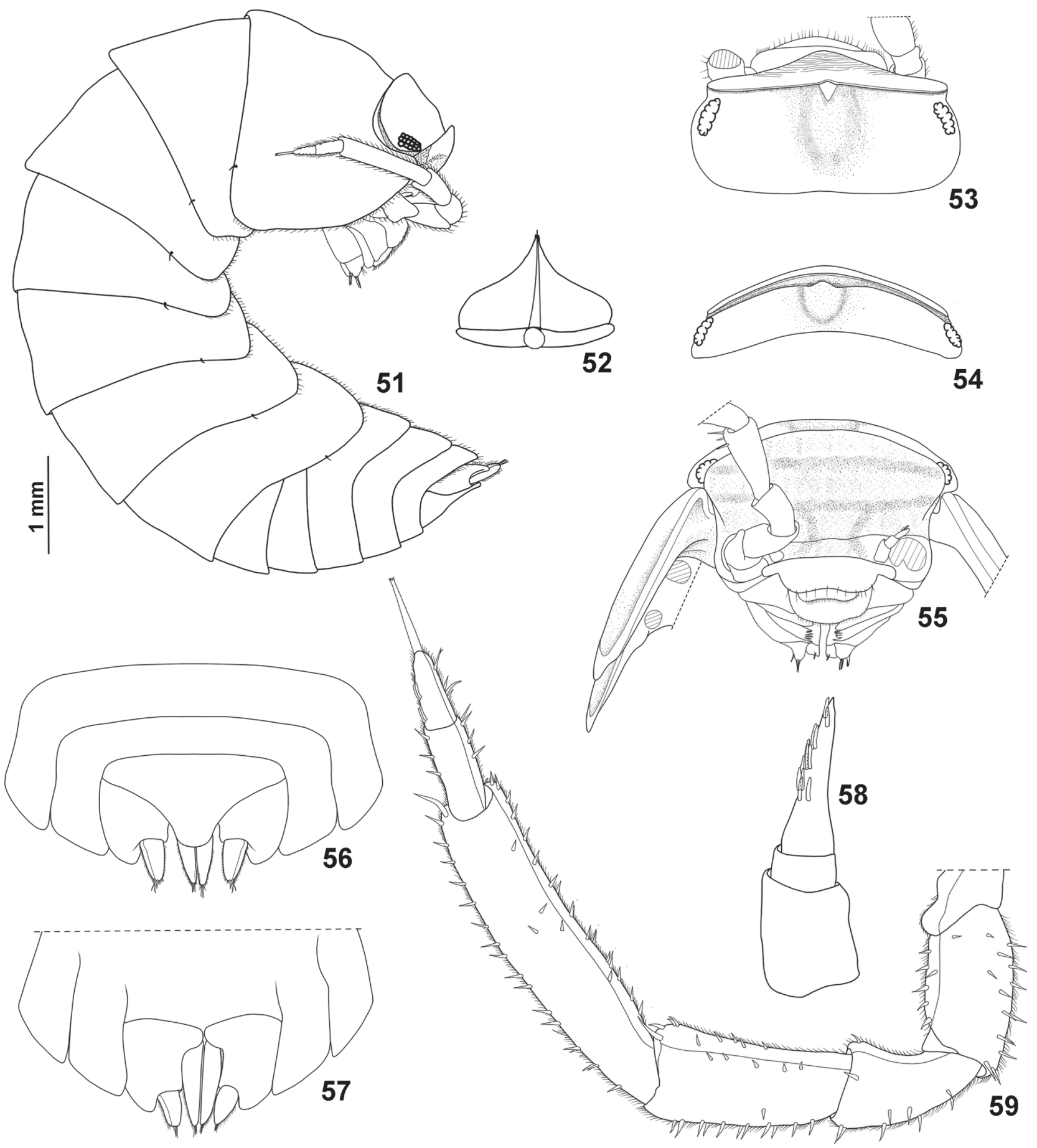

Figs 51-59. Amazoniscus schmidti Campos-Filho, Montesanto \& Taiti sp. nov., ô holotype: 51, adult specimen, lateral view; 52, dorsal scale-seta; cephalon: 53, dorsal view; 54, caudal view; 55, cephalon and pereonites 1 and 2, frontal view; 56, pleonites 4 and 5, telson and uropods, dorsal view; 57, pleonites 4 and 5, and uropods, ventral view; 58 antennula; 59, antenna.

dichotomized, consisting of about 10 branches, left mandible with $2+1$ penicils, right with $1+1$ penicils. Maxillula (Fig. 62) with inner branch bearing two subequal penicils, distal margin rounded with very short posterior point; outer branch with $4+6$ (four cleft) teeth plus accessory tooth and slender seta. Maxilla (Fig. 63) outer lobe about twice as broad as medial lobe, distal margin rounded, covered with thin setae; inner lobe rounded, covered with thick setae. Maxilliped (Fig. 64) with basis rectangular bearing sparse scale-setae, distal margin with fringe of thin setae; endite rectangular, distal margin slightly rounded with one triangular seta and short penicil; palp with three tufts of setae, proximal article 
with one inner seta. Pereopods with short inner claw, ungual seta long and simple, long dactylar seta reaching tip of outer claw. Pleopods 1 and 2 with respiratory areas. Uropod (Fig. 65 ) with insertion of endopod and exopod at different levels, protopod flattened and enlarged, endopod twice as long as exopod.

Male: cephalon (Figs 53, 54) with rounded dorsal depression on vertex bearing one triangular structure near frontal shield. Pereopod 1 (Fig. 66) merus and carpus with sternal margin covered with short scales and sparse strong setae. Pereopod 7 (Fig. 67) ischium elongated, sternal margin concave; merus with medial ridge bearing setae; carpus twice as long as merus. Genital papilla as in Fig. 68. Pleopod 1 (Fig. 69) exopod with very sinuous outer margin, distal part triangular; endopod longer than exopod, bearing small setae along median margin, distal portion slightly depressed subapically bearing line of small setae. Pleopod 2 (Fig. 70) exopod outer margin strongly sinuous bearing one small seta; endopod as long as exopod. Pleopod 3 and 4 exopods (Figs 71, 72) subrectangular bearing three small setae each, inner and outer margins fringed with thin setae. Pleopod 5 exopod (Fig. 73) triangular, distal part narrower and acute, outer margin sinuous with one small seta, inner and outer margins fringed with thin setae.

Etymology. The new species is named after Dr. Christian Schmidt, for his valuable contribution on the taxonomy of the family Scleropactidae.

Remarks. Schmidt (2007), in his study of the Neotropical Scleropactidae, redefined the genus Amazoniscus and redescribed $A$. arlei based on the type material from the north of Brazil in the states of Amapá and Pará. The author extended the records of this species to the states of Minas Gerais and Rio de Janeiro (southeastern Brazil); the material is deposited in the collection of MNRJ. Based on the illustrations provided by the author, it is possible to observe clear differences between north- and southeastern specimens. The northern specimens show the male pereopod 7 ischium triangular shaped, slightly concave on sternal margin (vs. rounded and strongly concave), the dactylar organ with setose apex (vs. simple), the male pleopod 1 exopod with the distal portion acute (vs. triangular), the male pleopod 1 endopod with distal inner portion bent inwards (vs. depressed and slightly bent outwards). Based on the characters of the male pereopods 1, 2 and 7 and pleopods 1 and 2, we assume
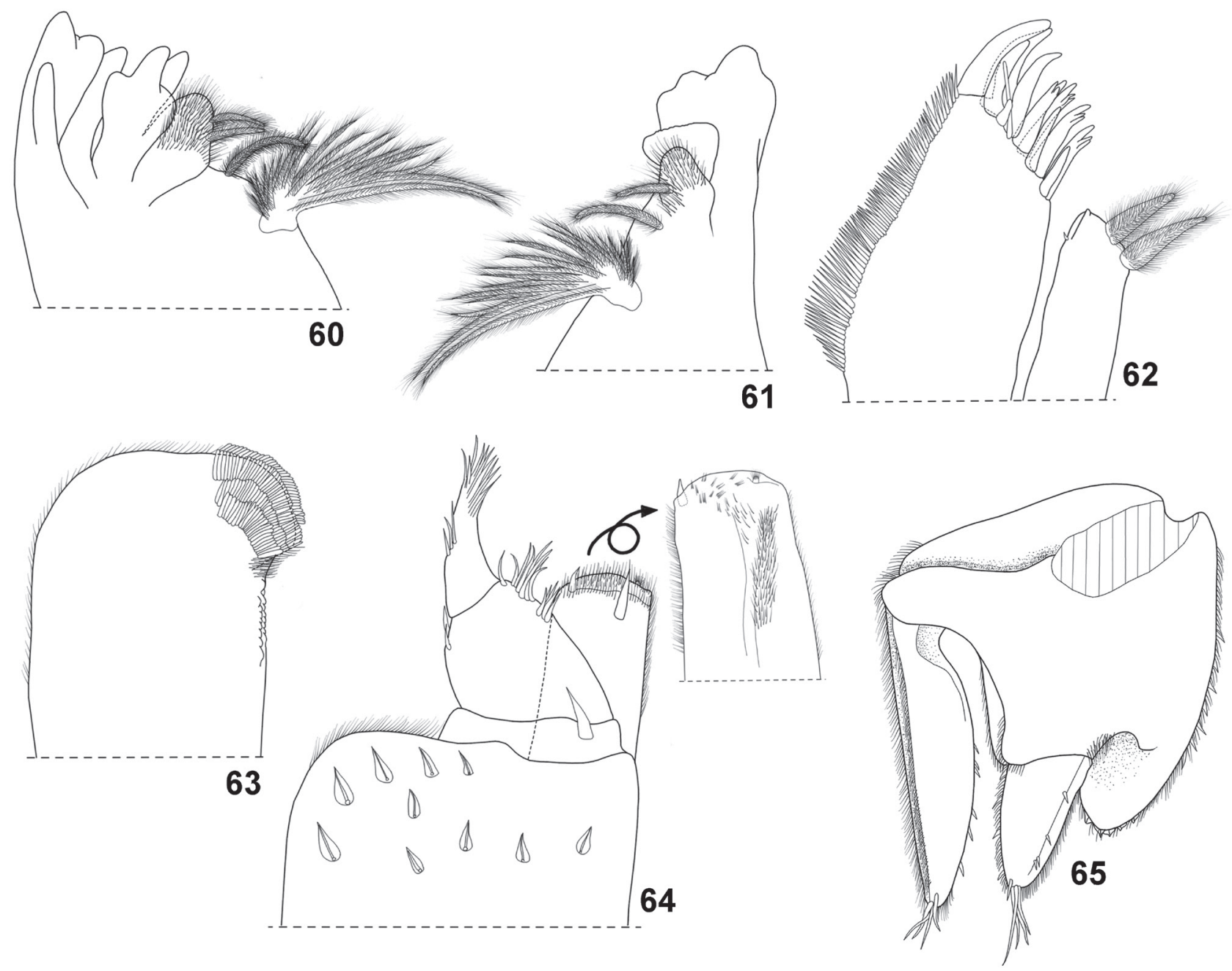

Figs 60-65. Amazoniscus schmidti Campos-Filho, Montesanto \& Taiti sp. nov.,, paratype: 60, left mandible; 61, right mandible; 62, maxillula; 63, maxilla; 64 , maxilliped; 65 , uropod. 


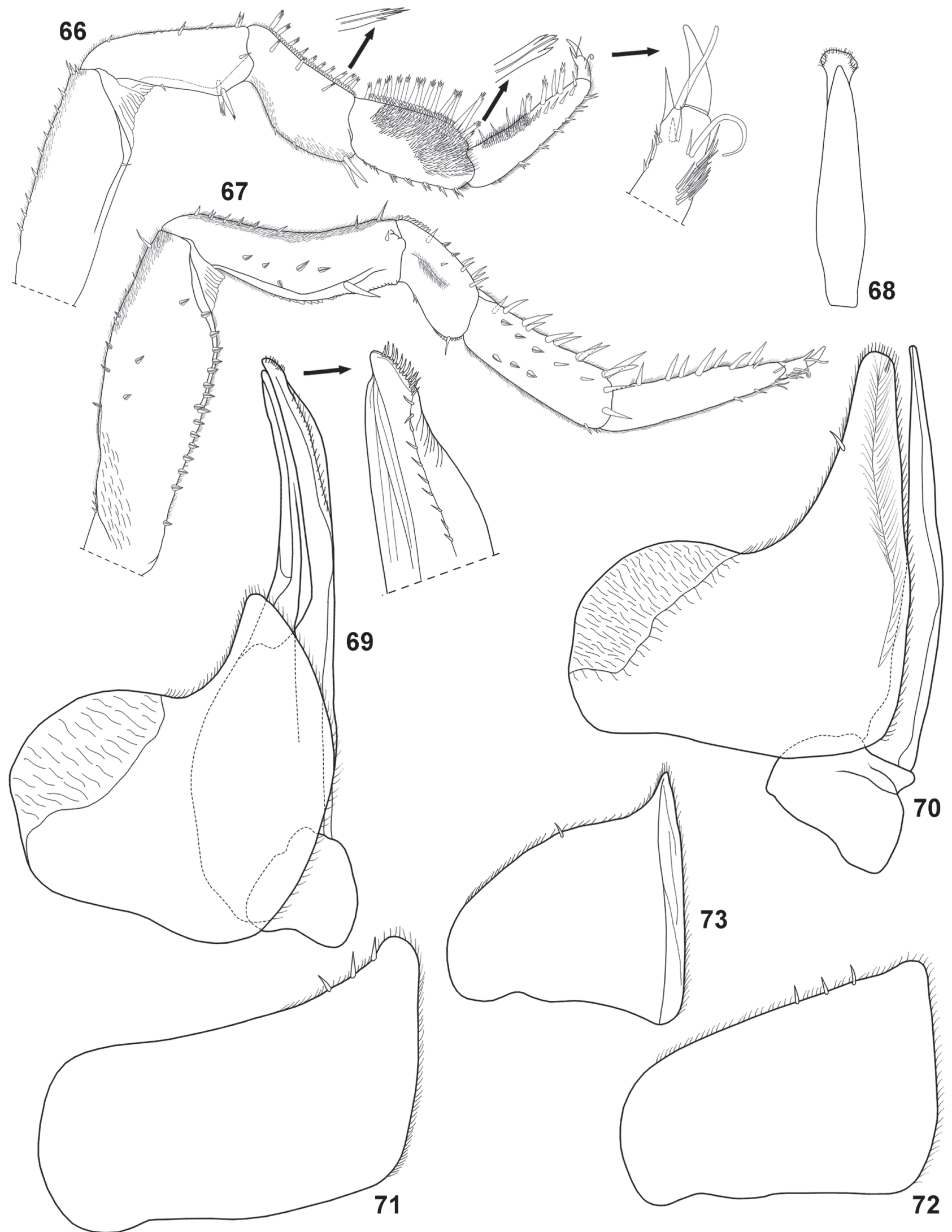

Figs 66-73. Amazoniscus schmidti Campos-Filho, Montesanto \& Taiti sp. nov., §̂ holotype: 66, pereopod 1; 67 pereopod 7; 68, genital papilla; 69, pleopod 1; 70, pleopod 2; 71, pleopod 3 exopod; 72, pleopod 4 exopod; 73, pleopod 5 exopod. 
that the species illustrated by the author from the state of Minas Gerais, corresponds to the new species described here. The material from the state of Rio de Janeiro needs to be re-examined to confirm if it belongs to Amazoniscus schmidti sp. nov..

Amazoniscus schmidti sp. nov. is similar to A. arlei in the falciform shape of the male pleopod 1 exopod, but it is easily distinguished by the male cephalon with dorsal rounded depression and triangular lobe, male pereopod 1 merus and carpus with slightly sparse setae on sternal margin, carpus 1 with large antennal grooming brush, pereopod 7 ischium long, dorsal margin rounded and strongly concave on sternal margin, dactylar organ simple without hairy appearance, the male pleopod 1 exopod with triangular distal portion, and the male pleopod 1 endopod with distal inner depression and directed outwards.

Circoniscus Pearse, 1917 Circoniscus bezzii Arcangeli, 1931

Circoniscus bezzii ArCangeli, 1931:115, plate II; Van Name, 1936:311, fig. 184; Vilela et al., 1971:185; SouZa \& Lemos de CASTro, 1991:50, figs 23-44; Schultz, 1995:417, fig. 12J-M; SouZa-KurY, 1998:666; Leistikow \& WÄGele, 1999:38; Schmalfuss, 2003:81; SChMidT, 2007:72, figs 224-229; CAMPOS-FiLHO et al., 2014:396, 0.

Material examined. BRAZIL, Minas Gerais: 59 , 1 juvenile, Serra da Canastra, Casca D'Anta, 20¹8'47'S, $46^{\circ} 31$ ' $47^{\prime \prime} \mathrm{W}$, at 861 meters, 13.VI.2013, riparian forest (UFRGS 5720); ㅇ, São João Batista da Glória, 20³6'12”S, 46²5'16"W, 13.VI.2013, I. S. Campos-Filho \& G. M. Cardoso col., Cerrado biome (UFRGS 5718); q, Carmo do Rio Claro, 2058'05"S, 46¹8'43”W, 12.VI.2013, I. S. Campos-Filho \& G. M. Cardoso col. (UFRGS 5715); 2 , Carmo do Rio Claro, 11.VI.2013, I. S. Campos-Filho \& G. M. Cardoso col. (UFRGS 5712); ㅇ, Varginha, 21³3’21'S, 4526'12"W, 15.VI.2013, I. S. Campos-Filho \& G. M. Cardoso col. (UFRGS 5725).

Previous Brazilian records. Minas Gerais: Alfenas (Souza \& Lemos de Castro, 1991); Presidente Olegário (CAmpos-Filho et al., 2014). Espírito Santo: Linhares and Santa Tereza (Souza \& Lemos de CAStro, 1991). Mato Grosso: Carandasinho (ArCANGeli, 1931; Souza \& Lemos de CAstro, 1991). São Paulo: Amparo, Capivari, Descalvado, Mogi-Guassú, Nova Europa, Pirassununga, São Carlos, Tabatinga and Urucai (Souza \& Lemos de CAStro, 1991).

Distribution. This species is recorded from Brazil (states of Minas Gerais, Espírito Santo, Mato Grosso and São Paulo) and Paraguay.

\section{Pudeoniscidae \\ Pudeoniscus Vandel, 1963 \\ Pudeoniscus birabeni Vandel, 1963}

Pudeoniscus birabeni Vandel, 1963:91, figs 16-19; Lemos de Castro, 1973:3; SouZa-KurY, 1998:665; LeistiKow \& WÄGELE, 1999:43; Schmalfuss, 2003:226; Schmidt, 2003:79, figs 100-103; LisBOA et al., 2013:395.
Material examined. Bahia: đ̃, Salvador, Baía de Aratu, IX.2006, J. T. Lisboa col. (UFRGS 4231); ㅇ, Ilhéus, UESC, 25.VIII.2013, J. T. Lisboa col. (MZUF 9649).

Previous Brazilian records. Bahia: Ilhéus (LisBoA et al., 2013). Rio de Janeiro: Pico de Tijuca, Rio de Janeiro (VAndel, 1963; Schmidt, 2003); Angra dos Reis (Ilha Grande), Mangaratiba (Ribeira, Rubião, Muriqui) and Rio de Janeiro (Açude da Solidão, Floresta da Tijuca, Furnas da Tijuca, Pedra do Conde, Represa dos Ciganos) (Lemos DE CAStro, 1973). São Paulo: Estrada Velha Santos-São Paulo, Piassaguera and Santos (Lemos DE CASTRo, 1973).

Distribution. This species is recorded from the states of Bahia, Rio de Janeiro and São Paulo.

\section{Platyarthridae}

Remarks. At present the family Platyarthridae includes more than 110 species in nine genera, mainly distributed in tropical areas. The family is most probably paraphyletic (SCHMIDT, 2003). Recently, the new family Paraplatyarthridae Javidkar \& King, 2015 (Crinocheta) was erected to accommodate the new genus and the new species Paraplatyarthrus subterraneus Javidkar \& King, 2015 from Laverton Downs, Windarra calcrete, Eastern Murchison region, Western Australia (JAVIDKAR et al., 2015), and an unnamed and undescribed genus from southern Brazil. These two species are morphologically very similar to the genus Trichorhina, presently included in the Platyarthridae. Paraplatyarthridae is defined by dorsal surface with fan-like scale setae, antenna ventrally with leaf-like setae and furrow with hair-like capillary setae, part of water conduction system (WCS), flagellum of two articles, cephalon with postfrons and profons fused, maxillula outer endite with $4+4 / 5$ teeth (one shorter). The family was erected with an integrative taxonomy approach, using molecular and morphological data, and it was recovered as monophyletic. At the moment, the morphological characters proposed by the authors to define the family do not show any synapomorphy, which allows its recognition. This also occurrs in phylogenetical analyses of other genera of Oniscidea (see ScHMIDT 2002, 2003). The dorsal fan-shaped scale-setae are shared with other genera and families of Crinocheta, for example, some members of Philosciidae (Caraiboscia Vandel, 1968, Metaprosekia Leistikow, 2000) (see LeISTIKow, 2000; CAMPOS-FILHo et al., 2014), members of Dubioniscidae Schultz, 1995 (see CARDoso et al., 2016), members of Spelaeoniscidae Vandel, 1948 (see ScHmidT, 2003), and the genus Chileoniscus Taiti, Ferrara \& Schmalfuss, 1986 (incertae sedis) (see ScHMIDT, 2007). This structure seems to be related with an endogean way of life and it has an anti-adhesive function (SCHMALFUSS, 1978). Most probably this structure evolved by convergence or parallelism since it occurs in different families of Crinocheta (SCHMIDT, 2002). The furrow bearing setae on the antenna belongs to the WCS (HoESE, 1981; SCHMALFUSS, 1998), and it is present in many different Crinocheta families (see SCHMIDT, 2003). The fused postfrons and profons on the cephalon, 
together with the $4+4 / 5$ teeth on the maxillula outer endite are present in many genera of Crinocheta (LEISTIKOW, 2001; SCHMIDT, 2003, 2007). Recently, JAVIDKAR et al. (2017) added new diagnostic characters to the family, such as dorsal surface smooth, one line of noduli laterales per side on pereonites 1-6 and pereonite 7 with two noduli laterales per side. The presence of two noduli laterales per side on pereonite 7 is also observed in Trichorhina tomentosa (Budde-Lund, 1893), type species of the genus (see SCHMIDT, 2003), as well as in members of Philosciidae, i. e. Barnardoscia Taiti \& Ferrara, 1982, Anchiphiloscia Taiti \& Ferrara, 1980, and Benthanops Barnard, 1932, Hawaiioscia Schultz, 1973 (see TAITI \& FERRARA, 1987). In conclusion, if the family Paraplatyartridae migth be well characterized molecularly, it does not seem to be so from a morphological point of view.

Trichorhina Budde-Lund, 1908

\section{Trichorhina argentina Vandel, 1963}

Trichorhina argentina VANDEL, 1963:73, fig. 6; Araujo \& BucKuP, 1996a:800, figs 1-15, 41; LeISTIKOW \& WÄGELE, 1999:28; SCHMALFUSS, 2003:275; Lopes et al., 2005:101, table 1; SouZa et al., 2011:241; CAmpos-Filho et al., 2014:405; Zimmermann et al., 2015b:3, table 1.

Material examined. BRAZIL, Santa Catarina: $3 \hat{\jmath}, q$, Rancho Queimado, Bauer Hotel, 2740'57'S, 4902'41' W, 25.VI.2012, P. B. Araujo \& B. L. Zimmermann col., impacted area, in woods (UFRGS 5571).

Previous Brazilian records. Santa Catarina: Joaçaba and Sombrio (Araujo \& Buckup, 1996a). Rio Grande do Sul: Caçapava do Sul, Camaquã, Camobi (UFSM), Eldorado do Sul and Rio Grande (E. E. Taim) (Araujo \& BuckuP, 1996a); Rincão dos Kroeff and Barra do Ouro (Lopes et al., 2005); Porto Alegre (Zimmermann et al., 2015b).

Distribution. This species is recorded from southern Brazil (states of Santa Catarina and Rio Grande do Sul) and eastern Argentina.

\section{Trichorhina bicolor Araujo \& Buckup, 1996}

Trichorhina bicolor ARAujo \& BUCKUP, 1996a:806, figs 26-41; LeISTIKow \& WäGELE, 1999:28; Schmalfuss, 2003:275; SouZA et al., 2011:241.

Material examined. BRAZIL, Paraná: + , Matinhos, PARNAT Saint-Hilaire Lang, PR-508 road, 25³8'39'S, 48 36'04'W, 10.VIII.2012, P. B. Araujo \& B. L. Zimmermann col., in leaf litter (UFRGS 5557); $2 \hat{\jmath}, 4$ ㅇ, Antonina, near of Nunes river, road from Guaraqueçaba, $25^{\circ} 20^{\prime} 48^{\prime \prime} \mathrm{S}$, 48 46'05'W, 10.VIII.2012, P. B. Araujo \& B. L. Zimmermann col., camping area (UFRGS 5515). Santa Catarina: $\hat{\jmath}$, 3 ㅇ, Corupá, RPPN Rota das Cachoeiras, 2624'08'S, 49²0’40”W, 28.VI.2012, P. B. Araujo \& B. L. Zimmermann col. (UFRGS 5595); đ̃, Corupá, near of the ecological hotel, $26^{\circ} 25^{\prime} 23^{\prime}$ 'S, 49¹4'46”'W, 27.VI.2012, P. B. Araujo \& B. L. Zimmermann col., under Palm tree leaves (UFRGS 5590); ․ Rio Fortuna, 2806'09'S, 4907'35'W, 25.VI.2012, alt. 229 meters, P. B. Araujo \& B. L. Zimmermann col., in woods on pasture area, many roots, impacted area (UFRGS 5581); $5{ }^{\lambda}, 6$ ㅇ, Orleans, behind Real Nob Hotel, 28²1'17'S, 49¹6'29'W, 24.VI.2012, P. B. Araujo \& B. L. Zimmermann col., humid forest, in bromeliads leaves (UFRGS 5565).

Previous Brazilian records. Santa Catarina: Pouso Redondo, São Bonifácio and Tubarão (Araujo \& BuCKuP, 1996a).

Distribution. This species is recorded from Brazil (states of Paraná and Santa Catarina).

\section{Trichorhina kaingangi Campos-Filho, 2015}

Trichorhina kaingangi CAMPOS-FILHO et al., 2015b:114, figs 2-4.

Material examined. BRAZIL, Paraná: $\widehat{\jmath}, 3$, , São Mateus do Sul, near of road, 2557'30'S, 50³1'10"W, 11.VIII.2012, P. B. Araujo \& B. L. Zimmermann col., in woods, impacted area (MZUF 9659).

Previous Brazilian records. Paraná: Ermida Paiol do Alto cave, Adrianópolis and Água Boa cave, Almirante Tramandaré (CAmpos-Filho et al., 2015b).

Distribution. This species is recorded only from the state of Paraná, Brazil.

\section{Trichorhina tomentosa (Budde-Lund, 1893)}

Alloniscus tomentosus BudDE-LUND, 1893:126.

Trichorhina tomentosa; Lemos De CASTro, 1967:315, 1971:10, fig. 6; LENKO, 1971:5; SouZA-KurY, 1997:181, figs 1, 4-7; 1998:663; ArAuJO \& Buckup, 1996a:803, figs 16-25, 41; Leistikow \& WäGELE, 1999:30; Souza et al., 2011:241.

Material examined. BRAZIL, Bahia: 5 ㅇ, Itajú-Itapé, $15^{\circ} 01^{\prime} 58^{\prime}$ 'S, 39³6'15”W, 17.IX.2013, I. S. Campos-Filho \& J. T. Lisboa col. (UFRGS 5815); 8ㅇ, Una, ReBio Una, $15^{\circ} 10^{\prime} 08^{\prime}$ 'S, 3900'03”'W, 19.IX.2013, I. S. Campos-Filho \& J. T. Lisboa col. (UFRGS 5814). Minas Gerais: 우, Itamonte, 20²0’44”S, 4448'52”'W, 07.III.2014, G. M. Cardoso col. (UFRGS 5910). Paraná: 4엉, Antonina, near of Nunes river, road from Guaraqueçaba, $25^{\circ} 20^{\prime} 48^{\prime}$ 'S, $48^{\circ} 46^{\prime} 06^{\prime} \mathrm{W}$, 10.VIII.2012, P. B. Araujo \& B. L. Zimmermann col., camping area (UFRGS 5514); 4ㅇ, São Mateus do Sul, 2557'30'S, 50³1'10'W, 11.VIII.2012, P. B. Araujo \& B. L. Zimmermann col, open vegetation cover, in woods (UFRGS 5510). Santa Catarina: 4 ,

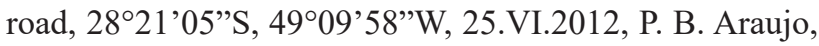
B. L. Zimmermann \& A. Ferrari col., in abandoned house, between tiles and bricks (UFRGS 5606). Rio Grande do Sul:

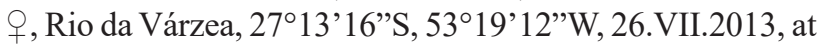
538 meters, G. M. Cardoso col., abandoned house (UFRGS 5734).

Previous Brazilian records. Pará: Belém (Lemos de Castro, 1967), Park of MPEG, Belém (Souza-Kury, 1998). Espírito Santo, Minas Gerais, Pará, Rio de Janeiro and São Paulo (Lemos de CASTRo, 1971). São Paulo: Barueri and São Paulo (Lenko, 1971). Santa Catarina: Blumenau, 
Pouso Redondo, Sombrio and Tubarão (Araujo \& Buckup, 1996a). Rio Grande do Sul: Fontoura Xavier and Porto Alegre (FZBRS) (ARAUjo \& BUCKUP, 1996a).

Remarks. The synonym list presented here includes the original description and the papers mentioning Brazil. The complete list is available in SchMALfuss (2003).

Distribution. Circumtropical species. In Brazil this species is considerade to be introduced and it is recorded from the states of Pará, Bahia, Minas Gerais, Espírito Santo, Rio de Janeiro, São Paulo to Rio Grande do Sul.

Trachelipodidae

Nagurus Holthuis, 1949

Nagurus cristatus (Dollfus, 1889)

Porcellio cristatus Dollfus, 1889:91, pl. V, figs 2a-d.

Nagurus cristatus; Lemos de CASTRO, 1967:323, 1971:7, fig. 7; ViLELA et al., 1971:184, figs 1-4; Araujo \& BuCKuP, 1996b:161, figs 1 and 3; SOUZA-KuRY, 1998:668

Material examined. BRAZIL, Bahia: many $\delta$ and ㅇ, Camamu, 1356'59”'S, 3906'27’'W, 18.IX.2013, I. S. Campos-Filho \& J. T. Lisboa col. (UFRGS 5780).

Remarks. The synonym list presented here includes the original description and the works mentioning Brazil. The complete list is available in Schmalfuss (2003).

Previous Brazilian records. Pará: Belém (Várzea do Guamá and Park of MPEG), Castanhal, and Peixe-Boi (Lemos de Castro, 1967). São Paulo and Rio de Janeiro (Lemos de Castro, 1971). Mato Grosso: Dourados (Vilela et al., 1971). Santa Catarina: Gravatal, Major Gerciano, Nova Teutônia and Pouso Redondo (Araujo \& BuCKuP, 1996b).

Distribution. Circumtropical. In Brazil, this species is recorded from the states of Mato Grosso, Pará, Rio de Janeiro, São Paulo and Santa Catarina.

\section{Nagurus nanus (Budde-Lund, 1908)}

Porcellio (Nagara) nana Budde-Lund, 1908:285, taf. 14, figs 40-47. Nagurus nanus; ARAUJo \& BUCKUP, 1996b:161, figs 2, 3.

Material examined. BRAZIL, Santa Catarina: $5 \hat{\jmath}$, 3ㅇ, São João Batista, $27^{\circ} 15^{\prime} 52^{\prime \prime}$ 'S , 48 $51^{\prime}$ '12”W, 26.VI.2012, P. B. Araujo \& B. L. Zimmermann col., in woods (UFRGS 5598).

Previous Brazilian records. Santa Catarina: Gravatal (Araujo \& Buckup, 1996b).

Remarks. The synonym list presented here includes the original description and the works mentioning Brazil. The complete list is available in SchmaLfuss (2003).

Distribution. Tropical and subpropical areas. In Brazil this species is recorded only from the state of Santa Catarina.

Armadillidiidae Armadillidium Brandt, 1833 Armadillidium vulgare (Latreille, 1804)

Armadillo vulgaris Latreille, 1804:48.
Armadillidium vulgare; Lemos de Castro, 1971:4, fig 14; LenKo, 1971:8; Araujo et al., 1996:133, figs 54-58, 68; Souza-KurY, 1998:654; Leistikow \& WäGele, 1999:43; Araujo, 1999:252, fig. 23; Schmalfuss, 2003:38; Appel et al., 2011:124, figs 1B, 2D-F; CAMPos-FilHo et al., 2014:412, fig. 40.

Material examined. BRAZIL, Minas Gerais: many

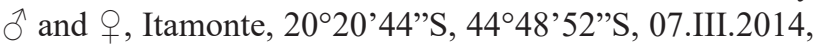
G. M. Cardoso col. (UFRGS 5909). São Paulo: ㅇ, Campos

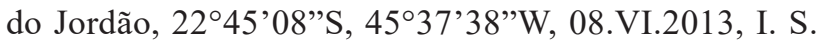
Campos-Filho \& G. M. Cardoso col., Pinus and Araucaria forest (UFRGS 5855). Rio Grande do Sul: $\partial$, Fontoura Xavier, $29^{\circ} 0^{\prime} 17^{\prime}$ 'S, $52^{\circ} 21^{\prime} \mathrm{W}, 27 . \mathrm{VII} .2013$, G. M. Cardoso col. (UFRGS 5726).

Previous Brazilian records. Bahia, Minas Gerais, São Paulo, Rio de Janeiro and Rio Grande do Sul (Lemos DE CASTRO, 1971). Minas Gerais: São Roque de Minas, Serra da Canastra, Gruta Zeferino I cave (CAmpos-Filho et al., 2014). São Paulo: Barueri, Cidade Universitária (São Paulo city), and Salesópolis (E. E. da Boracéia) (LenKo, 1971). Santa Catarina: Anchieta, Blumenau, Bom Retiro, Campos Novos, Catanduvas, Faxinal dos Guedes, Florianópolis, Itá, Joaçaba, Lages, Mondaí, Ponte Serrada, São Miguel d'Oeste, São Lourenço d'Oeste, Santa Cecília, Sombrio, Urussanga, and Xanrerê (Araujo et al., 1996). Rio Grande do Sul: Agudo, Arroio Grande, Bagé, Caçapava do Sul, Camaquã, Capão da Canoa, Casca, Caxias do Sul, Coronel Bicaco, Dom Pedrito, Encruzilhada do Sul, Erechim, Flores da Cunha, Garibaldi, Iraí, Mata, Nhu-Porã, Otávio Rocha, Palmeira das Missões, Panambi, Pantano Grande, Passo Fundo, Pinheiro Machado, Porto Alegre, Rio Grande (E. E. Taim), Rio Pardo, Rosário do Sul, São Borja, São Francisco, São Gabriel, São Lourenço do Sul, São Luiz Gonzaga, São Vicente do Sul, Santa Cruz do Sul, Santa Isabel do Sul, Santa Maria, Santa Rosa, Santana do Livramento, Santiago, Santo Ângelo, Sarandi, Tapes, Taquara, Tramandaí, Três Passos, Veranópolis (ARAUjo et al., 1996).

Remarks. The synonym list presented here includes the original description and the works mentioning Brazil. The complete list is available in Schmalfuss (2003).

Distribution. Mediterranean species introduced into many parts of the world.

\section{Eubelidae \\ Ethelum Budde-Lund, 1899 \\ Ethelum americanum (Dolfuss, 1896)}

Mesarmadillo americanus DolLfus, 1896:397, figs 11a-d; RICHARDSON, 1901:573.

Ethelum americanum; BUdDE-Lund, 1899: 90, pl. III, figs 10-12; Richardson, 1905:589, figs 649, 650; PeArse, 1917, pl. 1; VAN NAME, 1925:484, figs 27-36; Paulian de Félice, 1944:145; Lemos de Castro, 1967:312; SouZa-Kury, 1998:657, LeISTIKow \& WäGele, 1999:42; SCHMALFUSS, 2003:95.

Material examined. BRAZIL, Pará: $\widehat{O}$ (part in micropreparations), Belém, MPEG, Campus de pesquisa, 11.IV.2014, J.T. Lisboa col., under tree barks, in front of the restaurants (MZUF 9650). 
Previous Brazilian records. Pará: Apeú, Castanhal (Lemos de Castro, 1967).

Distribution. Lesser Antilles, northern Brazil (state of Pará), French Guiana, Guyana, and northern Venezuela.

Armadillidae

Ctenorillo Verhoeff, 1942

Ctenorillo tuberosus (Budde-Lund, 1904), comb. nov.

$$
\text { (Figs 74-97) }
$$

Armadillo tuberosus BudDE-Lund, 1904:109, pl. X, figs 1-4. Reductoniscus tuberosus; KeSSELYAK, 1930:61; LeMos de CASTRO, 1972:357. Cubaris tuberosa VAN NAME, 1936:377, fig. 288, 1940:134.

Venezillo tuberosus; Souza-KuRY, 1998:654; LeISTIKow \& WäGELE, 1999:51; JEPPESEN, 2000: 262; SCHMALFUSS, 2003:293.

Material examined. BRAZIL, Ceará: $3 \hat{\partial}, 5$ 옹 Fortaleza, Campus Pici, 29.V.2013, F. B. Ribeiro col., in cashew tree (MZUF 9651).

Previous Brazilian records. Bahia: Abrolhos Archipelagous (Lemos DE CASTRO, 1972).

Redescription. Maximum body length: $\widehat{\delta} 2.5 \mathrm{~mm}$, o $3.5 \mathrm{~mm}$. Color brown. Endoantennal conglobation (Figs $74,78)$. Dorsum covered with large ribs and tubercles, arranged as follows (Fig. 75): vertex of cephalon with one anterior row of six tubercles and one posterior row of four tubercles; pereonites 1-7 with many tubercles and ribs as in Figs 74, 75; pleonites 3 and 4 with one row of four tubercles, pleonite 5 and telson with two paramedian tubercles each. Dorsal surface with short triangular scale-setae (Fig. 76). Pereonites 1-7 with one nodulus lateralis per side inserted on lateral surface of the second outer tubercle (Fig. 74). Cephalon (Figs 77, 78) with frontal shield slightly protruding above vertex and concave in middle; eyes of about 10 ommatidia. Pereonite 1 grooved on lateral margin for about twothirds of its length, inner lobe of schisma rounded, not extending beyond posterior margin of outer lobe (Figs 78, 79). Pereonite 2 with triangular ventral lobe not extending beyond posterior margin of epimeron (Fig. 78). Pereonites 2-7 with quadrangular epimera (Fig. 74). Telson (Figs 80,81 ) hourglass-shaped, proximal part broader than distal part, distal margin slightly convex. Antennula (Fig. 82) of three articles with three apical and two subapical aesthetascs. Antenna (Fig. 83) short and stout, slightly surpassing rear margin of cephalon; flagellum with second article about twice as long as first; apical organ about $1 / 3$ as long as second article of flagellum. Mandible (Figs $84,85)$ with molar penicil dichotomized, consisting of several plumose setae; left mandibles with $2+1$ and right mandible with $1+1$ free penicils. Maxillula (Fig. 86) with outer branch bearing $4+4$ simple teeth; inner branch with two long penicils. Maxilla (Fig. 87) bilobate, inner lobe distinctly narrower than outer lobe. Maxilliped (Fig. 88) endite with subapical large seta overpassing distal margin, two short triangular spines distally; palp with two setae on the basal article. Pleopods 1-5 with monospiracular respiratory structures. Uropod (Fig. 89) protopod flattened, enlarged on basal part, distal part trapezoidal, with medial margin slightly concave; exopod very short, inserted dorsally near medial margin of protopod.

Male: Pereopod 1 and 7 (Figs 90, 91) with no particular modifications. Genital papilla as in Fig. 92. Pleopod 1 (Fig. 93) exopod small, wider than long, distal portion triangular, outer margin concave and crenulate; endopod with distal portion slightly bent outwards and slightly swollen. Pleopod 2 (Fig. 94) exopod triangular, with outer margin distinctly concave; endopod longer than exopod. Pleopod 3-5 exopods as in Fig. 95-97.

Remarks. This species was described by BuDDELund (1904) as Armadillo tuberosus from Port au Prince, Haiti. It was later included in Reductoniscus by KesselyaK (1930) and then in Cubaris by (VAN Name, 1936). The examination of the specimens from Brazil, certainly belonging to this species, showed that it belongs to Ctenorillo as redefined by Schmalfuss \& FerRara (1983), of which the genus Tuberdillo Arcangeli, 1941, is a junior synonym (see TAITI et al., 1998). In fact, it has the cephalon, pereon, pleon and telson with developed costae and tubercles; the cephalon with the frontal lamina protruding above the vertex; pereon, pleon epimera and telson obliquely bent outward; pereonite 1 with schisma; ventral lobe of pereonite 2 tooth-shaped; epimera of pereonites 2-7 rectangular; telson hour-glass-shaped with basal part with two paramedial tubercles and distal part bent outwards with apex truncate; antenna short and thickset; uropod with tiny exopodite.

To date Ctenorillo included 13 species (Schmalfuss, 2003; CAMPos-FilHo et al., 2014): C. ausseli (Dollfus, 1893), from the Canary Islands; C. bananae (Van Name, 1920), from Cameroon, Congo and Angola; C. buddelundi Verhoeff, 1942, from Uganda and Kenya; C. fagei (Paulian de Félice, 1941), from Ivory Coast; C. ferrarai Campos-Filho, Araujo \& Taiti, 2014 from Brazil; C. gabunensis (Schmalfuss \& Ferrara, 1983), from Gabon; C. guinensis (Schmalfuss \& Ferrara, 1983), from Guinea; C. kenyensis Schmölzer, 1974, from Uganda and Tanzania; C. legai (Arcangeli, 1941), from Ethiopia; C. mineri (Van Name, 1936), from Venezuela and Guyana; C. parituberculatus (Taiti \& Ferrara, 1987), from Malawi; C. regulus (Van Name, 1920), from Zaire and Somalia; and C. strinatii (Schmalfuss \& Ferrara, 1983), from Congo. The species of the genus are mainly distinguished by the number and disposition of dorsal tubercles. In having four tubercles on pleonites 3 and 4 and two on pleonite 5 and telson, C. tuberosus resembles C. gabunensis, from which it differs in the number and disposition of tubercles on the cephalon and pereon (compare Fig. 75 with Fig. 154 in SCHMALFUSS \& FERRARA 1983).

Distribution. Haiti, St. Thomas Island, and Brazil (state of Bahia). It is also recorded from the Botanical Garden, Dahlem, near Berlin (KesSelYaK, 1930; VAn NAME, 1936). 

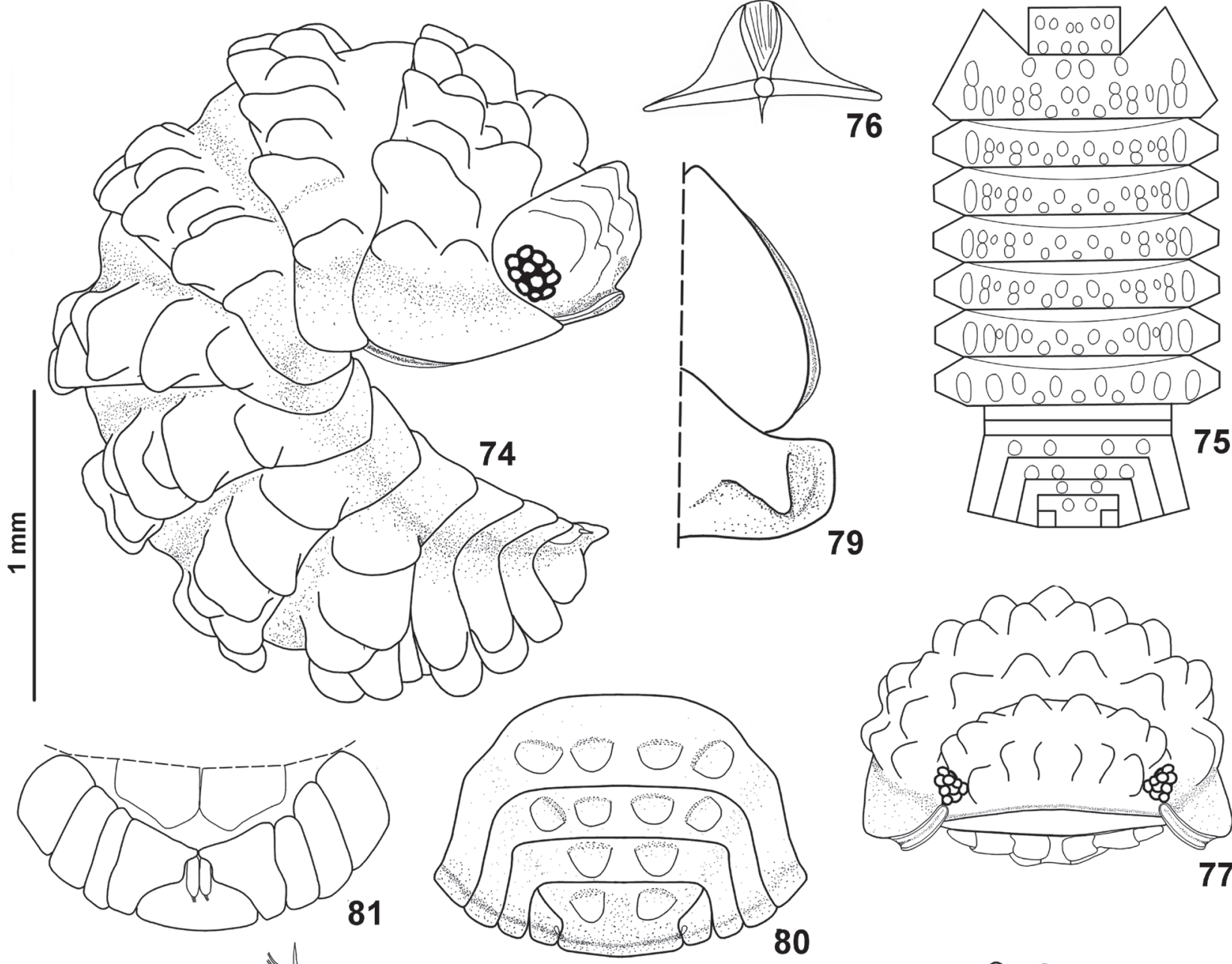

79
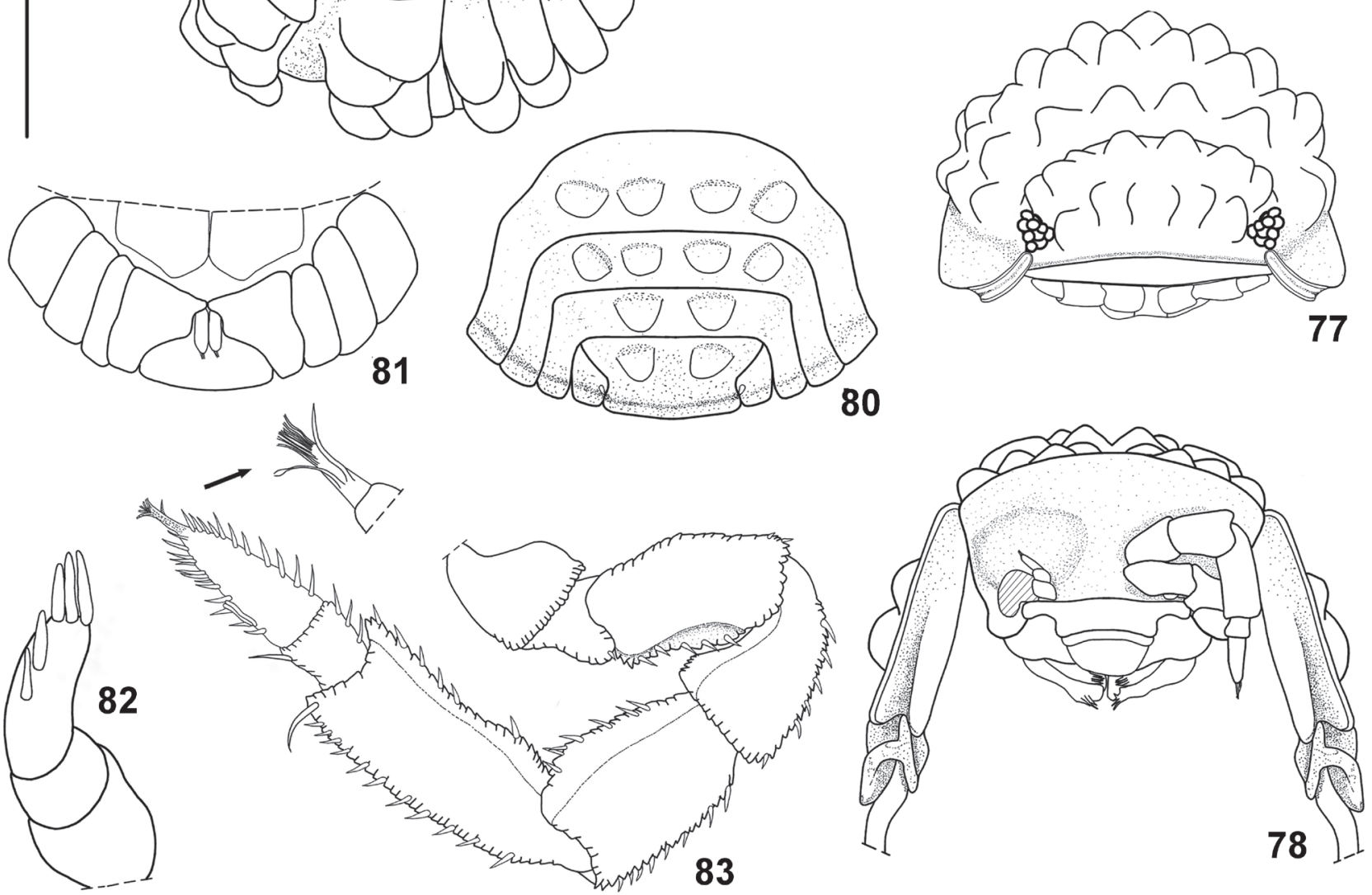

Figs 74-83. Ctenorillo tuberosus (Budde-Lund, 1904), §̊: 74, adult specimen, lateral view; 75, disposition of dorsal tubercles; 76, dorsal scale-seta; 77, cephalon and pereonites 1, dorsal view; 78, cephalon and pereonites 1 and 2, frontal view; 79, epimera of pereonites 1 and 2, ventral view; 80, pleonites 3-5, telson and uropods, dorsal view; 81, pleonites 3-5, telson and uropods, ventral view; 82, antennula; 83, antenna.

Cubaris Brandt, 1833

Cubaris murina Brandt, 1833

Cubaris murina BrandT, 1833:190; Lemos de CASTRO, 1967:328; 1971:12, fig. 13; Vilela et al., 1971:184; Araujo et al., 1996:129, figs 46-47; SOUZA-KuRY, 1998:653; Leistikow \& WäGele, 1999:44; SChMALFuss, 2003:81; NIEMEYER et al., 2006:14; 2009:138; NiEMEYER \& DA SiLVA,
2006:18; ApPel et al., 2011:124, fig. 2B, C; CAMPOS-FilHO et al., 2014:417, fig. 40; Zimmermann et al., 2015b:3, table 1.

Material examined. BRAZIL, Espírito Santo: many $\sigma^{\lambda}$ and $\circ$, Linhares, $19^{\circ} 25^{\prime} 45^{\prime}$ 'S, $40^{\circ} 05^{\prime} 12^{\prime}$ 'W, 11.III.2014, G. M. Cardoso col. (UFRGS 5971). Mato Grosso do Sul: 
$3{ }^{\lambda}, 2$, 1 manca, Bonito, Bonito HI-Hostel, 21 ${ }^{\circ} 07^{\prime} 22^{\prime \prime}$ S, 56 30'06”'W, 12.XI.2014, G. M. Cardoso col. (UFRGS 6011); $2{ }^{\lambda}, 3$, Jardim, RPPN Rio da Prata, $21^{\circ} 27^{\prime} 41^{\prime \prime}$, $56^{\circ} 26^{\prime} 23^{\prime}$ 'W, 13.XI.2014, G. M. Cardoso col. (UFRGS 6014).

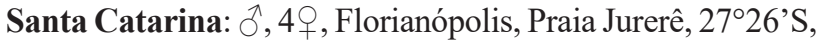
$48^{\circ} 29^{\prime} \mathrm{W}$, 04.III.2005, P. B. Araujo col. (UFRGS 6475)

Previous Brazilian records. Pará: Arapera (LEMOS DE CASTRO, 1967). Pará, Bahia, Minas Gerais, Espírito Santo, Rio de Janeiro and São Paulo (Lemos DE CASTRO, 1971). Bahia: Simões Filho (NIEMEYER et al., 2006, 2009; NIEMEYER \& DA SiLva, 2006); Gruta dos Brejões, Morro do Chapéu (CAmposFilho et al., 2014). Mato Grosso: Dourados (Vilela et al., 1971). Santa Catarina: Blumenau and Timbó (ARAUjo et al., 1996). Paraná: Foz do Iguaçu (ZimmERmann et al., 2015b).

Remarks. The synonym list presented here includes the original description and the works mentioning Brazil. The complete list is available in Schmalfuss (2003).

Distribution. Circumtropical. In Brazil, this species is recorded from the states of Pará, Bahia, Mato Grosso, Mato Grosso do Sul, Espírito Santo, Paraná and Santa Catarina.

\section{Diploexochus Brandt, 1833 \\ Diploexochus echinatus Brandt, 1833}

(Figs 98-122)

Diploexochus echinatus Brandt, 1833:192, pl. IV, figs 20, 21; MilneEDWARDS, 1840:180; BUDDE-LuND, 1909:54; RICHARDSON, 1912:479;
ArCANGELI, 1934:92, 1957:101; VAN NAME, 1936:398, figs 241-243; Lemos de CASTRO, 1967:322; SoUZA-KuRY, 1998:6532; LeISTIKOW \& WÄGELE, 1999:44; SCHMALFuss, 2003:90.

Armadillo echinatus; BudDE-Lund, 1879:7; 1885:26, 1904:104, pl. IX figs 35-37.

Cubaris echinatus; Pearse, 1917:3.

Cubaris gaigei PeARse, 1917:2, fig. 1; VAN NAME, 1925:467.

Material examined. FRENCH GUIANA: $\hat{\jmath}, 3$, RN Nouragues, Saint Pararé, 4.VII.2010, S. E. A. G. col. (MZUF 9653). BRAZIL, Pará: $3 \hat{\jmath}, 3$, 3 juveniles, FLONA Caxiuanã, 25.VIII.2012, E. G. Cafofo col. (MZUF 9652).

Previous Brazilian records. Pará: Acará and Belém (Ilha do Marajó) (Lemos De CASTRo, 1967).

Redescription. Maximum body length: ơ $9 \mathrm{~mm}$, q $9.5 \mathrm{~mm}$. Color dark brown. Endoantennal conglobation (Fig. 98). Dorsum covered with large triangular and acute tubercles, arranged as follows (Fig. 99): vertex of cephalon with 12 tubercles in three rows; pereonite 1 with 24 tubercles; pereonites 2-6 with 15 tubercles; pereonite 7 with 13 tubercles; pleonites 3 and 4 with one row of four tubercles, pleonite 5 and telson with two paramedian tubercles each. Dorsal surface with short semi-circular scale-setae (Fig. 100). Cephalon (Figs 101-103) with frontal shield prominent, distinctly protruding above vertex; eye with about 20 ommatidia. Pereonites with epimera flattened and directed outwards; pereonite 1 strongly grooved on lateral margin, inner lobe of schisma rounded, slightly extending beyond posterior

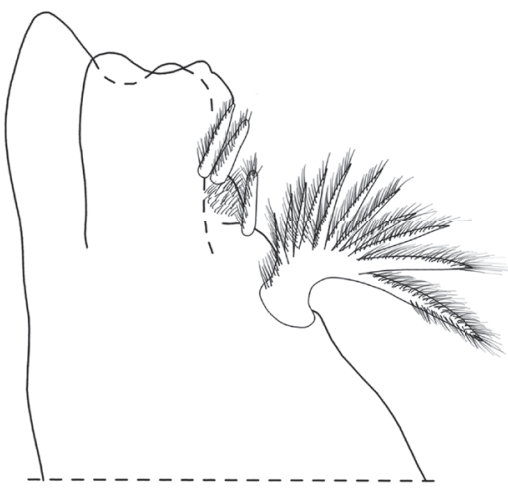

84

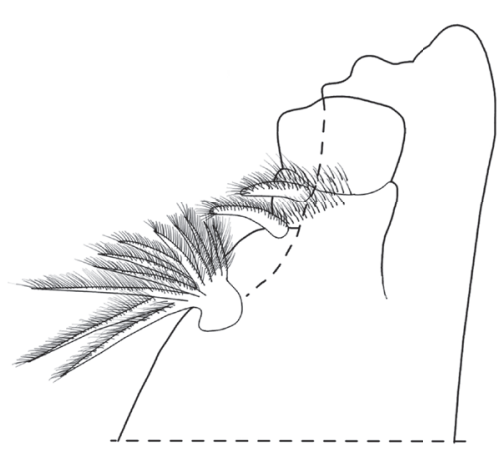

85

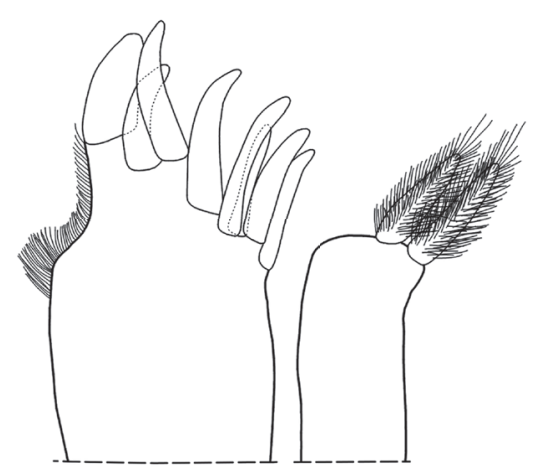

86

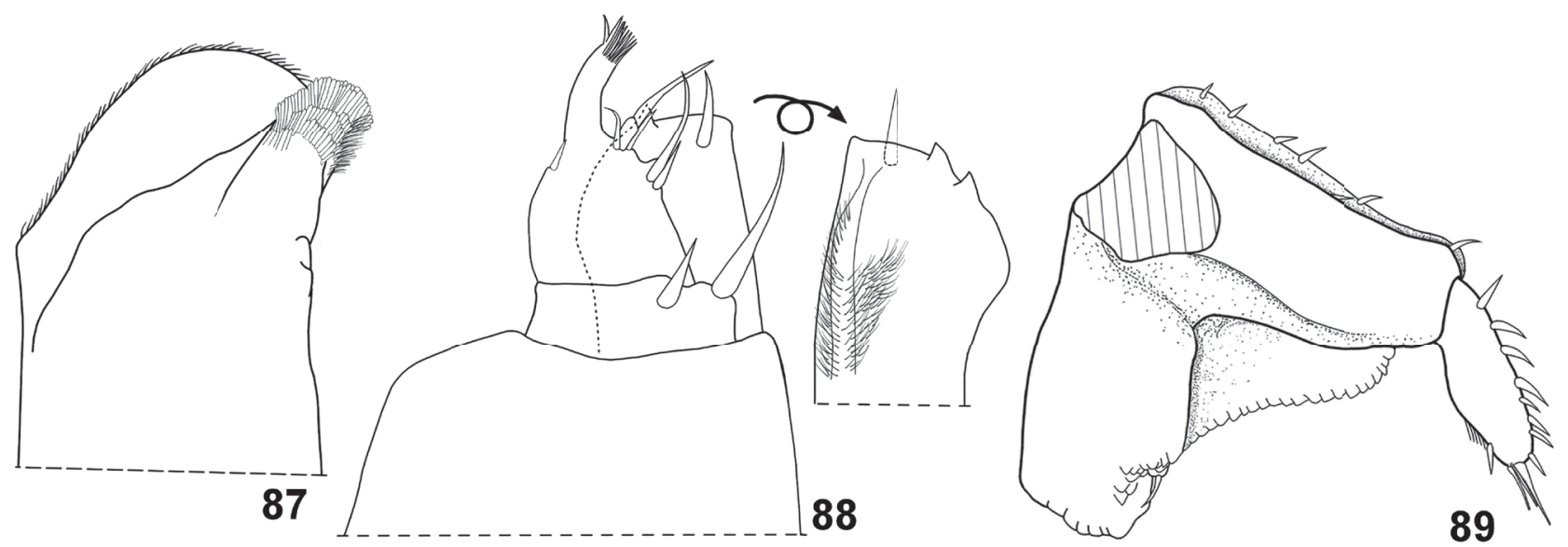

Figs 84-89. Ctenorillo tuberosus (Budde-Lund, 1904), ỗ: 84, left mandible; 85, right mandible; 86, maxillula; 87, maxilla; 88, maxilliped; 89, uropod. 


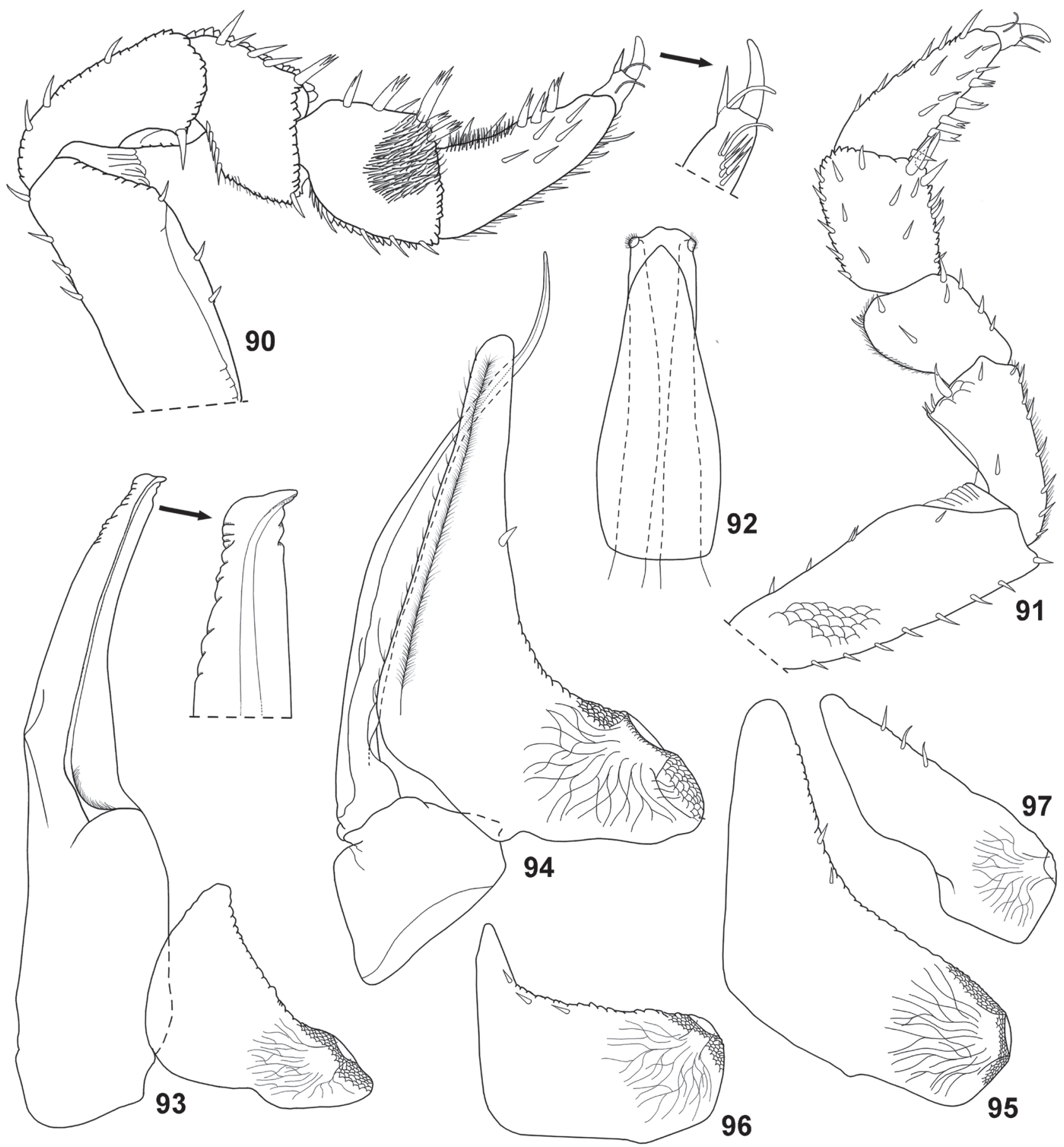

Figs 90-97. Ctenorillo tuberosus (Budde-Lund, 1904), ô: 90, pereopod 1; 91 pereopod 7; 92, genital papilla; 93, pleopod 1; 94, pleopod 2; 95, pleopod 3 exopod; 96, pleopod 4 exopod; 97 , pleopod 5 exopod.

margin of outer lobe (Figs 103, 104), pereonite 2 with triangular ventral lobe; pereonite 3 with small rounded ventral lobe; pereonites 5-7 with oblique ventral ridge (Fig. 104). Pleonites 3-5 (Figs 105, 106) with epimera well developed, quadrangular slightly directed outwards. Telson quadrangular, proximal part broader than distal part, dorsum slightly depressed, distal margin concave. Antennula (Fig. 107) of three articles, proximal and distal articles subequal in length, distal article with many aesthetascs inserted apically and subapically. Antenna (Fig. 108) short, not surpassing rear margin of pereonite 1; flagellum of two articles, distal article about three times as long as first bearing two rows of two aesthetascs. Mandible (Figs 109, 110) with molar penicil simple; left mandibles with $2+1$ and right mandible with $1+1$ free penicils. Maxillula (Fig. 111) outer branch with $4+6$ simple teeth; inner branch with two stout penicils. 

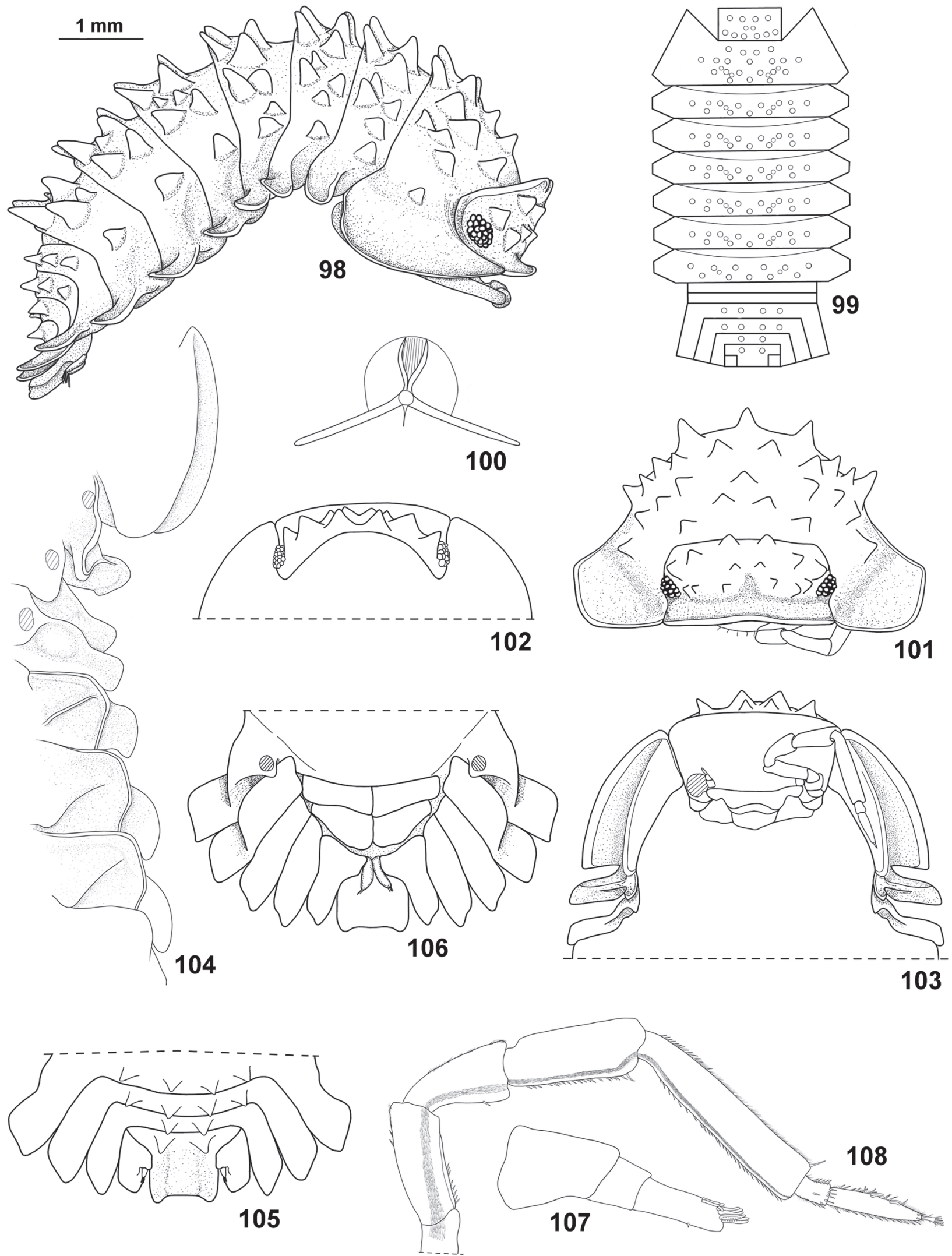

Figs 98-108. Diploexochus echinatus Brandt, 1833, đ̇: 98, adult specimen, lateral view; 99, disposition of dorsal tubercles; 100, dorsal scale-seta; 101, cephalon and pereonite 1, dorsal view; 102, cephalon and pereonites 1, caudal view; 103, cephalon and pereonites 1-3, frontal view; 104, epimera of pereonites 1-7, ventral view; 105, pleonites 3-5, telson and uropods, dorsal view; 106, pleonites 3-5, telson and uropods, ventral view; 107, antennula; 108 , antenna. 


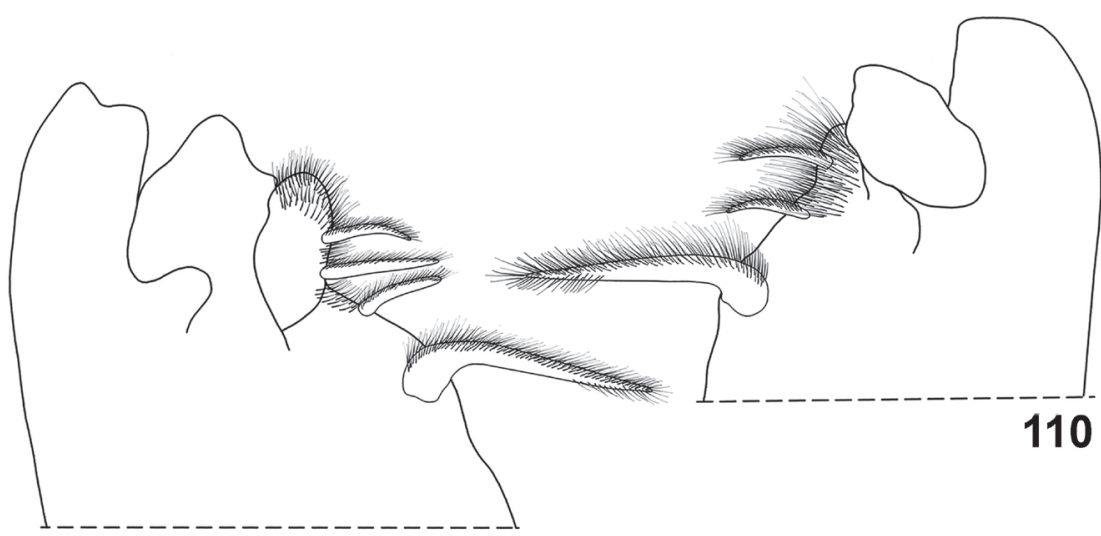

109

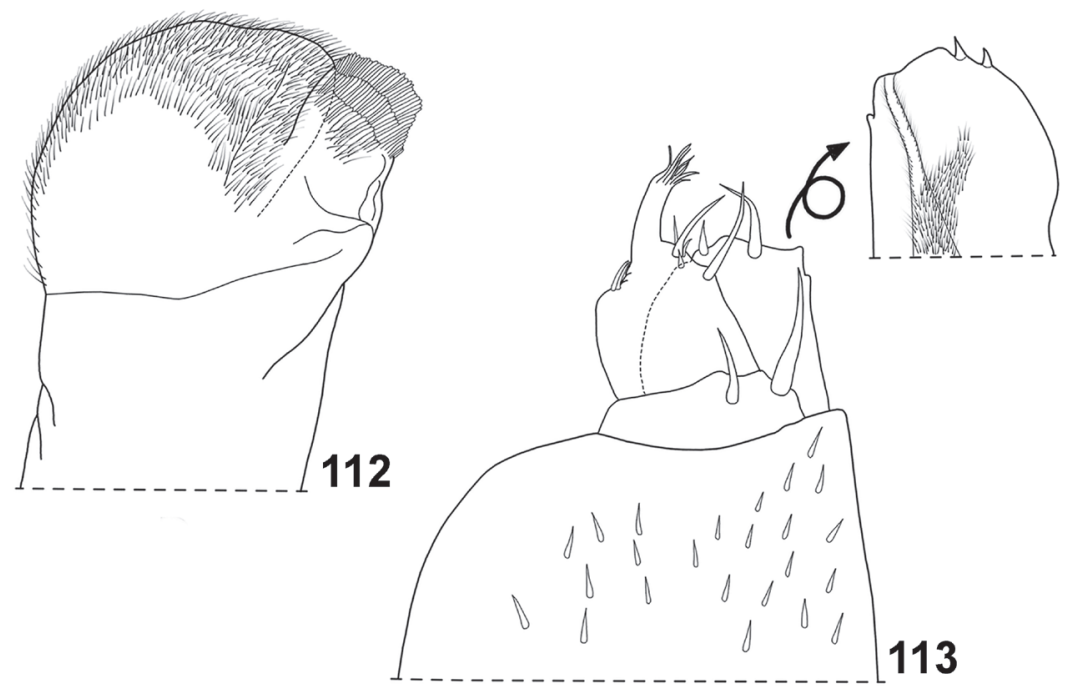

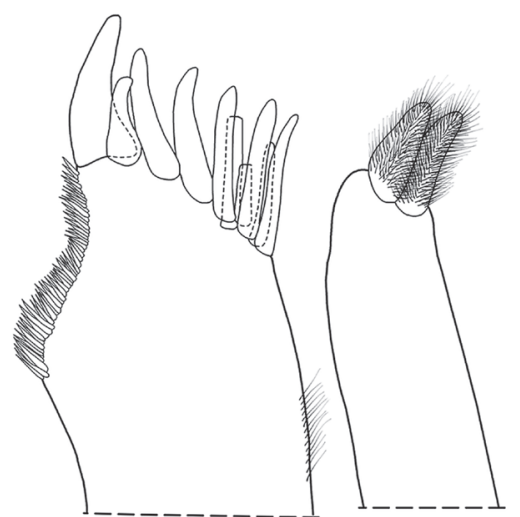

111

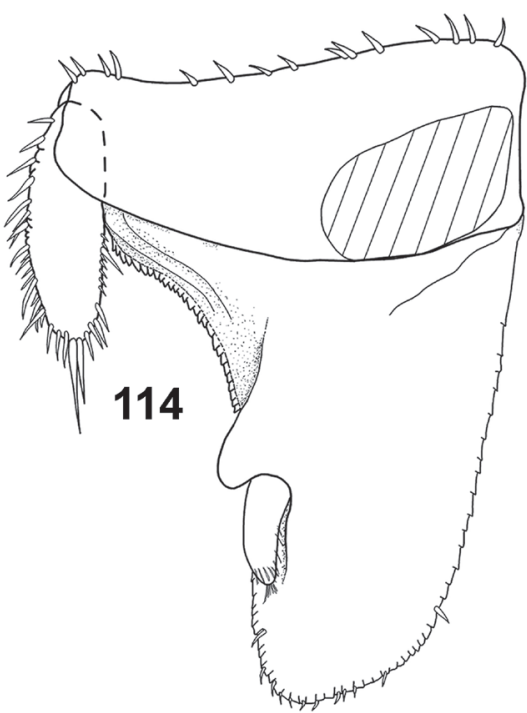

Figs 109-114. Diploexochus echinatus Brandt, 1833, ふ̊: 109, left mandible; 110, right mandible; 111, maxillula; 112, maxilla; 113, maxilliped; 114, uropod.

Maxilla (Fig. 112) bilobate, outer lobe three times as wide as inner lobe, covered with thin setae, inner lobe covered with thick setae. Maxilliped (Fig. 113) endite with medial seta overpassing distal margin, distal margin slightly rounded with two short triangular setae; palp with two setae on basal article. Pleopods $1-5$ with monospiracular respiratory structures. Uropod (Fig. 114) protopod flattened, enlarged on basal part, distal part subrectangular, medial margin slightly concave; exopod short inserted dorsally near medial margin below distinct lobe.

Male: pereopods 1 and 7 (Figs 115, 116) with no particular modifications. Genital papilla as in Fig. 117. Pleopod 1 (Fig. 118) exopod small, triangular, wider than long, outer and inner margin with many setae; endopod about three times as long as exopod, distal part slightly bent outwards. Pleopod 2 (Fig. 119) exopod triangular, outer margin strongly concave bearing many setae; endopod slightly longer than exopod. Pleopod 3-5 exopods as in Fig. 120-122.
Remarks. Diploexochus was erected by BRANDT (1833) to allocate D. echinatus from Brazil. To date, the genus includes with certainty only the type-species (SCHMALFuss, 2003).

Distribution. Guyana, French Guiana, Trinidad and Brazil (state of Pará).

Acknowledgments. We are grateful to Dr Marcos Tavares and Maria José from MZUSP for the assistance in material deposit; to ICMBio (Instituto Chico Mendes de Conservação da Biodiversidade), SisBio (Sistema de Autorização e Informação em Biodiversidade) for the license to collect (license number 25716); to CNR, ISE (Consiglio Nazionale delle Ricerche, Istituto per lo Studio degli Ecosistemi, Sesto Fiorentino, Florence, Italy) for hosting ISC-F during his postdoctoral; to $\mathrm{CNPq}$ (Conselho Nacional de Desenvolvimento Científico e Tecnológico) for the Ph.D. and postdoctoral scholarships granted to ISC-F (MCT/CNPq/MEC/ CAPES/PROTAX 562202/2010-2 and PDE 204468/2014-0) and productivity fellowship to PBA; to CAPES (Coordenação de Aperfeiçoamento de Pessoal de Ensino Superior) for the PNPD scholarship to ISC-F (CAPES/PNPD/ UFCG/CTRN/PPGRN/201713705-5). 


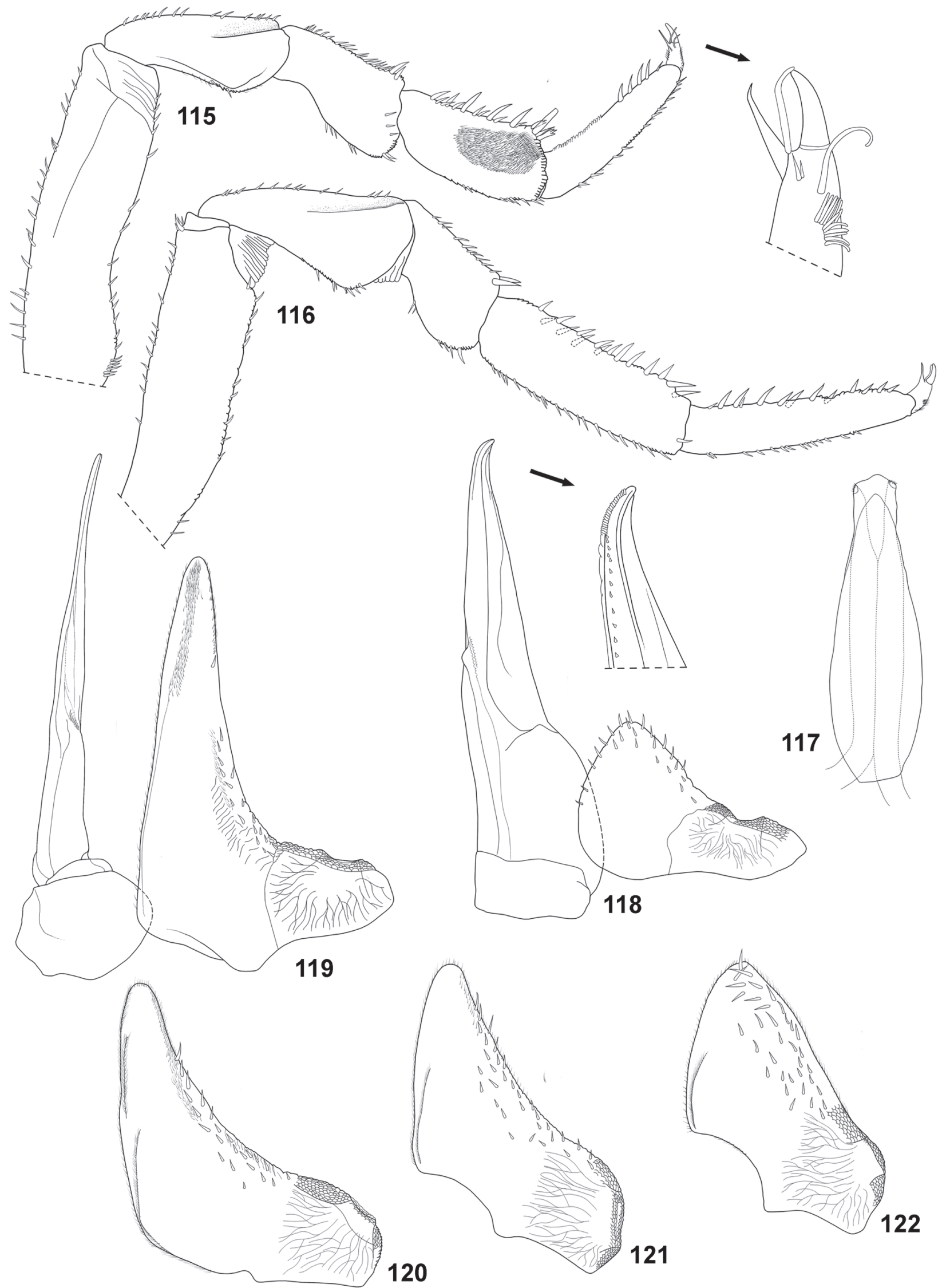

Figs 115-122. Diploexochus echinatus Brandt, 1833, ð̊: 115, pereopod 1; 116, pereopod 7; 117, genital papilla; 118, pleopod 1; 119, pleopod 2; 120, pleopod 3 exopod; 121, pleopod 4 exopod; 122, pleopod 5 exopod. 


\section{REFERENCES}

Almerão, M. P.; Fagundes, N. J. R.; Araujo, P. B.; Verne, S.; Grandjean, F.; Bouchon, D. \& AraúJo, A. M. 2012. First record of Wolbachia in South American terrestrial isopods: prevalence and diversity in two species of Balloniscus (Crustacea, Oniscidea). Genetics and Molecular Biology 35(4):980-989.

Almerão, M. P.; Mendonça, M. de S.; Quadros, A. F.; Pedó, E.; Silva, L. G. R. \& Araujo, P. B. 2006. Terrestrial isopod diversity in the subtropical Neotropics: Itapuã State Park, southern Brazil. Iheringia, Série Zoologia 96(4):473-477.

Appel, C.; Quadros, A. F. \& Araujo, P. B. 2011. Marsupial extension in terrestrial isopods (Crustacea, Isopoda, Oniscidea). Nauplius 19(2):123-128.

Araujo, P. B. 1999. Subordem Oniscidea (Isópodos terrestres, "tatuzinhos". In: Buckup, L. \& Bond-Buckup, G. eds. Os crustáceos do Rio Grande do Sul. Porto Alegre, Ed. Universidade/UFRGS, p. 237-256

Araujo, P. B.; Augusto, M. M. \& Bond-Buckup, G. 2004a. Postmarsupial development of Atlantoscia floridana (van Name, 1940) (Crustacea, Isopoda, Oniscidea): the manca stages. Journal of Natural History 38:951-965.

Araujo, P. B. \& Bond-Buckup, G. 2004. Growth curve of Atlantoscia floridana (van Name) (Crustacea, Isopoda, Philosciidae) from a Brazilian Restinga Forest. Revista Brasileira de Zoologia 21:1-8.

Araujo, P. B. \& Bond-Buckup, G. 2005. Population structure and reproductive biology of Atlantoscia floridana in Southern Brazil (Crustacea, Isopoda). Acta Oecologica 28:289-298.

Araujo, P. B. \& Buckup, L. 1996a. Novos registros e uma espécie nova de Trichorhina Budde-Lund (Isopoda, Oniscidea, Platyarthridae) do Sul do Brasil. Revista Brasileira de Zoologia 13(3):799-810.

Araujo, P. B. \& Buckup, L. 1996b. Ocorrência de Nagurus Holthuis, 1949 (Isopoda, Trachelipodidae) no Sul do Brasil. Nauplius 4:161-163.

Araujo, P. B. \& Bueno, A. 1998. Novos registros de isópodos terrestres do sul do Brasil: Porcellionidae e Trichoniscidae (Crustacea, Oniscidea). Nauplius 6:185-186

Araujo, P. B.; Buckup, L. \& Bond-Buckup, G. 1996. Isópodos terrestres (Crustacea, Oniscidea) de Santa Catarina e Rio Grande do Sul, Brasil. Iheringia, Série Zoologia 81:111-134

Araujo, P. B. \& Leistikow, A. 1999. Philosciids with pleopodal lungs from Brazil, with description of a new species (Crustacea, Isopoda). Contributions to Zoology 68(2):109-141.

Araujo, P. B. \& Quadros, A. F. 2005. A new species of Alboscia Schultz, 1995 (Crustacea: Isopoda: Oniscidea: Philosciidae) from Brazil. Zootaxa 1018:55-60.

Araujo, P. B.; Quadros, A. F.; Augusto, M. M. \& Bond-Buckup, G. 2004b. Postmarsupial development of Atlantoscia floridana (Van Name, 1940) (Crustacea, Isopoda, Oniscidea): sexual differentiation and size at onset of sexual maturity. Invertebrate Reproduction and Development 45(3):221-230.

Araujo, P. B. \& TAiti, S. 2007. Terrestrial isopods (Crustacea, Oniscidea) from Rocas Atoll, northeastern, Brazil. Arquivos do Museu Nacional 65(3):347-355.

Araujo, P. B. \& Zardo, C. M. L. 1995. Uma nova espécie de Balloniscus Budde-Lund (Crustacea, Isopoda, Balloniscidae) do Sul do Brasil. Revista Brasileira de Zoologia 12(4):785-790.

Arcangeli, A. 1931. Circoniscus bezzii Arc., nuova specie di isopodo terrestre del Brasile. Bollettino di Zoologia 11:115-122.

Arcangeli, A. 1934. Note di revisione sulla famiglia Armadillidae. Bollettino dei Musei di Zoologia ed Anatomia Comparata della Reale Università di Torino 44:83-119.

Arcangeli, A. 1941. Crustacea, Isopoda. In: Zavattari, E. ed. Missione biologica Sagan-Omo. Zoologia. 6. Myriapoda, Arachnida, Tardigrada, Crustacea, Mollusca. Rome, Reale Accademia d'Italia, Centro Studi per l'Africa Orientale Italiana. vol. 12, p.5-18.

Arcangeli, A. 1957. I generi Diploexochus, Venezillo, Paramardillo [sic] (crostacei isopodi terrestri). Bollettino dell'Istituto e Museo di Zoologia dell'Università di Torino 5:101-142.

ARCANGELI, A. 1961. Spigolature di critica sopra la posizione sistematica di alcuni Crostacei Isopodi terrestri. Bollettino di Zoologia 28:337-346.
BARNARD, K. 1932. Contribution to the fauna of South Africa. 11. Terrestrial Isopoda. Annals of the South African Museum 30:179-388.

BARNARD, K. 1958. Terrestrial isopods and amphipods from Madagascar. Mémoires de l'Institute Scientifique de Madagascar 12:67-111.

BARNARD, K. 1964. The terrestrial Isopoda and Amphipoda of the Mascarene Islands. Bulletin of the Mauritius Institute 6:49-60.

BRANDT, I. 1833. Conspectus Monographiae Crustaceorum Oniscodorum Latreillii. Byulleten Moskovskogo Obshchestva Ispytatelei Prirody 6:171-193.

Budde-Lund, G. 1879. Prospectus generum specierumque Crustaceorum Isopodum Terrestrium. Copenhagen, Imprimerie de Jørgensen \& Knudtzon. 10p

Budde-Lund, G. 1885. Crustacea Isopoda Terrestria per Familias et Genera et Species Descripta. Copenhagen, Nielsen \& Lydiche.

Budde-Lund, G. 1893. Landisopoder fra Venezuela, insamlede of Dr. F. Meinert. Entomologiske Meddelelser 4:111-129.

Budde-Lund, G. 1899. Eubelum. In: A revision of Crustacea Isopoda terrestria, with additions and illustrations. Copenhagen, H. Hagerup, p. 67-97.

Budde-Lund, G. 1904. Spherilloninae. Armadillo. In: A revision of Crustacea Isopoda terrestria, with additions and illustrations. Copenhagen, H. Hagerup, p. 33-144.

Budde-Lund, G. 1908. Isopoda von Madagaskar und Ostafrika mit Diagnosen verwandter Arten. In: VoELTZKow, A. ed. Reise in Ostafrika den Jahren 1903-1905, Wissenschaftliche Ergebnisse. Stuttgart, E. Schwenzerbartsche Verlagsbuchhandlung. vol. 2, p. 265-308.

Campos-Filho, I. S. \& Araujo, P. B. 2011a. New species of Benthana Budde-Lund, 1908 (Crustacea: Oniscidea: Philosciidae) from Paraná, Brazil. Zootaxa 2765:38-46.

Campos-Filho, I. S. \& Araujo, P. B. 2011b. Two new troglobitic species of Scleropactidae (Crustacea: Isopoda: Oniscidea) from Pará, Brazil. Nauplius 19(1):27-39.

Campos-Filho, I. S.; Araujo, P. B.; Bichuette, M. E.; Trajano, E. \& TAITI, S. 2014. Terrestrial isopods (Crustacea: Isopoda: Oniscidea) from Brazilian caves. Zoological Journal of the Linnean Society 172:360-425

Campos-Filho, I. S.; Bichuette, M. E. \& Taiti, S. 2016. Threee new species of terrestrial isopods (Crustacea, Isopoda, Oniscidea) from Brazilian caves. Nauplius 24:e2016001.

Campos-Filho, I. S.; Contreira, S. G. \& Lopes-Leitzke, E. R. 2012. A new species of Atlantoscia Ferrara \& Taiti, 1981 (Oniscidea: Philosciidae) from Rio Grande do Sul, Brazil. Nauplius 20(2):137-144.

Campos-Filho, I. S.; Costa, S. L. N. \& Araujo P. B. 2013b. Two new species of Benthana Budde-Lund, 1908 (Crustacea: Isopoda: Philosciidae) from Brazil. Tropical Zoology 26(1):1-14.

Campos-Filho, I. S.; Lisboa, J. T. \& Araujo, P. B. 2013a. Review of Atlantoscia Ferrara \& Taiti, 1981 (Crustacea: Isopoda: Oniscidea: Philosciidae) with new records and new species. Organisms, Diversity \& Evolution 13:463-483.

Campos-Filho, I. S.; Mise, K. M. \& Sessegolo, G. C. 2015b. A new species of Trichorhina Budde-Lund, 1908 (Isopoda: Oniscidea: Platyarthridae) from Paraná caves, southern Brazil. Nauplius 23(2):112-119.

Campos-Filho, I. S.; TAiti, S. \& Araujo, P. B. 2015a. Taxonomic revision of the genus Benthana Budde-Lund, 1908 (Isopoda: Oniscidea: Philosciidae). Zootaxa 4022:1-73

Cardoso, G. M.; Campos-Filho, I. S. \& Araujo, P. B. 2016. The genus Dubioniscus Vandel, 1963 (Oniscidea, Dubioniscidae) with descriptions of two new species from Brazil. Tropical Zoology 29(3):111-133.

Costa, S. L. N.; Campos-Filho, I. S. \& Araujo, P. B. 2014. New species and new records of Benthana Budde-Lund, 1908 (Isopoda: Oniscidea: Philosciidae) from southern Brazil. Papéis Avulsos de Zoologia 54(13):169-176.

DANA, J. D. 1852. On the classification of the Crustacea Choristopoda or Tetradecapoda. The American Journal of Science and Arts 14(2):297316.

Dollfus, A. 1889. Sur quelques isopodes du Musée de Leyde. Notes from the Leiden Museum 11:91-94.

Dollfus, A. 1893. Voyage de M. CH. ALLUAUD aux Iles Canaries (novembre 1189-juin 1890). Isopodes terrestres. Mémoires de la Société Zoologique de France 6:46-56. 
Dollfus, A. 1896. On West Indian terrestrial isopod crustaceans. Proceedings of the Zoological Society of London 1896:388-400.

Dollfus, A. 1898. Isopodes terrestres des Indes neerlandaises. In: WEBER, M. ed. Zoologische Ergebnisse einer Reise in Niederlandisch OstIndien. Leiden, E.J. Brill, p.357-381.

DufFey, E. 1964. The terrestrial ecology of Ascension Island. Journal of Applied Ecology 1:209-251.

Fernandes, C. S.; Batalha, M. A. \& Bichuette, M. E. 2016. Does the cave environment reduce functional diversity? PLoS ONE 11(3):e0151958.

Ferrara, F.; PaOli, P. \& TAiti, S. 1994. Philosciids with pleopodal lungs? The case of the genus Aphiloscia Budde-Lund, 1908 (Crustacea: Isopoda: Oniscidea), with description of six new species. Journal of Natural History 26(6):1231-1264.

Ferrara, F. \& TAITI, S. 1979. A check-list of terrestrial isopods from Africa (south of the Sahara). Monitore Zoologico Italiano, Nuova Serie, Supplemento 12:89-215.

Ferrara, F. \& Taiti, S. 1981. Terrestrial isopods from Ascension Island Monitore Zoologico Italiano, Nuova Serie, Supplemento 13:189-198.

Gallão, J. E. \& Bichuette, M. E. 2015. Taxonomic distinctness and conservation of a new high biodiversity subterranean area in Brazil. Anais da Academia Brasileira de Ciências 87(1):209-217.

Grangeiro, D. C. \& Christoffersen, M. L. 2010. A new species of Androdeloscia (Isopoda: Philosciidae) from the Brazilian Amazon. Revista Nordestina de Biologia 19(2):77-93.

Grangeiro, D. C. \& SouzA, L. A. 2006. First record of terrestrial crustaceans (Isopoda, Oniscidea) from Chapada do Araripe, Ceará state, Brazil. Cadernos de Cultura e Ciência 1:33-39.

Green, A.; Ferrara, F. \& Taiti, S. 1990. Terrestrial Isopoda from the Krakatau Islands, South Sumatra and West Java. Memoirs of the Museum of Victoria 50(2):417-436.

Gregory, S. J. 2014. Woodlice (Isopoda: Oniscidea) from the Eden Project, Cornwall, with descriptions of species new to Britain and poorly known British species. Bulletin of the British Myriapod and Isopod Group 27:3-26.

Harding, P. \& SutTon, S. 1985. Woodlice in Britain and Ireland: Distribution and habitat. Huntingdon, Institute of Terrestrial Ecology. $152 \mathrm{p}$.

Herold, W. 1931. Land-Isopoden von den Sunda-Inseln. Ausbeuten der Deutschen Limnologischen Expedition und der Sunda-Expedition Rensch. Archiv für Hydrobiologie, Supplement 9:306-93.

Hoese, B. 1981. Morphologie und Funktion des Wasserleitungssystems der terrestrischen Isopoden (Crustacea, Isopoda, Oniscoidea). Zoomorphology 98:135-167.

Holthuis, L. B. 1949. The Isopoda and Tainadacea of the Netherland, including the description of a new species of Limnoria. Zoologische Mededelingen 30:163-190.

JaVIDKAR, M.; CoOPER, S. J. B.; King, R. A.; Humphreys, W. F. \& Austin, A. 2015. Molecular phylogenetic analyses reveal a new southern hemisphere oniscidean family (Crustacea: Isopoda) with a unique water transport system. Invertebrate Systematics 29:554-577.

JavidKar, M.; King, R. A.; Cooper, S. J. B.; Humphreys, W. F. \& Austin, A. D. 2017. Taxonomy of Paraplatyarthrus Javidkar and King (Isopoda: Oniscidea: Paraplatyarthridae) with description of five new species from Western Australia, and comments on Australian Trichorhina BuddeLunde, 1908 (Platyarthridae). Zootaxa 4243(3):401-431.

JoHnson, C. 1986. Parthenogenetic reproduction in the philosciid isopod, Ocelloscia floridana (Van Name, 1940). Crustaceana 51(2):123-132.

JEPPESEN, P. 2000. Catalogue of terrestrial isopod taxa and type material described by Gustav Budde-Lund (Crustacea: Isopoda). Steenstrupia 25(2):221-265.

Kenne, D. C. \& Araujo, P. B. 2015. Balloniscus glaber (Crustacea, Isopoda, Balloniscidae), a habitat specialist species in a disturbed area of Brazil. Iheringia, Série Zoologia 105(4):430-438.

KesselyÁK, A. 1930. Über Isopoden. Zoologischer Anzeiger 91:50-66.

Kwon, D. H. \& TAITI, S. 1993. Terrestrial Isopoda (Crustacea) from southern China, Macao and Honk Kong. Stuttgarter Beiträge zur Naturkunde, Serie A 490:1-83.

Latreille, P. A. 1804. Famille Seconde. Cloportides; cloportides. In: Buffon, L. \& Sonnini, C. S. eds. Histoire naturelle générale et particulière des Crustacés et des Insectes. Paris, F. Dufart. vol.7, p. 25-49.
Leistikow, A. 1999. Androdeloscia gen. n., a new genus of South American terrestrial isopods with description of 13 new species (Crustacea: Oniscidea: "Philosciidae"). Revue Suisse de Zoologie 106:813-904.

LeISTIKOw, A. 2000. A new genus of Oniscidea from South America and a phylogenetic analysis of related genera (Crustacea: Isopoda: Oniscidea). Contributions to Zoology 69(3):179-196.

Leistikow, A. 2001. Phylogeny and biogeography of South American Crinocheta, traditionally placed in the family "Philosciidae" (Crustacea: Isopoda: Oniscidea). Organisms, Diversity \& Evolution 4:1-85.

Leistikow, A. \& Araujo, P. B. 2001. Morphology of respiratory organs in South American Oniscidea ("Philosciidae"). In: KENSLEY, B. \& BRUSCA, R. C. ed. Isopod systematics and evolution. Crustacean Issues 13:329-336.

Leistikow, A. \& WÄGele, J. W. 1999. Checklist of terrestrial isopods of the New World (Crustacea, Isopoda, Oniscidea). Revista Brasileira de Zoologia 16(1):1-72.

Lemos de CAstro, A. 1953. Fauna do Distrito Federal, VIII. Sôbre a ocorrência dos Gêneros 'Miktoniscus' e 'Cordioniscus' no Rio de Janeiro. (Isopoda, Trichoniscidae). Anais da Academia Brasileira de Ciência 25(4):527-534.

Lemos de CAStro, A. 1958a. On the systematic position of some American species of Philoscia Latreille (Isopoda, Oniscoidea). American Museum Novitates 13:10.

Lemos de Castro, A. 1958b. Revisão do gênero Benthana Budde-Lund, 1908 (Isopoda, Oniscidae). Arquivos do Museu Nacional 44:85-118.

Lemos de CAStro, A. 1967. Isópodos terrestres da Amazônia brasileira. Atas do Simpósio sôbre a Biota Amazônica 5:311-336.

Lemos de CAstro, A. 1971. Isopodos terrestres introduzidos no Brasil (Isopoda, Oniscoidea). Boletim do Museu Nacional, Nova Série, Zoologia 282:1-14.

Lemos de Castro, A. 1972. Contribuições ao conhecimento da fauna do Arquipélago de Abrolhos. 3. Isópodos terrestres. Anais da Academia Brasileira de Ciências 44:357.

Lemos de CAstro, A. 1973. Pudeoniscidae, família nova, com descrição de um gênero novo e três espécies novas de isópodos terrestres (Isopoda, Oniscoidea). Boletim do Museu Nacional, Nova Série, Zoologia 287:1-10.

Lemos de CAstro, A. 1976. Considerações sobre a sinonímia e a distribuição geográfica de Balloniscus sellowii (Brandt, 1833) (Isopoda, Balloniscidae). Revista Brasileira de Biologia 36:391-396.

Lemos de Castro, A. 1985. Considerações sobre Atlantoscia alceui Ferrara \& Taiti, 1981 (Isopoda, Oniscoidea, Philosciidae). Revista Brasileira de Biologia 45(3):417-422.

Lemos de Castro, A. \& Souza, L. A. 1986. Três espécies novas de isópodes terretres do gênero Prosekia Vandel da Amazônia Brasileira (Isopoda, Oniscoidea, Philosciidae). Revista Brasileira de Biologia 46(2):429438.

LENKO, K. 1971. Subsidios para o conhecimento dos isópodos inquilinos de formigas no Brasil (Isopoda, Oniscoidea). Revista Brasileira de Entomologia 15:1-10.

Lisboa, J. T.; Couto, E. C. G.; Santos, P. P.; Delabie, J. H. C. \& Araujo, P. B. 2013. Terrestrial isopods (Crustacea: Isopoda: Oniscidea) in termite nests (Blattodea: Termitidae) in a cocoa plantation in Brazil. Biota Neotropica 13(3):393-397.

Lopes, E. R. C.; Mendonça, M. De S.; Bond-Buckup, G. \& Araujo, P. B. 2005. Oniscidea diversity across three environments in an altitudinal gradient in northeastern Rio Grande do Sul, Brazil. European Journal of Soil Biology 41:99-107.

López-Orosco, C. M.; Carpio-Díaz, Y. M.; SuÁrez, G. R. N. \& CamposFilho, I. S. 2016. A new species and first record of Androdeloscia (Oniscidea: Philosciidae) from Colombia. Studies on Neotropical Fauna and Environment 52(1):1-7.

Magrini, M. J.; Araujo, P. B. \& Uehara-Prado, M. 2010. Crustacea, Isopoda, Oniscidea Latreille, 1802: new continent record and distribution extension in Brazil. Checklist 6(2):217-219.

Magrini, M. J.; Freitas, A. V. L. \& Uehara-Prado, M. 2011. The effects of four types of anthropogenic disturbances on composition and abundance of terrestrial isopods (Isopoda: Oniscidea). Zoologia 28(1):63-71.

Meinhardt, H.; Quadros, A. F. \& Araujo, P. B. 2007. Growth curve of Balloniscus glaber Araujo \& Zardo (Crustacea, Isopoda, Oniscidea) 
from Parque Estadual de Itapuã, Rio Grande do Sul, Brazil. Revista Brasileira de Zoologia 24(4):1108-1112.

Milne-Edwards, M. 1840. Ordre des isopodes. In: Histoire Naturelle des Crustacés, comprenant l'anatomie, la physiologie et la classficiation de ces animaux. Paris, Librairie Encyclopédique de Roret. Tome Troisième, p. 115-283.

Montesanto, G. 2015. A fast GNU method to draw accurate scientific illustrations for taxonomy. Zookeys 515:191-206.

Montesanto, G. 2016. Drawing setae: a GNU way for digital scientific illustrations. Nauplius 24:e2016017.

Moreira, C. 1927. Duas espécies novas de crustáceos isópodes terrestres do Brasil. Boletim Biológico (São Paulo) 10:194-200.

Moreira, C. 1931. Crustacés isopodes terrestres du Brésil. Bulletin de la Societé Zoologique de France 56:426-433.

Muchmore, W. 1957. Some exotic terrestrial isopods (Isopoda: Oniscoidea) from New York State. Journal of the Washington Academy of Sciences 47:78-83.

MuchMORE, W. 1964. New terrestrial isopods from the genus Miktoniscus from eastern United States (Crustacea: Isopoda: Oniscoidea). Ohio Journal of Sciences 64:51-57.

MulaIK, S. 1960. Contribución al conocimiento de los isópodos terrestres de Mexico (Isopoda, Oniscoidea). Revista del la Sociedad Mexican de Historia Natural 21:79-292.

MulaiK, S. \& MulaiK, D. 1942. New species and records of American terrestrial isopods. Bulletin of the University of Utah 32:1-23.

Niemeyer, J. C.; Santos, V. C.; Rodrigues, J. M. L. \& Da-Silva, E. M. 2006. Comportamento de Cubaris murina Brandt (Crustacea: Isopoda) em solo com glifosato: testes de fuga em laboratório. Jornal Brasileiro da Sociedade de Ecotoxicologia 1:13-16

Niemeyer, J. C. \& DA Silva, E. M. 2006. Efeitos na biomassa de Cubaris murina Brandt (Crustacea: Isopoda) expostos ao solo com glifosato em laboratório. Jornal Brasileiro da Sociedade de Ecotoxicologia 1:17-20.

Niemeyer, J. C.; Santos, V. C.; Araujo, P. B. \& Da Silva, E. M. 2009. Reproduction of Cubaris murina (Crustacea: Isopoda) under laboratory conditions and its use in ecotoxicity tests. Brazilian Journal of Biology 69(1):137-142

Paoli, P.; Ferrara, F. \& Taiti, S. 2002. Morphology and evolution of the respiratory apparatus in the family Eubelidae (Crustacea, Isopoda, Oniscidea). Journal of Morphology 253:272-289.

Patience, A. 1907. On a new British terrestrial isopod. Journal of the Linnean Society London, Zoology 30:42-44.

Paulian de Félice, L. 1941. Oniscoïdes de la côtes occidentale d'Afrique. III. Eubelidae. Bulletin de la Société Zoologique de France 66:50-56.

Paulian de Félice, L. 1944. Les oniscoides de la Guyane Française. Revue Française d'Entomologie 10:142-145.

Pearse, A. 1917. Isopoda collected by the Bryant Walker Expedition to British Guiana, with notes on Crustacea from other localities. Occasional Papers of the Museum of Zoology of University of Michigan 46:1-8.

PeCK, S. B. 1970. The terrestrial arthropod fauna of Florida caves. Florida Entomologist 54:203-207.

QuAdRos, A. F. 2010. Os isópodos terrestres são boas ferramentas para monitorar e restaurar áreas impactadas por metais pesados no Brasil? Oecologia Australis 14:569-583.

Quadros, A. F. \& ARAujo, P. B. 2007. Ecological traits of two neotropical oniscideans (Crustacea: Isopoda). Acta Zoologica Sinica 53:241-249.

Quadros, A. F. \& Araujo, P. B. 2008. An assemblage of terrestrial isopods (Crustacea) in southern Brazil and its contribution to leaf litter processing. Revista Brasileira de Zoologia 25:58-66.

Quadros, A. F.; Caubet, Y. \& Araujo, P. B. 2009. Life history comparison of two terrestrial isopods in relation to habitat specialization. Acta Oecologica 35:243-249.

RichaRDSON, H. 1901. Key to the isopods of the Atlantic coast of North America, with descriptions of new and little-known species. Proceedings of the United States National Museum 23:493-579.

RichardSON, H. 1905. A monograph on the isopods of North America. Bulletin of the United States National Museum 54:583-717.

RichardSON, H. 1912. Description of a new terrestrial isopod belonging to the genus Cubaris from Panama. Proceedings of the United States National Museum 42:477-479.
SCHMALFuss, H. 1978. Morphology and function of cuticular micro-scales and corresponding structures in terrestrial isopods (Crust., Isop., Oniscoidea). Zoomorphologie 91:263-274.

SCHMALFUSs, H. 1998. Evolutionary strategies of the antennae in terrestrial isopods. Journal of Crustacean Biology 18:10-24.

SCHMALFuss, H. 2003. World catalog of terrestrial isopods (Isopoda: Oniscidea). Stuttgarter Beiträge zur Naturkunde 654:1-341.

Schmalfuss, H. \& FerRara, F. 1983. Terrestrial isopods from West Africa, Part 3: family Armadillidae Verhoeff, 1917. Monitore Zoologico Italiano, Nuova Serie, Supplemento 18:111-157.

Schmidt, C. 2002. Contribution to the phylogenetic system of the Crinocheta (Crustacea, Isopoda). Part 1 (Olibrinidae to Scyphacidae s. str.). Mitteilungen aus dem Museum für Naturkunde in Berlin 78:275-352.

Schmidt, C. 2003. Contribution to the phylogenetic system of the Crinocheta (Crustacea, Isopoda). Part 2 (Oniscoidea to Armadillidiidae). Mitteilungen aus dem Museum für Naturkunde in Berlin 79:3-179.

SchMIDT, C. 2007. Revision of the Neotropical Scleropactidae (Crustacea: Oniscidea). Zoological Journal of the Linnean Society 151:1-339.

Schmidt, C. \& Leistikow, A. 2005. Review of the genus Androdeloscia Leistikow, with description of four new species (Crustacea: Isopoda: Oniscidea). Entomologische Abhandlungen 62(2):117-163.

SCHMÖLZER, K. 1974. Landisopoden aus Zentral- und Ostafrika (Isopoda, Oniscoidea). Sitzungsberichte der österreichischen Akademie der Wissenschaften, mathematischnaturwissenschaftliche Klasse, Abteilung I 182:147-200.

Schultz, G. A. 1961. Cubaris murina Brandt, an isopod crustacean new to the United States. Crustaceana 3(2):169-170.

Schultz, G. A. 1962. Miktoniscus grayi, a new species of terrestrial isopod Crustacea from North Carolina. Journal of the Elisha Mitchell Scientific Society 78(1):47-51.

Schultz, G. A. 1963. Trichorhina donaldsoni, new species, a terrestrial isopod crustacean from Florida. American Midland Naturalist 69(2):435-440

Schultz, G. A. 1964. Philoscia bonita, a new species of isopod crustacean from Florida. American Midland Naturalist 71(1):156-160.

Schultz, G. A. 1973. The cavernicolous fauna of Hawaiian lava tubes, 2. Two new genera and species of blind isopod crustaceans (Oniscoidea: Philosciidae). Pacific Insects 15(1):153-162.

Schultz, G. A. 1976. MIktoniscus halophilus Blake, M. medcofi (Van Name) and M. morganensis n. comb., reconsidered with notes on New World species of the genus (Crustacea, Isopoda, Trichoniscidae). American Midland Naturalist 95(1):28-41.

Schultz, G. A. 1995. Terrestrial isopod crustaceans (Oniscidea) from Paraguay with definition of a new family. Revue Suisse de Zoologie 102(2):387-424.

Schultz, G. A. \& Johnson, C. 1984. Terrestrial isopod crustaceans from Florida (Oniscoidea). Tylidae, Ligiidae, Halophilosciidae, Philosciidae, and Rhyscotidae. Journal of Crustacean Biology 4(1):154-171.

Silva, M. S. \& Ferreira, R. L. 2015. Cave invertebrates in Espírito Santo state, Brazil: a primary analysis of endemism, threats and conservation priorities. Subterranean Biology 16:79-102.

Sokolowicz, C. C.; Araujo, P. B. \& Boelter, J. F. 2008. A new species of Benthana (Crustacea: Isopoda: Philosciidae) from southern Brazil. Revista Brasileira de Zoologia 25(2):314-318.

Souza, L. A.; AraúJo, J. P. \& Campos-Filho, I. S. 2011. The genus Trichorhina Budde-Lund in Brazil, with description of seven new species (Isopoda, Oniscidea, Platyarthridae). Iheringia, Série Zoologia 101(3):239-261.

Souza, L. A.; Bezerra, A. V. \& AraúJo, J. P. 2006. The first troglobitic species of Scleropactidae from Brazil (Crustacea, Isopoda, Oniscidea). Subterranean Biology 4:37-43.

Souza, L. A.; Ferreira, R. L. \& Senna, A. R. 2015. Amphibious shelterbuilder Oniscidea species from the New World with description of a new subfamily, a new genus and a new species from Brazilian Cave (Isopoda, Synocheta, Styloniscidae). PLoS ONE 10(5):e0115021.

Souza, L. A. \& Lemos de Castro, A. 1991. The genus Circoniscus Pearse, 1917 in Brazil, with a description of three new species (Isopoda Oniscidea Scleropactidae). Tropical Zoology 4(1):45-64.

Souza, L. A.; Senna, A. R. \& KurY, A. B. 2010. A new species and firs record of Gabunillo Schmalfuss \& Ferrara, 1983 (Isopoda, Oniscidea, Armadillidae) from the Neotropics. Zootaxa 2677:1-14. 
SouZA-Kury, L.A. 1997. Two new species of Trichorhina from Brazilian Amazonia (Isopoda, Oniscidea, Platyarthridae). Crustaceana 70:180190.

SouzA-Kury, L.A. 1998. Malacostraca. Peracarida. Isopoda. Oniscidea. In: Young, P. ed. Catalogue of Crustacea of Brazil. Rio de Janeiro, Museu Nacional, p. 653-674.

Strouhal, H. 1961. Die Oniscoideen-Fauna der Juan Fernández-Inseln (Crustacea, Isopoda terrestria). Annalen des Naturhistorischen Museums in Wien 64:185-244.

TAiti, S. \& Ferrara, F. 1980. The family Philosciidae (Crustacea Oniscoidea) in Africa, South of the Sahara. Monitore Zoologico Italiano 4, N.S., Supplemento 13:53-98.

TAITI, S. \& Ferrara, F. 1982. Revision of the family Philosciidae (Crustacea, Isopoda, Oniscoidea) from South Africa. Annals of the South African Museum 90(1): 1-48.

TAIti, S. \& Ferrara, F. 1983. Su alcuni isopodi terrestri della Réunion, di Mauritius e delle Seychelles. Revue Suisse de Zoologie 90:199-231.

Taiti, S. \& Ferrara, F. 1987. Contributions to the knowledge of the mountain fauna of Malawi. 6. Terrestrial isopods (Crustacea). Revue de Zoologie Africaine 101:69-102.

Taiti, S. \& Ferrara, F. 1991. Two new species of terrestrial Isopoda (Crustacea, Oniscidea) from Ascension Island. Journal of Natural History 25:901-916.

TAITI, S.; FERrARA, F. \& KwON, D. 1992. Terrestrial Isopoda from the Togian Islands, Sulawesi, Indonesia. Invertebrate Taxonomy 6:787-842.

Taiti, S.; Ferrara, F. \& Schmalfuss, H. 1986. Chileoniscus marmoratus gen. et sp. n. from Chile (Oniscidea, Scleropactidae). Annales Historico-Naturales Musei Nationalis Hungarici 78:63-69.

TAITI, S. \& HowARTH, F. 1996. Terrestrial isopods (Crustacea, Oniscidea) from Hawaiian caves. Mémoires de Biospéologie 24:97-118.

TAiti, S.; PaOli, P. \& Ferrara, F. 1998. Morphology, biogeography, and ecology of the family Armadillidae (Crustacea, Oniscidea). Israel Journal of Zoology 44:291-301.

VANDEL, A. 1948. Les isopodes volvationnels exoantennés et la genèse de leurs coaptations. Bulletin Biologique de la France et de la Belgique 82: $388-428$

VANDEL, A. 1933. Liste des espèces de Trichoniscidae (crustacés - isopodes) signalées jusqu'ici en France. Archives de Zoologie Expérimentale et Générale 75:35-54.

VANDEL, A. 1952. Les trichoniscides (crustacés - isopodes) de l'hémisphère austral. Mémoires du Muséum National d'Histoire Naturelle 6:1-116.

VANDEL, A. 1960. Isopodes terrestres (Première Partie). In: FÉDÉRATION Française des Sociétes de Sciences Naturelles, ed. Faune de France 64. Paris, Lechevalier, p. 1-416.

VAndel, A. 1962. Isopodes terrestres (Deuxième Partie). In: Fédération Française des Sociétes de Sciences Naturelles, ed. Faune de France 66. Paris, P. Lechevalier, p.417-931.

VANDEL, A. 1963. Isopodes terrestres recueillis en Amerique du Sud par Claude Delamare Deboutteville. In: Debouteville, C. D. \& RAPoport, E. H. eds. Biologie de l'Amerique Austral. Paris, CNRS, CNIT. vol. 2, p.63-100.
VANDEL, A. 1965. Les "Trichoniscidae" cavernicoles (Isopoda terrestria; Crustacea) de l'Amérique du Nord. Annales de Spéléologie 20:347-389.

VANDEL, A. 1968. Isopodes terrestres. In: Institut Royal DES SCIENCES De Belgique, ed. Mission Zoologique Belge aux Îles Galapagos et en Ecuador (N. et J. Leleup, 1964-65). Brussels, Musee Royale l'Afrique Centrale. vol. 1, p.37-168.

VANDEL, A. 1977. La faune terrestre de l'Île de Sainte-Hélène. 4me partie. 1. Isopodes terrestres. Annales du Musée Royal de l'Afrique Centrale, Sciences Zoologiques 220:385-426.

VAn Name, W. G. 1920. Isopods collected by the American Museum Congo Expedition. Bulletin of the American Museum of Natural History 43:41-108.

Van Name, W. G. 1925. The isopods of Kartabo, Bartica District, British Guiana. Zoologica 6:461-503.

VAN NAME, W. G. 1936. The American land and freshwater isopod Crustacea. Bulletin of the American Museum of Natural History 71:1-535.

VAN NAme, W. G. 1940. A supplement to the American land and freshwater isopod Crustacea. Bulletin of the American Museum of Natural History 77:109-142.

Van Name, W. G. 1942. A second supplement to the American land and freshwater isopod Crustacea. Bulletin of the American Museum of Natural History 80:299-329.

VerhoefF, K. W. 1928. Über einige Isopoden der Zoologischen Staatssammlung in München. Zoologischer Anzeiger 76:25-36, 113-123.

VerhoefF, K. W. 1942. Äthiopische Isopoda terrestria der Hamburger Zoologischen Museums. Zoologischer Anzeiger 140:1-163.

Vilela, E.; Kudo, H. \& Loureiro, M. 1971. Oniscoides de Dourados, Estado de Mato Grosso. Seiva 31:183-189.

Wood, C. T.; KostanjŠEka, R.; Araujo, P. B. \& Štrus, J. 2017. Morphology, microhabitat selection and life-history traits of two sympatric woodlice (Crustacea: Isopoda: Oniscidea): a comparative analysis. Zoologischer Anzeiger 268:1-10

Wood, C. T.; Schlindwein, C. C. D.; Soares, G. L. G. \& Araujo, P. B. 2012. Feeding rates of Balloniscus sellowii (Crustacea, Isopoda, Oniscidae): the effect of leaf litter decomposition and its relation to the phenolic and flavonoid content. Zookeys 176:231-245.

ZimmermanN, B. L.; Almerão, M. P.; Bouchon, D. \& Araujo, P. B. 2012. Detection of Wolbachia (Alphaproteobacteria: Rickettsiales) in three species of terrestrial isopods (Crustacea: Isopoda: Oniscidea) in Brazil. Brazilian Journal of Microbiology 43(2):711-715.

Zimmermann, B. L.; Bouchon, D.; Almerão, M. P. \& Araujo, P. B. 2015b. Wolbachia in Neotropical terrestrial isopods. FEMS Microbiology Ecology 91(4):fiv025.

Zimmermann, B. L.; Campos-Filho, I. S.; Deprá, M. \& Araujo, P. B. 2015a. Taxonomy and molecular phylogeny of the Neotropical genus Atlantoscia (Oniscidea, Philosciidae): DNA barcoding and description of two new species. Zoological Journal of the Linnean Society 174:702-717 